\title{
WestVirginiaUniversity
}

THE RESEARCH REPOSITORY @ WVU

Graduate Theses, Dissertations, and Problem Reports

2010

\section{Pot heat balance analysis in continuous galvanizing lines}

Quang Minh Phuong
West Virginia University

Follow this and additional works at: https://researchrepository.wvu.edu/etd

\section{Recommended Citation}

Phuong, Quang Minh, "Pot heat balance analysis in continuous galvanizing lines" (2010). Graduate Theses, Dissertations, and Problem Reports. 2181.

https://researchrepository.wvu.edu/etd/2181

This Thesis is protected by copyright and/or related rights. It has been brought to you by the The Research Repository @ WVU with permission from the rights-holder(s). You are free to use this Thesis in any way that is permitted by the copyright and related rights legislation that applies to your use. For other uses you must obtain permission from the rights-holder(s) directly, unless additional rights are indicated by a Creative Commons license in the record and/ or on the work itself. This Thesis has been accepted for inclusion in WVU Graduate Theses, Dissertations, and Problem Reports collection by an authorized administrator of The Research Repository @ WVU. For more information, please contact researchrepository@mail.wvu.edu. 


\title{
POT HEAT BALANCE ANALYSIS IN CONTINUOUS GALVANIZING LINES
}

\author{
Quang Minh Phuong \\ Thesis submitted to the \\ College of Engineering and Mineral Resources \\ at West Virginia University \\ in partial fulfillment of the requirements \\ for the degree of \\ Master of Science \\ in \\ Industrial Engineering \\ Bhaskaran Gopalakrishnan, Ph.D., Chair \\ Robert Creese, Ph.D. \\ Xingbo Liu, Ph.D. \\ Frank Goodwin, Ph.D.
}

Department of Industrial and Management Systems Engineering

Morgantown, West Virginia

2010

Keywords: Galvanizing, Pot, Heat balance

Copyright 2010 Quang M. Phuong 


\section{ABSTRACT \\ Pot Heat Balance Analysis for \\ Continuous Galvanizing Lines \\ Quang Minh Phuong}

Galvanizing is an energy intensive industry. Knowing how much energy is consumed when producing a certain product will help the company in determining which products can be produced to maximize profits. E-GEPDSS was built to explore the potential of saving energy in galvanizing lines by utilizing heat balance analysis. Heat transfer mechanisms of the heat losses for the pot presented in the heat balance are basic heat transfer concepts (i.e. radiation, convection, conduction, and specific heat.

The pot heat balance model was built and applied using the data collected from a host company during the plant visit. Sensitivity analyses were done to study the impact of changing values of input parameters on the total heat loss of main pot and pre-melt pot during the production as well as downtime (for the main pot).

The model was run and results were obtained and discussed. When there is no pre-melt pot, the largest heat loss is the heat required to melt ingots and maintain pot temperature. When there is a pre-melt pot in the process, the largest heat loss in the main pot is the heat loss from zinc coating. Heat losses from the surface, walls, air knife cooling effect, and steel strip are significant. Heat losses from the bottom and dross removal seem not to be significant. Emissivity, dimensions of the pot, temperature of the pot, and strip entry temperature have significant impact on the total heat loss. Total heat loss is most sensitive to changes of one of these parameters. Ambient temperature, thermal conductivity and wiping gas temperature do not have very much significant impact on the total heat loss. Total heat loss is not really sensitive to changes of one of these parameters. In the future, the model will be applied extensively to more galvanizing lines in order to help the galvanizers to have a more understanding about the energy consumption when producing their products. 


\section{Acknowledgement}

I would like to give my foremost thanks to Dr. Gopala for his valuable advice and constant support during the whole time of this research work. Without him, this thesis would not be successful.

I would also like to acknowledge International Lead Zinc Research Organization (ILZRO) for funding this research. The funding has made trips to host companies and Galvanized Autobody Partnership (GAP) meetings possible.

I would like to thank to Dr. Frank Goodwin for his being a wonderful mentor and for his constant support.

I would like to extend my thanks to Dr. Creese who has been a great advisor throughout my period of study and research.

I would like to express my gratitude to Dr. Xingbo liu for his advice and insight in the galvanizing industry which have helped a lot in this research.

I would also like to thank Mr. Michel Dubois for his suggestions and feedback to the heat balance equations.

Finally, I would like to thank my parents and brothers for their inspiration, motivation and support throughout my life and study. 


\section{LIST OF FIGURES}

Figure 1: Expected service life to first maintenance (5\% red rust) of iron and steel based on the zinc coating thickness and the environment [15] ............................................... 1

Figure 2: Hot dip galvanizing line [17]................................................................. 5

Figure 3: Schematic of a continuous galvanzing pot [8] .............................................. 8

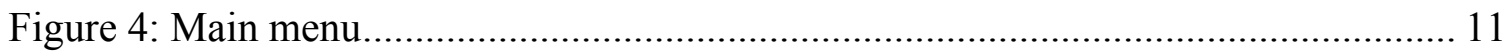

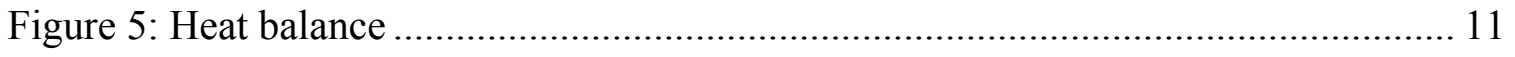

Figure 6: Heat loss from surface ……………………….................................... 12

Figure 7: Heat loss through walls .............................................................................. 13

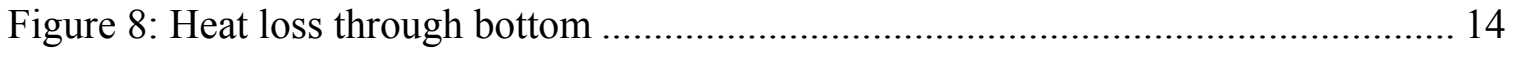

Figure 9: Heat loss to steel strip............................................................................ 15

Figure 10: Heat required to melt ingots and maintain pot temperature ……………....... 16

Figure 11: Heat loss due to air knife cooling effect........................................................ 17

Figure 12: Heat loss from Zn coating .................................................................... 18

Figure 13: Heat loss from dross removal ................................................................... 19

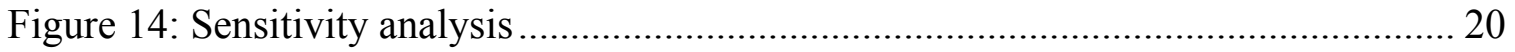

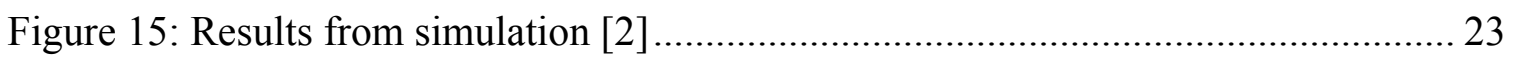

Figure 16: Methodology flowchart .............................................................................. 33

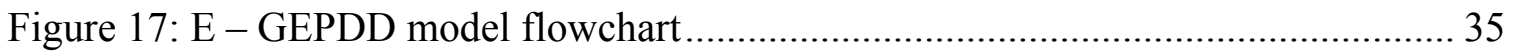

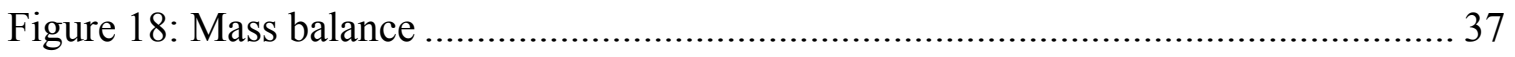

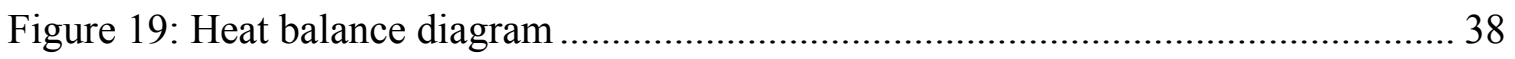

Figure 20: Total heat loss versus Scenarios of different pot dimensions ......................... 67

Figure 21: Total heat loss versus Scenarios of different pot temperatures ........................ 68

Figure 22: Total heat loss versus Scenarios of different ambient temperatures ................ 69

Figure 23: Total heat loss versus Scenarios of different emissivities ................................ 71

Figure 24: Total heat loss versus Scenarios of different thermal conductivities .............. 72

Figure 25: Total heat loss versus Scenarios of different strip entry temperatures............ 74

Figure 26: Total heat loss versus Scenarios of different cooling lengths ......................... 75

Figure 27: Total heat loss versus Scenarios of different wiping gas temperatures........... 77

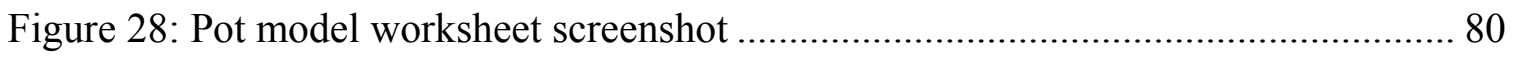

Figure 29: Pot Model worksheet screenshot (cont) ....................................................... 80 


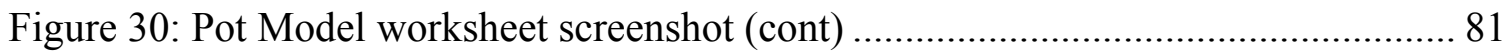

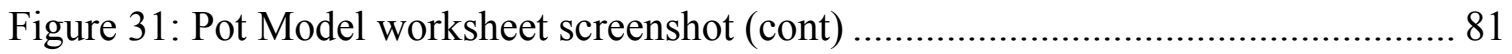

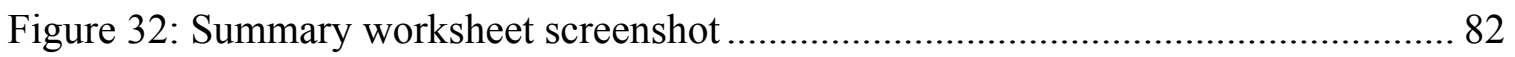

Figure 33: Heat balance worksheet screenshot ........................................................ 82

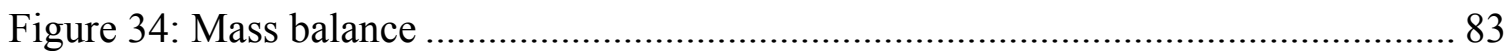

Figure 35: Heat losses' percentages when there is a pre-melt pot ................................ 83

Figure 36: Heat losses' percentages when there is no pre-melt pot............................... 84

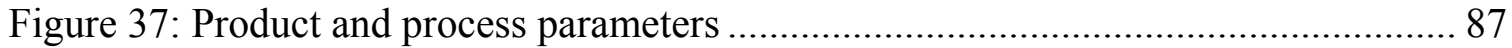

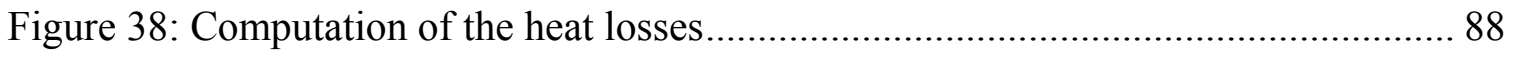

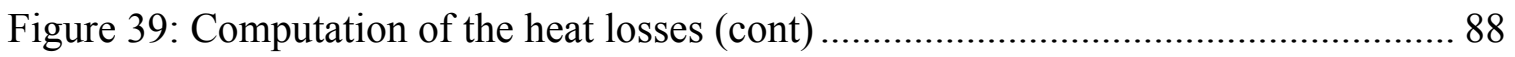

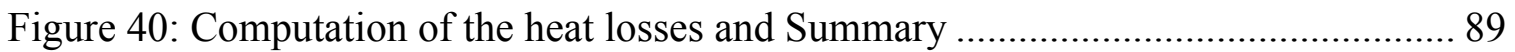

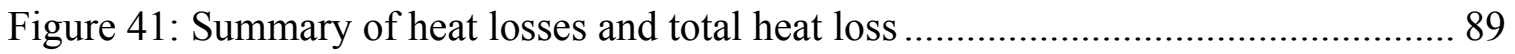

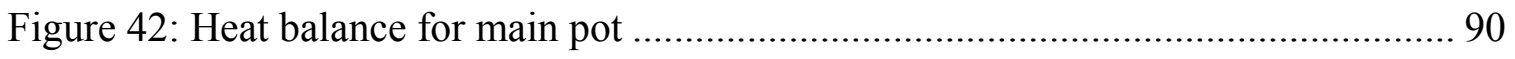

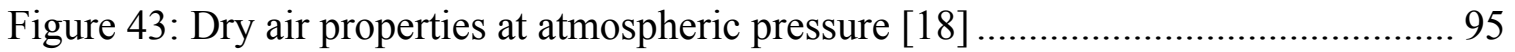

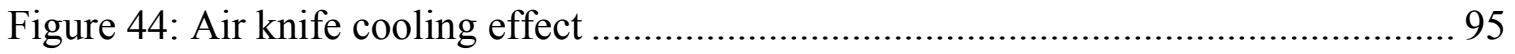

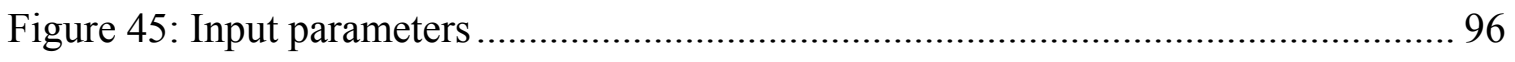

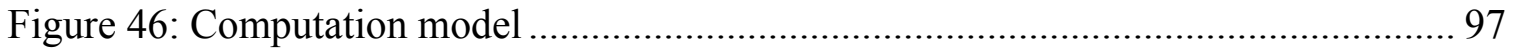

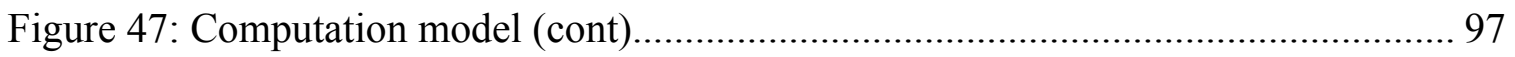

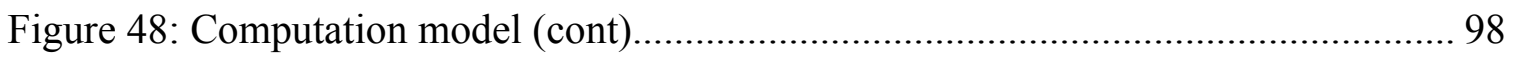

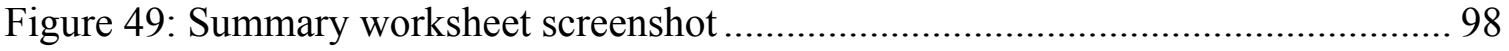

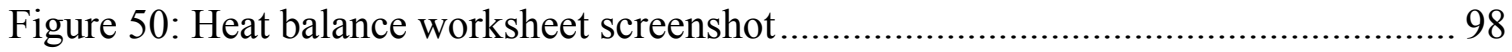

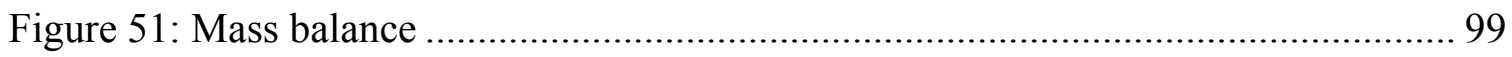

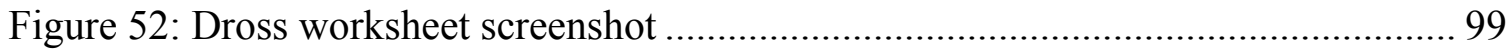

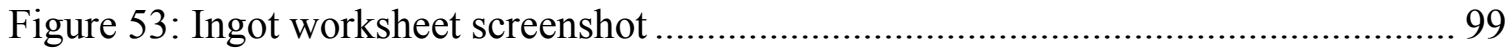

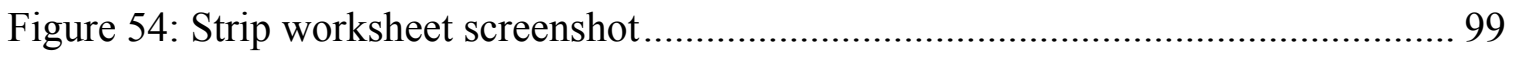

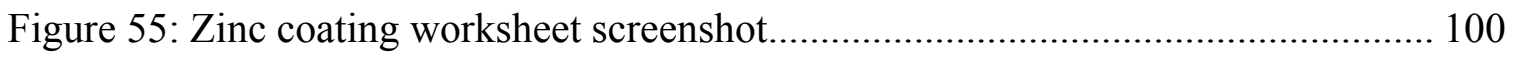

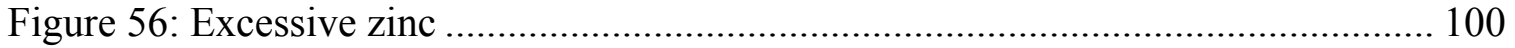

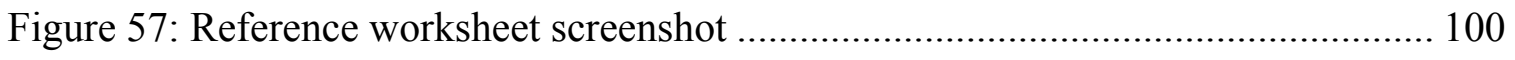

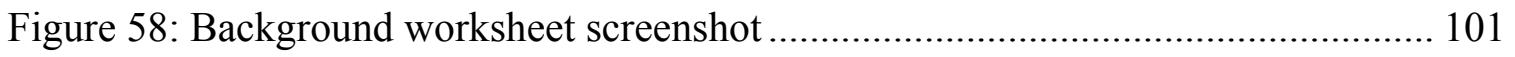

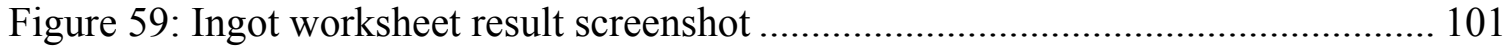

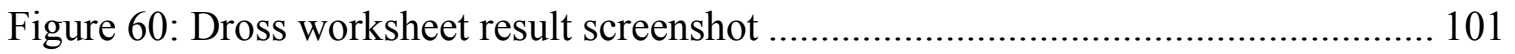


Figure 61: Zinc coating worksheet result screenshot.............................................. 101

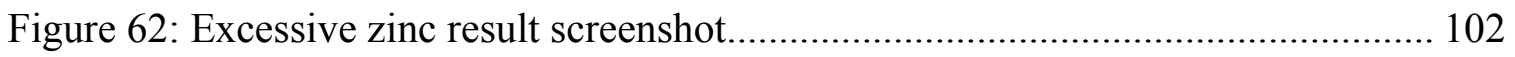

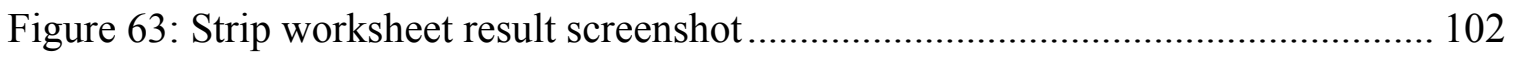

Figure 64: Background worksheet result screenshot ............................................. 102

Figure 65: Reference worksheet result screenshot................................................. 102 


\section{LIST OF TABLES}

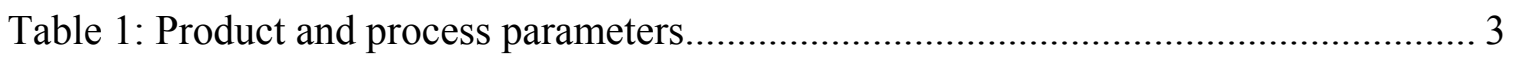

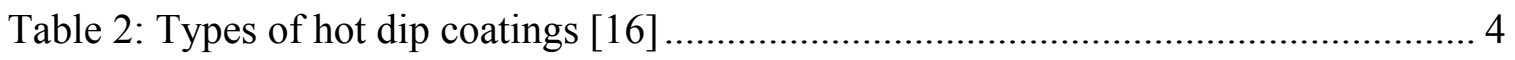

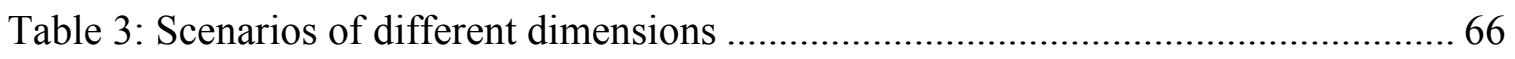

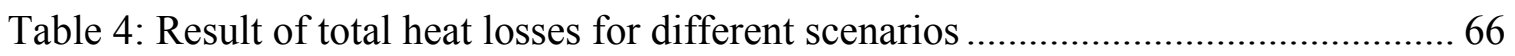

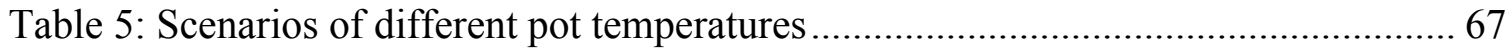

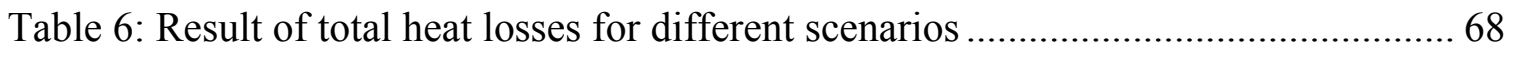

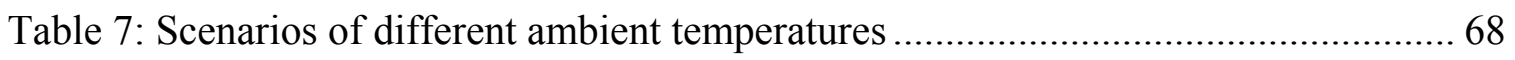

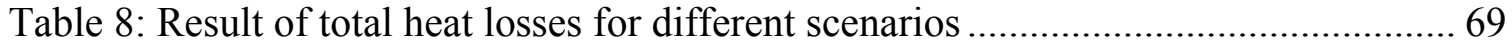

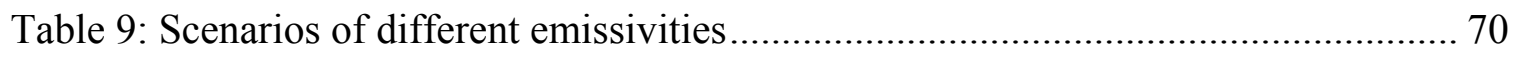

Table 10: Result of total heat losses for different scenarios ........................................ 70

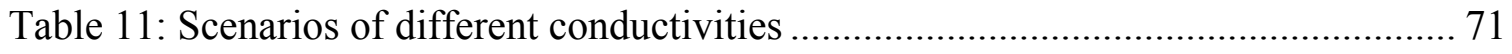

Table 12: Result of total heat losses for different scenarios ....................................... 72

Table 13: Scenarios of different strip entry temperatures.......................................... 73

Table 14: Result of total heat losses for different scenarios ....................................... 73

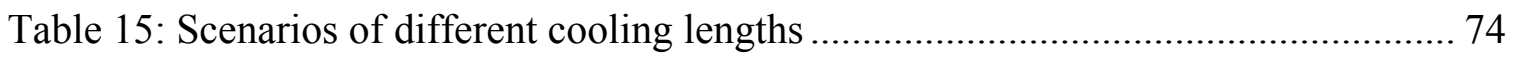

Table 16: Result of total heat losses for different scenarios ....................................... 75

Table 17: Scenarios of different wiping gas temperatures......................................... 76

Table 18: Result of total heat losses for different scenarios ....................................... 76

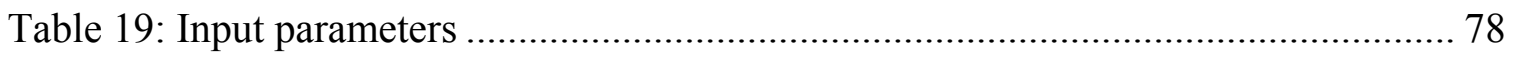

Table 20: Results after running the model ............................................................... 79

Table 21: Coefficients for calculating heat contents of metals ................................... 96 


\section{TABLE OF CONTENTS}

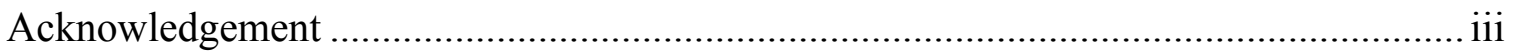

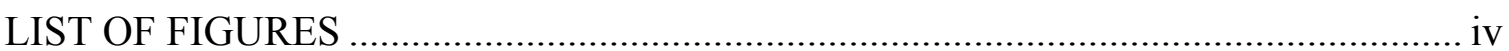

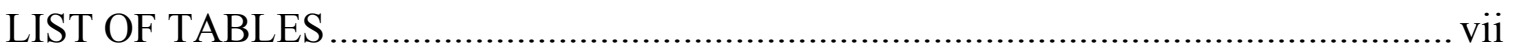

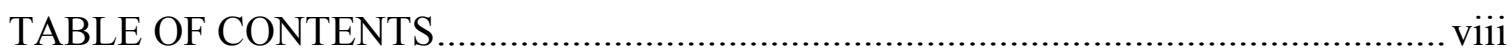

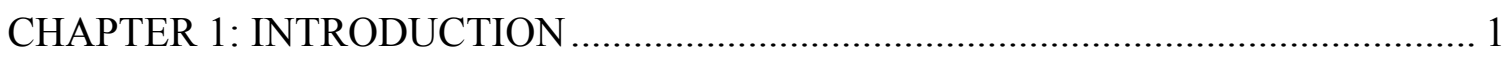

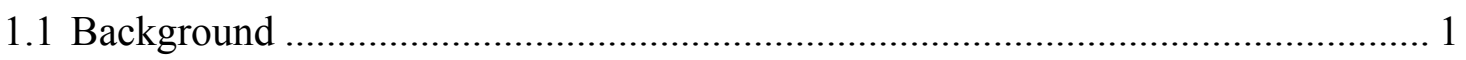

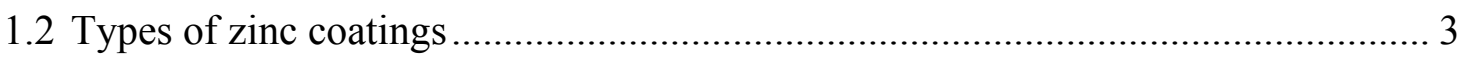

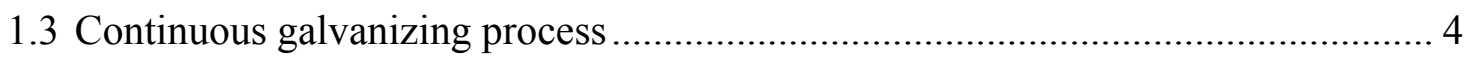

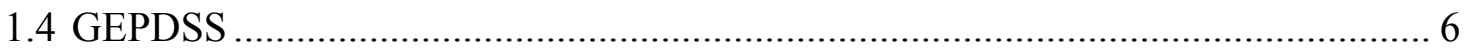

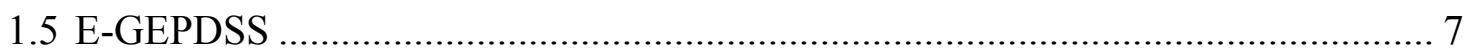

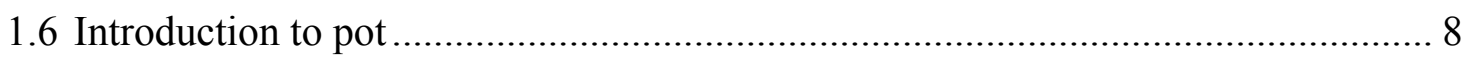

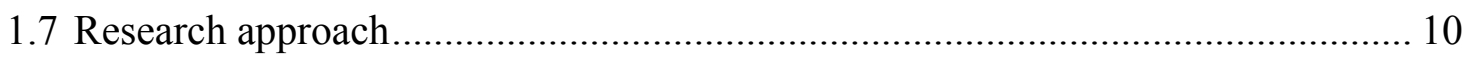

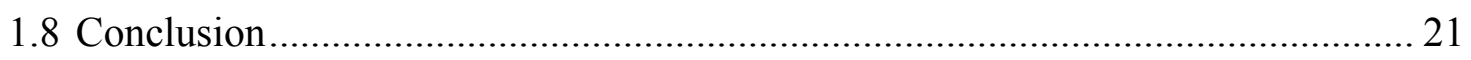

CHAPTER 2: LITERATURE REVIEW …………….............................................. 22

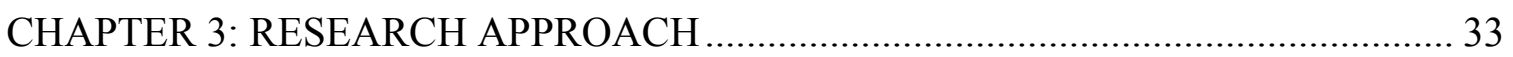

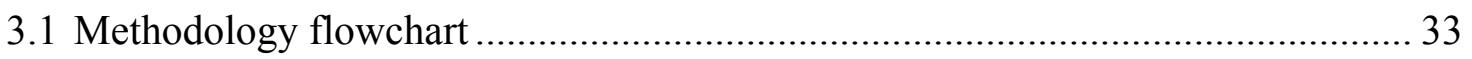

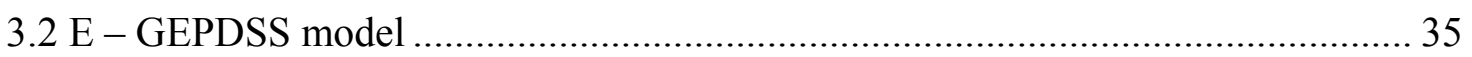

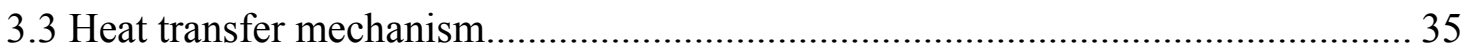

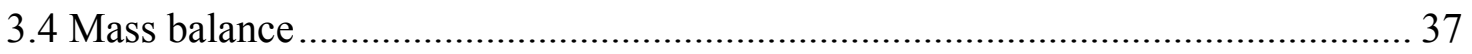

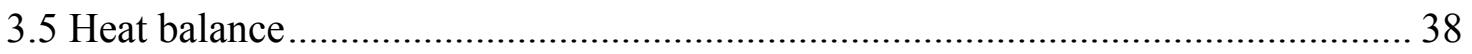

3.5.1 Heat required to melt ingots and maintain the pot temperature...................... 39

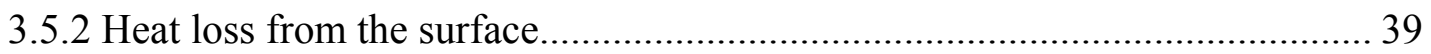

3.5.3 Heat loss through the walls of the pot.......................................................... 42

3.5.4 Heat loss through the bottom by heat conduction............................................. 43

3.5.5 Heat gain/loss from steel strip going through the pot...................................... 44

3.5.6 Heat loss due to air knife cooling effect ........................................................ 44

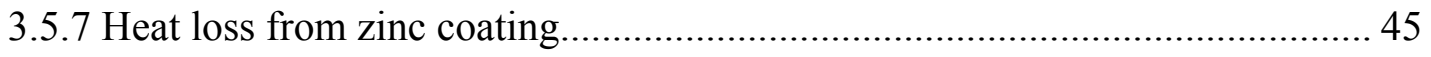

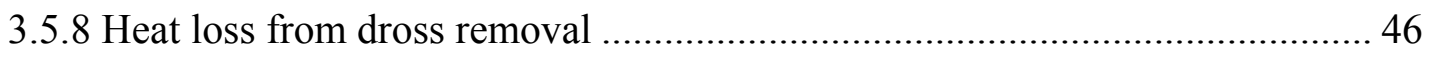

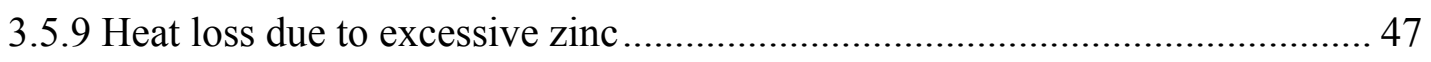

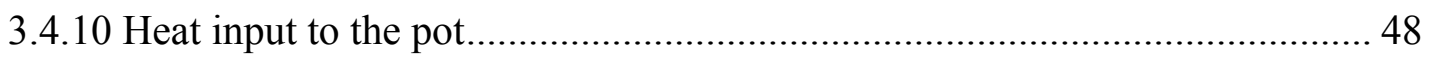

3.5.11 Variations on energy consumption during production and downtime........... 48

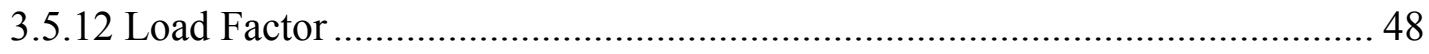

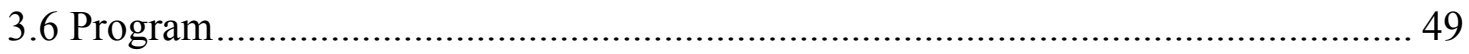




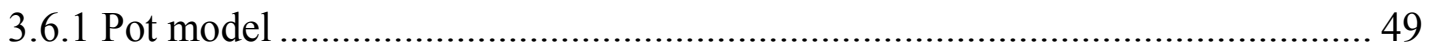

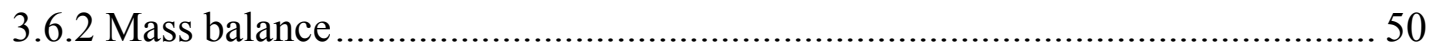

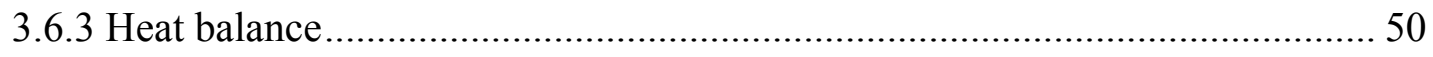

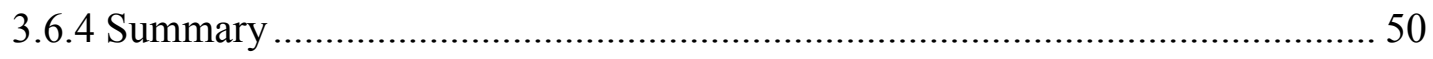

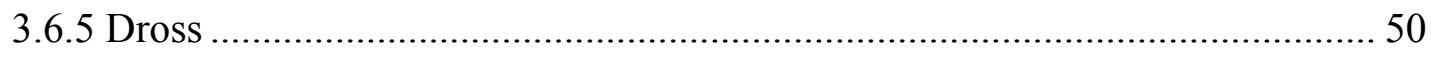

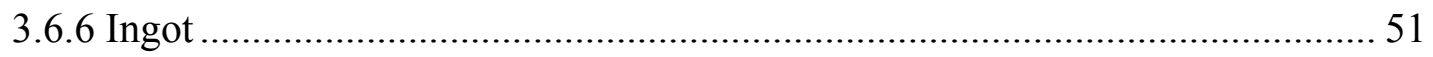

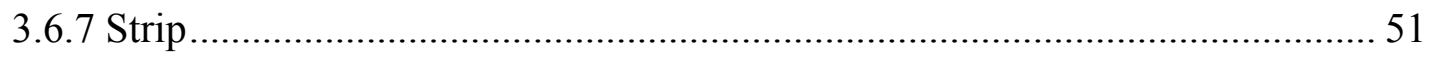

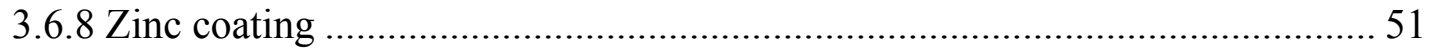

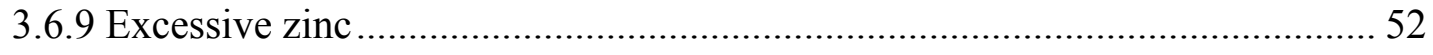

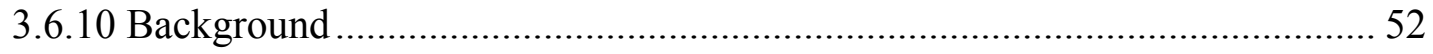

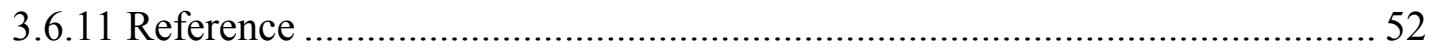

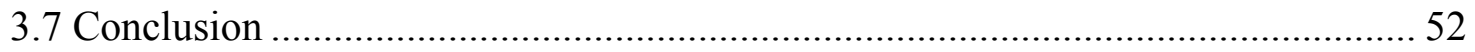

CHAPTER 4: MODEL EXECUTION AND SENSITIVITY ANALYSIS ………......... 53

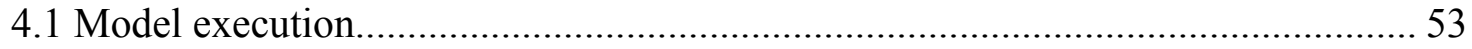

4.1.1 Heat loss from the pot surface ……........................................................ 53

4.1.2 Heat loss through the bottom by heat conduction............................................ 56

4.1.3 Heat loss through the walls of the pot........................................................... 57

4.1.4 Heat absorption/conduction from steel strip .................................................. 58

4.1.5 Heat required to melt ingots and maintain pot temperature.............................. 59

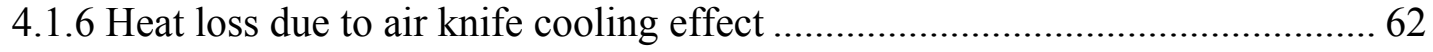

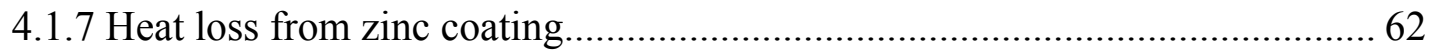

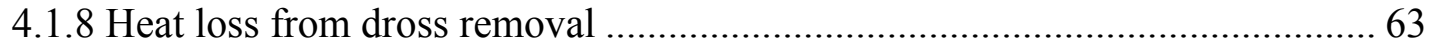

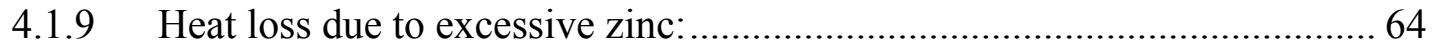

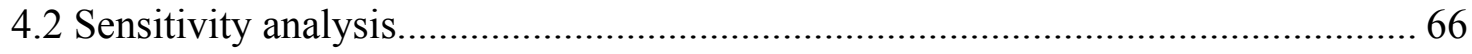

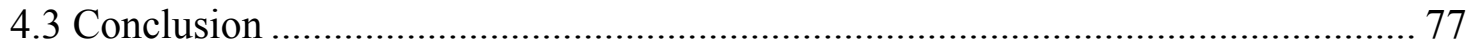

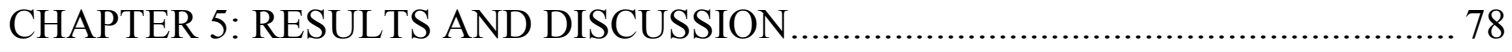

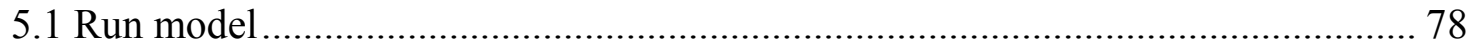

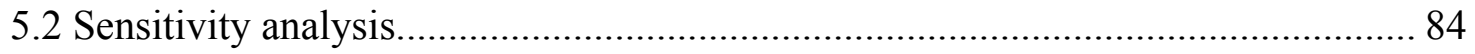

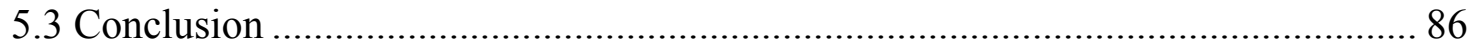

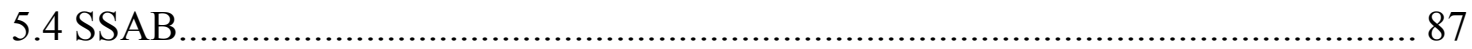

CHAPTER 6: CONCLUSION AND FUTURE WORK ………………………............ 91

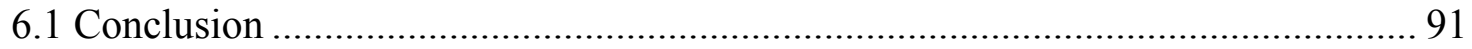

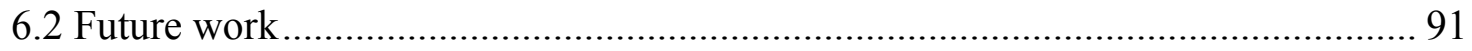

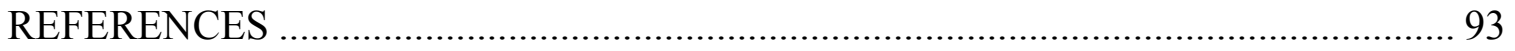




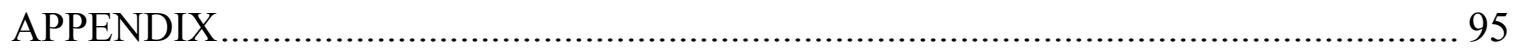

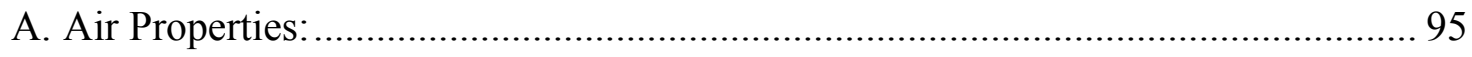

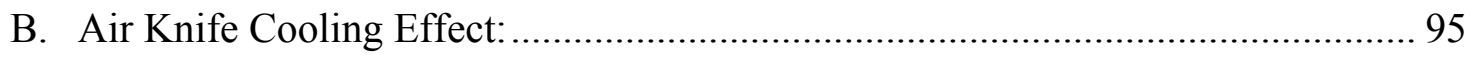

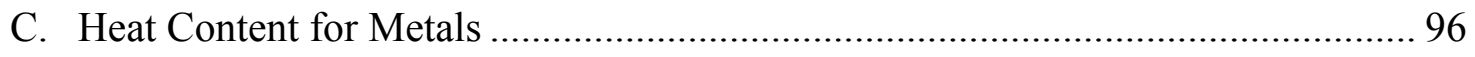

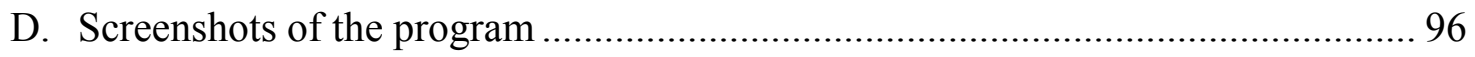




\section{CHAPTER 1: INTRODUCTION}

\subsection{Background}

Corrosion has led to the loss of millions of dollars each year. A large portion of this loss is contributed by the corrosion of iron and steel. It causes structural weakness and disintegration of the metal. Corrosion takes place when metals or alloys are exposed to the moisture in the air. However, metals or alloys can be protected from corrosion by applying a thin layer of zinc coatings on the surface. The graph of expected service life of iron and steel versus zinc coating thickness and environment if zinc coating is applied is shown below.

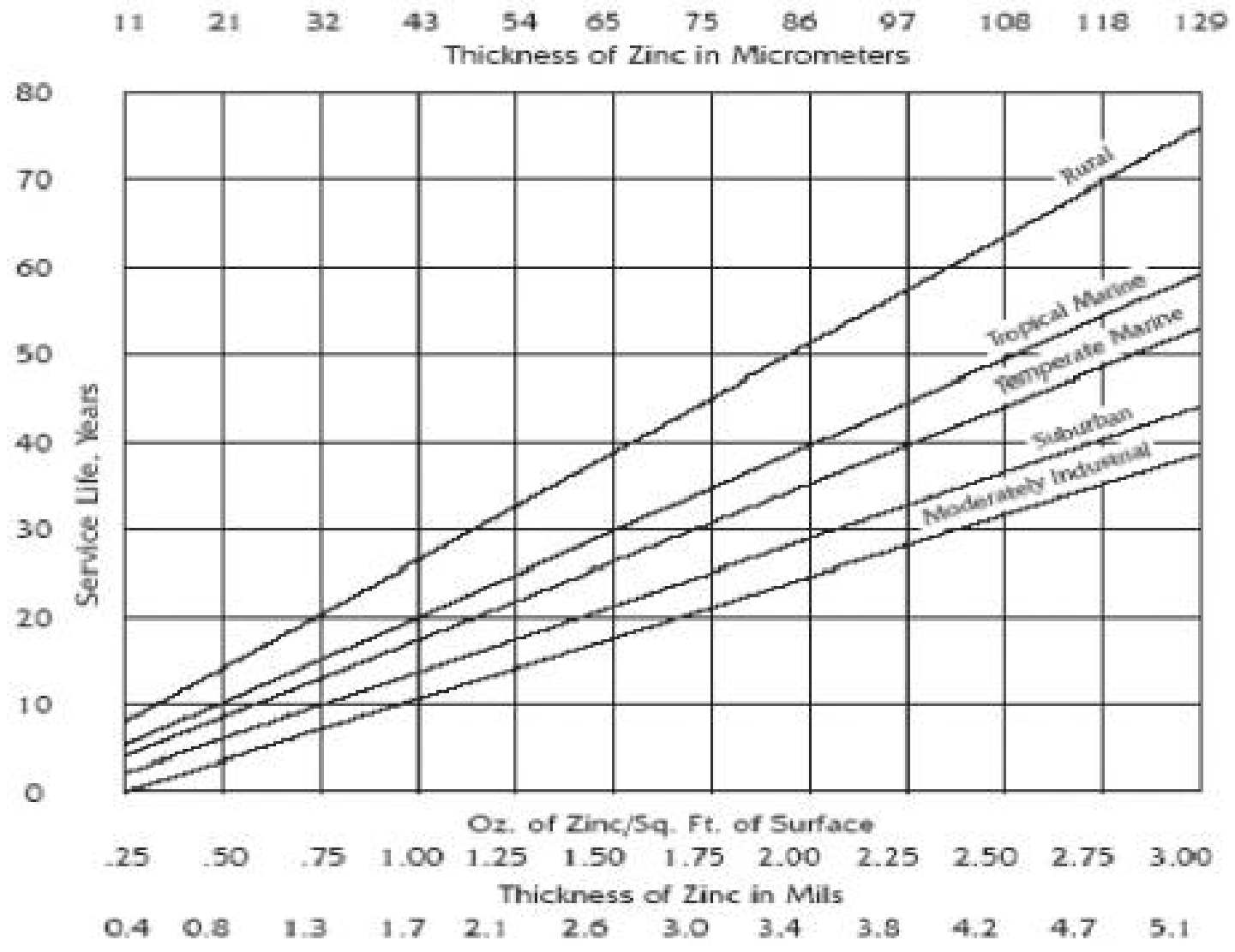

Figure 1: Expected service life to first maintenance (5\% red rust) of iron and steel based on the zinc coating thickness and the environment [15] 
Zinc coating can be applied to steel in two ways: hot dip galvanizing or electrolytic galvanizing. The term general galvanizing is used in which steel strips are dipped in a molten bath of zinc. The term continuous galvanizing is used in which coils of steel are welded end-to-end and then fed continuously through the galvanizing line.

The continuous galvanized process has been introduced and widely used for more than 50 years. There are more than fifty galvanizing lines in the United States. Starting in Europe, lately in Asia, steel makers have invested in a number of high-volume lines that provide high quality steel strip. Galvanizing is the most effective and most popular method of corrosion protection for steel, and the largest field of consumption of zinc. Galvanized steels that possess the formability of steel and corrosion resistance of zinc can be produced at low cost but still provide effective performance. Furthermore, galvanizing for protection of iron and steel is favored because of its ease of application, and the extended maintenance-free service that it provides.

Galvanizing is an energy intensive industry. Profits are reduced because of the increasing cost of energy. Knowing how much energy is consumed when producing a certain product will help the company in determining which products can be produced to maximize profits.

However, little research has been done to study on energy intensity in galvanizing industry. In fact, energy consumption varies with different products. Each product has its own product and process parameter set up which determines how much energy consumed in a particular process.

In this research, the galvanizing pot is the subject of study because it is one of the most energy consuming components in a galvanizing line. Heat balance for the pot can be established to determine amount of energy required for a certain product type while product and process parameters for that product type are inputs for the heat balance model. Below is a short list of typical product and process parameters used in the heat balance. From these parameters, sensitivity analysis can be done to study the variations in energy consumption for various product types. Companies can utilize this sensitivity 
analysis to determine the costs in term of energy and identify the potential for energy savings.

Table 1: Product and process parameters

\begin{tabular}{|c|c|c|}
\hline Product parameter & U.S unit & Metric unit \\
\hline Strip width & $\mathrm{ft}$ & $\mathrm{m}$ \\
\hline Strip thickness & $\mathrm{ft}$ & $\mathrm{m}$ \\
\hline Line speed & $\mathrm{ft} / \mathrm{min}$ & $\mathrm{m} / \mathrm{min}$ \\
\hline Coating weight & ${ }^{\mathrm{oz}} / \mathrm{ft}^{2}$ & $\mathrm{~g} / \mathrm{m}^{2}$ \\
\hline & & \\
\hline Process parameter & & ${ }^{0} \mathrm{C}$ \\
\hline Pot temperature & ${ }^{0} \mathrm{~F}$ & ${ }^{0} \mathrm{C}$ \\
\hline Wiping gas/air temperature & ${ }^{0} \mathrm{~F}$ & ${ }^{2} \mathrm{~m}$ \\
\hline Air knife height & ${ }^{0} \mathrm{ft}$ & ${ }^{0} \mathrm{C}$ \\
\hline Strip's temperature at the entry of the pot & ${ }^{0} \mathrm{~F}$ & \\
\hline
\end{tabular}

\subsection{Types of zinc coatings}

There are some common types of zinc coatings:

Galvanized: A zinc coating, usually hot-dipped. Thick coatings are typically used for heavy outdoor exposure. This coating ranges from a minimum of $0.3 \mathrm{oz} / \mathrm{ft}^{2}$ (or $100 \mathrm{~g} / \mathrm{m}^{2}$ ), up to $0.9 \mathrm{oz} / \mathrm{ft}^{2}$ (or $275 \mathrm{~g} / \mathrm{m}^{2}$ ).

Electrogalvanized: A thinner zinc coating, but applied in a cold, electrolytic pot rather than a molten pot. Examples of application from this coating are hardware components, fasteners, etc.

Galvanneal: A harder and more brittle hot-dip coating with improved paintability. After hot dip process, zinc coated sheet will go through a heat treatment to form a zinc-iron alloy coating.

Galfan: A zinc alloy coating (5\% aluminum) with improved corrosion resistance and formability. 
Galvalume: An aluminum alloy coating (55\% aluminum) with superior corrosion resistance.

Table 2: Types of hot dip coatings [16]

\begin{tabular}{|l|l|l|}
\hline \multicolumn{3}{|c|}{ Types of Hot-Dip Coatings } \\
\hline Coating name & Coating composition & ASTM Specification \\
\hline Galvanize & Zinc & A 653/ A 653M \\
\hline Galvanneal & Zinc - 10\% Iron & A 653/ A 653M \\
\hline Aluminum - Zinc & $55 \%$ Aluminum - Zinc & A 792/A 792M \\
\hline Zinc - Aluminum & Zinc - 5\% Aluminum & A 875/A 875M \\
\hline Zinc -Aluminum - Magnesium & Zn-5/13\% Al- 2/4\% Mg & A 1046/A 1046M \\
\hline Aluminum & Al-5/11\% Si, or pure Al & A 463/A 463M \\
\hline Terne & Lead - 8\% Tin & A 308/A 308M \\
\hline & \multicolumn{2}{|l}{ General requirements for all hot dip coatings - ASTM A 924/A 924M } \\
\hline
\end{tabular}

\subsection{Continuous galvanizing process}

The process detail of a galvanizing line is described below [17].

a) Decoiling: This is the initial phase of the galvanizing line where uncoated steel sheets are loaded. There are typically two decoilers. When one roll is about to end, the trailing end of that roll is welded to the leading end of the second roll. Then, as the second roll is unwound a new roll is kept ready in place of the first roll for processing.

b) Welding: An entry-end welder to join the trailing edge of one coil to the leading edge of the following coil to allow the process to be continuous.

c) Entry Loop: The loop car is situated at the entry end and serves the purpose of maintaining the continuity of the process when there is a change in the decoiler rolls.

d) Annealing Furnace: An annealing furnace is used to heat the steel to high temperatures as it moves to impart the desired mechanical properties (strength and formability) to the steel sheet. 
e) Pot: A bath of molten coating metal being applied to the steel surface.

f) Air knives: Gas knives to wipe of the excess coating metal and obtain the required coating weight.

g) Galvanneal Furnace: Furnace to anneal steel sheet after the pot.

h) Levelling: A tension leveler to flatten the strip to meet the end user requirements.

i) Coiling: A recoiler to rewind the coated coil of steel that now has:

- the desired steel strength and formability

- an adherent, corrosion-resistant coating

- the desired surface finish

- a high level of flatness

- a clear chemical treatment and/or oil to assist with preventing degradation of the coated-sheet appearance

Below is the schematic of a hot-dip coating line.

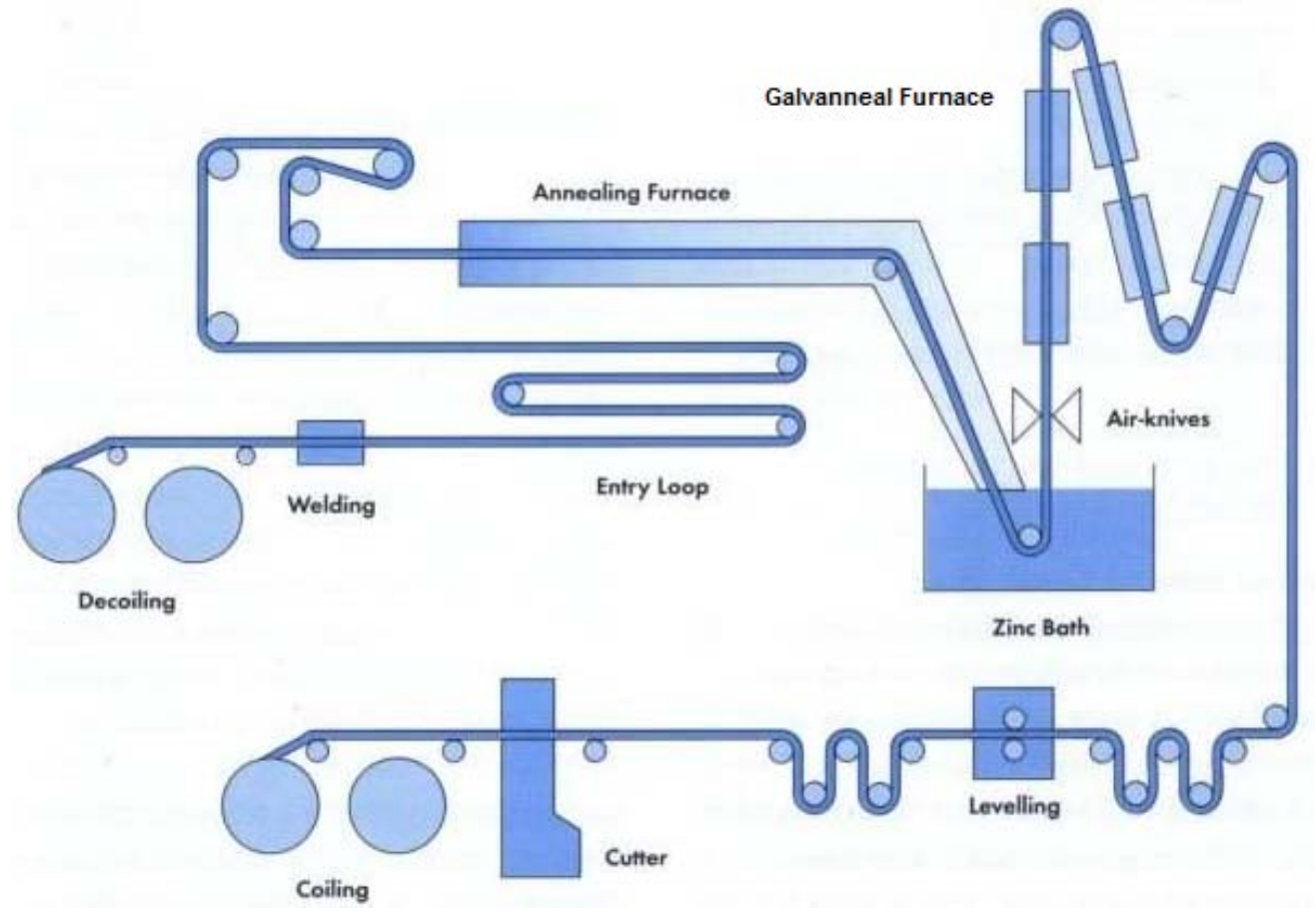

Figure 2: Hot dip galvanizing line [17] 


\subsection{GEPDSS}

GEPDSS was recently developed for modeling a continuous galvanizing line. The research is aimed to quantify the energy consumption in MMBtu/ton of galvanized sheet steel produced and then identify the opportunities for energy conservation.

The model enables users to analyze the impacts of energy saved if they implement any energy savings or efficiency improvement technique on their equipment as well as result of application of new hardware material.

A particular galvanizing line had been applied, and GEPDSS provided approximate energy consumption for that line with $+/-10 \%$ of difference from the actual energy bills.

GEPDSS was developed as a computer-based model to generate energy consumption profile for galvanizing lines. It has a capability of modeling up to three lines in terms of electricity, natural gas, hydrogen, and nitrogen consumption. It has a line diagram which shows snapshot of energy consumption at various points on the line in terms of $\mathrm{MMBtu} / \mathrm{hr}$ and $\mathrm{kW}$ during production and shutdown periods.

GEPDSS is a good tool to analyze energy consumption in a galvanizing line, and how much change in energy consumption if the system is changed for improvements. But in real life, the system is not often changed unless a new technology has been developed. GEPDSS can be used to estimate in advance how much energy that will be consumed if the change is implemented.

GEPDSS is a static simulation of energy consumption of continuous galvanizing line. It does not consider process and system parameters, variations in energy consumption for different products.

GEPDSS does not consider heat loss, which can be calculated to estimate energy consumption. Based on this amount of energy consumption, a company can determine which product to produce to minimize the cost in terms of energy and maximize profit.

Energy consumption can be estimated before installing a new line. Costs to replace machines and equipment are expensive. An effective tool is needed to estimate energy consumption and compare the energy consumptions for various product types. 


\subsection{E-GEPDSS}

E-GEPDSS (Enhanced Galvanizing Energy Profiler Decision Support System) is the enhancement of the GEPDSS. This E-GEPDSS will complement the existing GEPDSS by including process and product parameters and being able to calculate the amount of energy consumption for different products. E-GEPDSS will concentrate intensively on the most energy consuming processes along the galvanizing line (e.g. annealing furnace and pot). Process parameters are set up differently for different products. This leads to different energy consumption and heat losses. Tradeoffs between revenues and costs can be analyzed with the support from sensitivity analysis. Companies can utilize this sensitivity analysis to determine which products consume most energy and examine potential for energy savings.

The objective of E-GEPDSS is to explore the potential of saving energy in galvanizing lines by utilizing heat balance analysis. The specific scope and tasks of this project are listed as follows.

O Heat balance determination in the zinc pot will be accomplished. The characteristics of the pot and product details will be used as input to the model. The various product and process parameters such as line speed, bath chemistry, air knives pressure and temperature will be examined in detail to develop the model.

O The data collected from site visits at our host company (US Steel located in Fairless, PA) are used as an input for the model. Heat balance analysis will be done utilizing this data.

O Development of software to model the pot heat balance. This report is accompanied by the spread sheet models.

This report contains data expressed in US units. The spreadsheet model contains multiplicative conversion factor for determining quantities in metric units from US units. 


\subsection{Introduction to pot}

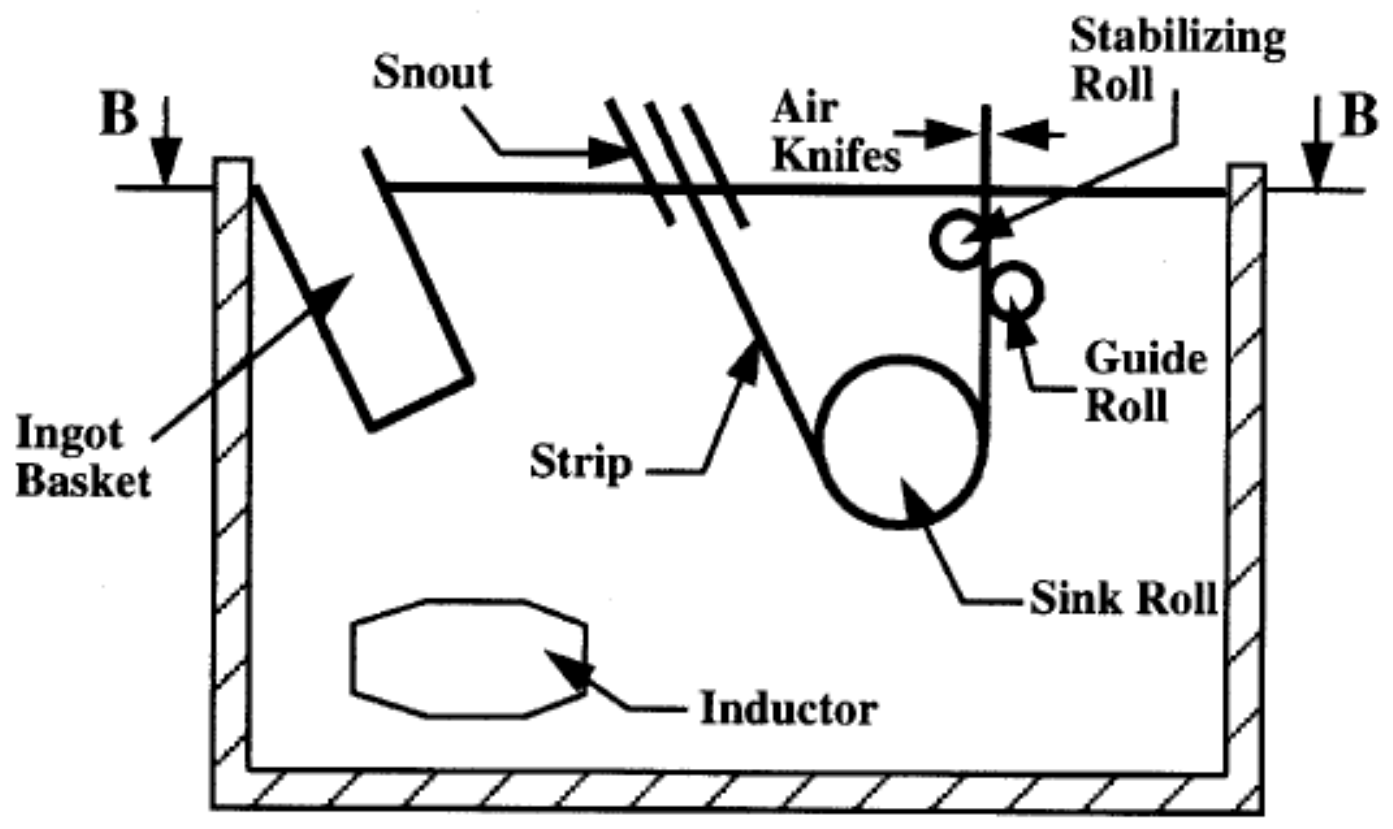

Figure 3: Schematic of a continuous galvanzing pot [8]

At the end of annealing process, the steel strip passes through the snout, and then enters the pot. The steel strip is guided by a sink roll and two stabilizing rolls inside the pot, being immersed in the pot for a few seconds, and then exits the pot. The steel strip passes through an air knife system where excess zinc will be wiped off to obtain the desired coating thickness. Pot temperature is normally $460^{\circ} \mathrm{C}$ and strip temperature is slightly above the pot temperature (e.g. $5^{0} \mathrm{C}$ ). Ingots of $\mathrm{Zn}$-Al alloys are added to the pot to maintain desired bath chemistry and compensate for Zn-Al loss. Several Zn -Al alloy ingots are commercially used, ranging from 4 to $12 \%$ aluminum. Part of the iron dissolved diffuses into the pot where it from intermetallic particles known as dross. Some galvanizing lines have a pre-melt pot to melt ingots into a liquid form before charging them into the main pot. The pre-melt pot is normally free of iron, so the formation of top dross $\left(\mathrm{Fe}_{2} \mathrm{AI}_{5}\right)$ is minimized in the alloying pot.

It is important to have strip surface free of oxide and soils before it enters the pot. The steel - zinc reaction has a significant effect on coating quality of the steel strip. If Fe-Zn intermetallic alloys form, steel strip will have very poor coating adherence. To improve the adherence of zinc coating to the steel trip, aluminum is added to the pot. It was found 
that aluminum if added has a capability to subdue $\mathrm{Fe}-\mathrm{Zn}$ reaction rate, resulting in good quality zinc coating. Added aluminum will act as an inhibitor to $\mathrm{Fe}-\mathrm{Zn}$ reaction at the beginning of immersion. A very thin alloy layer with a composition of $45 \% \mathrm{Al}, 35 \% \mathrm{Fe}$, and $\sim 20 \% \mathrm{Zn}$ is form on the surface of the strip [19].

The dross formation must be kept as low as possible because it implies loss and disturbs the pot stability. Most systems involve some forms of automated handling that remove the pot operator from handling the ingots directly. Reducing variation in zinc temperature is one critical step in reducing the formation of intermetallic compounds $\left(\mathrm{Fe}_{2} \mathrm{Al}_{5}\right)$ or top dross.

\section{a) Pot compositions:}

Typical ranges of percentages of chemicals that contribute to the pot composition are described below [19].

- Total aluminum - typically 0.16 to $0.20 \%$ for galvanize, and 0.11 to $0.14 \%$ for galvanneal.

- Iron (Fe) - typically 0.015 to $0.03 \%$.

- Lead $(\mathrm{Pb})$ - typically zero (0.007\% max); may be up to $0.10 \%$ if a spangle is desired.

- Antimony ( $\mathrm{Sb}$ ) - typically zero; may be up to $0.10 \%$ if a spangle is desired.

- Zinc (Zn) - balance.

NOTE: Most galvanized sheet produced in the western world is spangle-free, i.e., zero $\mathrm{Pb}$ or $\mathrm{Sb}$.

\section{b) Pot and strip temperatures}

- Pot temperatures range from 851 to $878^{\circ} \mathrm{F}$ [455 to $470^{\circ} \mathrm{C}$ ] (typically $865-870^{\circ} \mathrm{F}$ [463 to $\left.\left.465^{\circ} \mathrm{C}\right]\right)[19]$.

- Incoming strip temperature ranges from 797 to $887^{\circ} \mathrm{F}$ [ 425 to $475^{\circ} \mathrm{C}$ ], but no more than $5^{\circ} \mathrm{C}$ above the pot temperature. This supplies just enough heat into the pot so as to minimize the need of inductor power to maintain pot temperature. The pot is more stable when the inductors are not operating [19].

- A good practice of pot management is to avoid zinc temperature fluctuations [19].

- High strip entry temperature can result in more consumption of Al in the solution and more dissolution of the steel strip - leading to more dross generation[19].. 


\section{c) Air knife}

Thickness of the strip is controlled by air knives after it is leaving the pot. It is controlled by adjusting the distance between air blades and the strip, velocity of the air and some other factors depending on how the air knives are constructed.

\section{d) Pot variations}

Pot configurations vary from one galvanizing line to another. The variations could be related to power supply, the air knife wiping system, and the material of the pot and pot insulation. Some galvanizing lines use pre-melt pot to melt ingots before adding them to the pot. Power supply to the pot can be from inductors, electrical grids or natural gas burners. Air knife system uses air or $\mathrm{N}_{2}$ to wipe out excess Zinc on the steel strip surface.

\subsection{Research approach}

\section{a) Heat Balance}

The objective of this research is to study the heat balance of the pot. Energy input, heat losses, and energy output are determined at the detailed. Heat losses through convection, conduction, and radiation through pot components as well as the moving product have been considered.

\section{b) Data collection}

The data collection has been done through plant visits to US Steel (Fairless Works, PA) plant. The data that are used in this report have been modified to protect proprietary information. Extensive data on product, process, and system parameters have been collected during the plant visits.

\section{c) Software}

A computer based model for heat balance will be developed for users.

\section{d) System diagram}

The system diagrams are presented below to describe the process flow of the computer based model. First, users open the program and choose options to proceed such as heat balance or sensitivity analysis. If heat balance option is chosen, users can use the model to compute any type of heat losses that is related to the pot. There are six types of heat losses that contribute to the total energy consumption of the pot, such as heat loss from surface, heat loss through bottom or walls, heat required to melt ingots, heat loss to the 
strip, and heat loss due to air knife cooling effect. Every heat loss has a set of required parameters for input. Output, which is the amount of heat loss, is automatically computed and shown in the model.

If sensitivity analysis option is chosen, user will be able to analyze the variations in energy consumption for different product types by entering different sets of product and process parameters to the model.

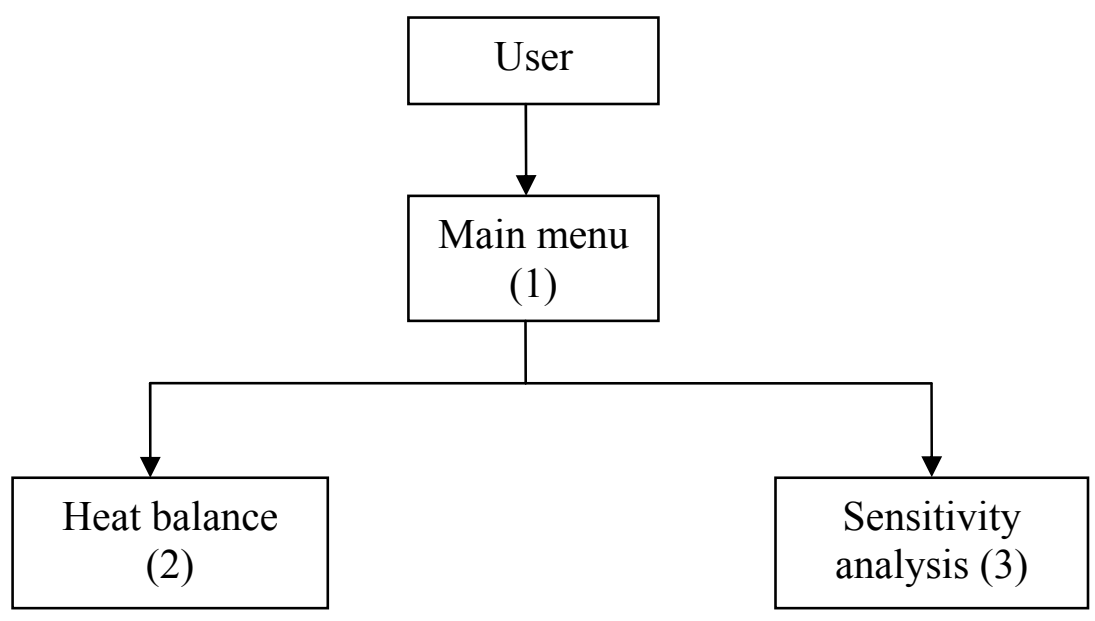

Figure 4: Main menu

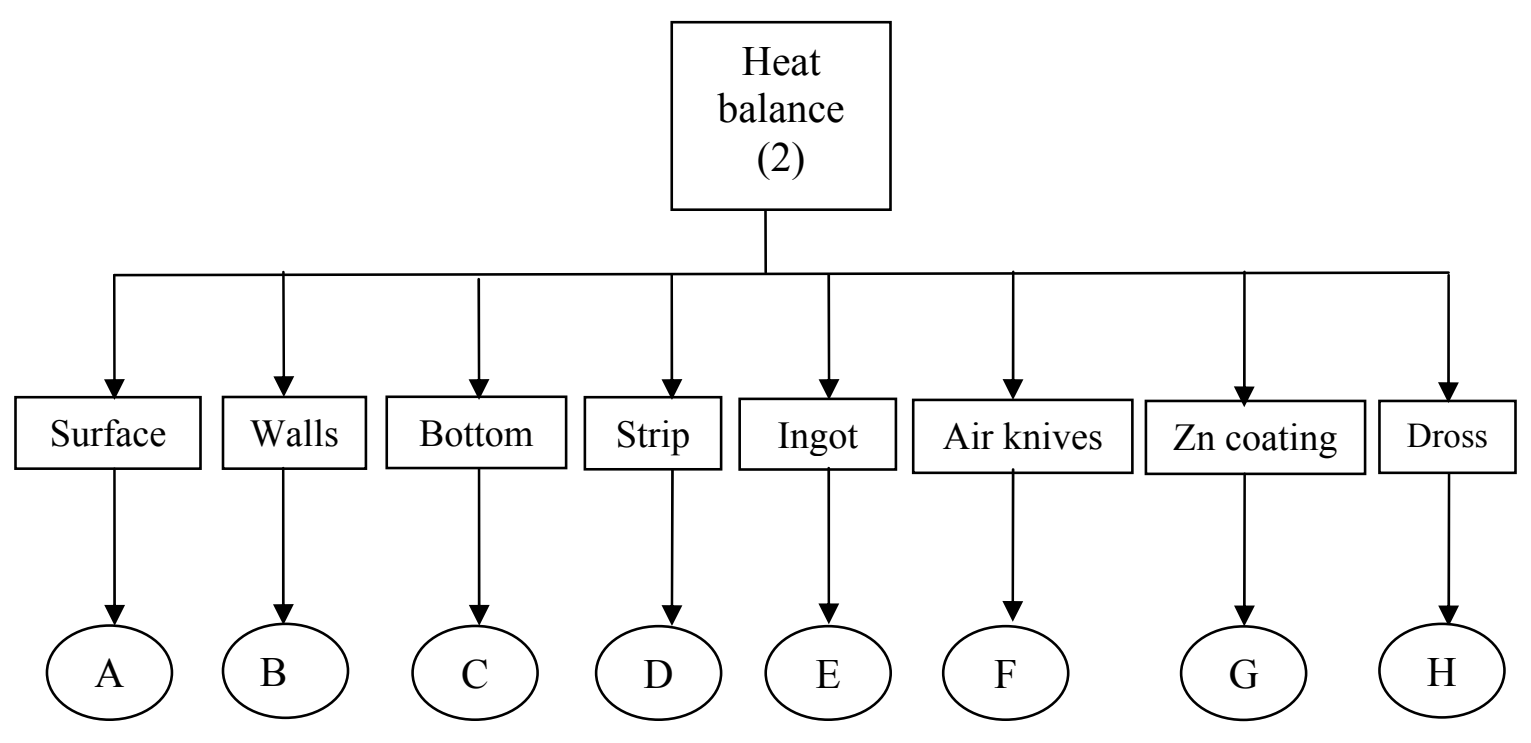

Figure 5: Heat balance 


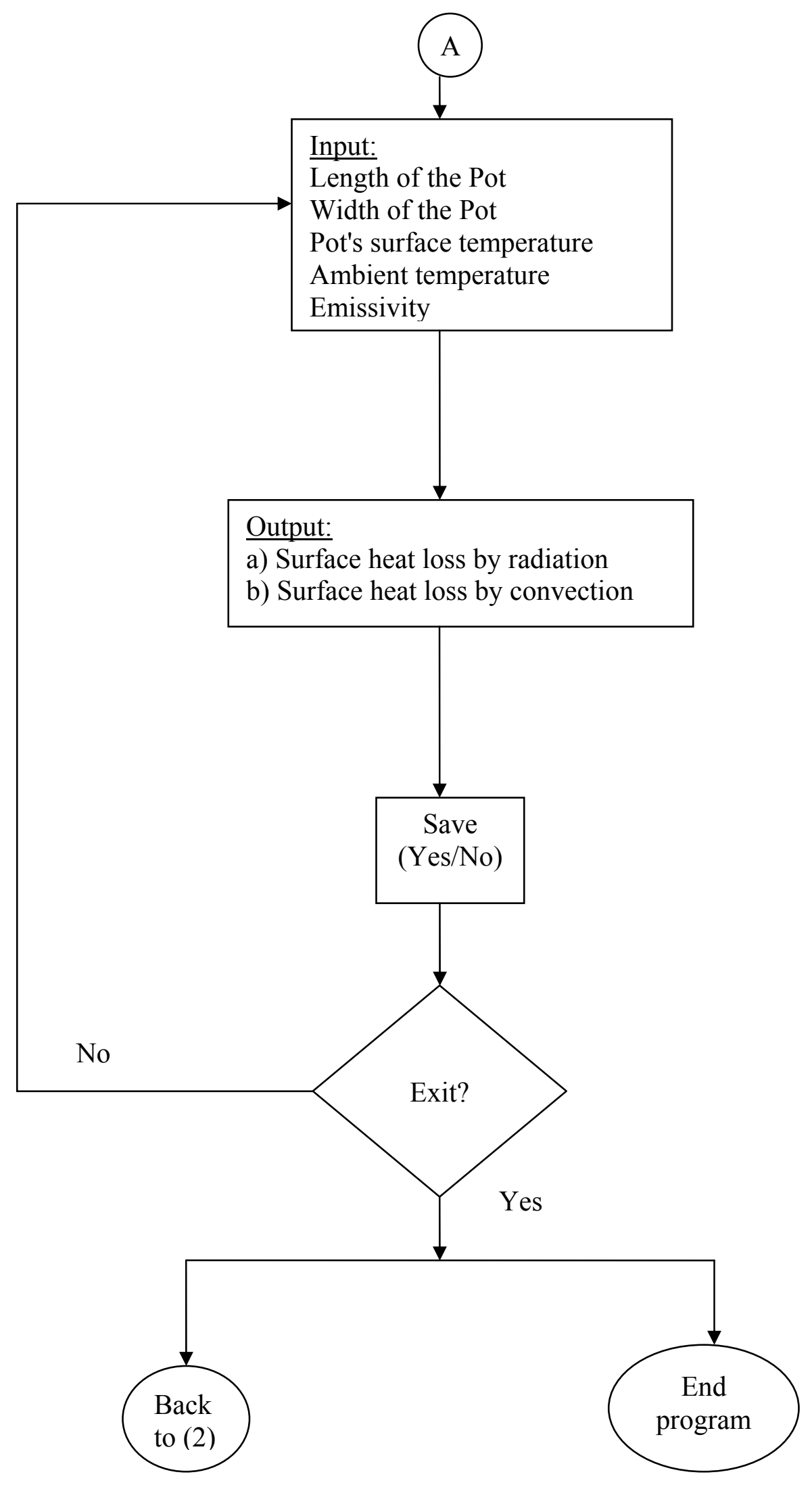

Figure 6: Heat loss from surface 


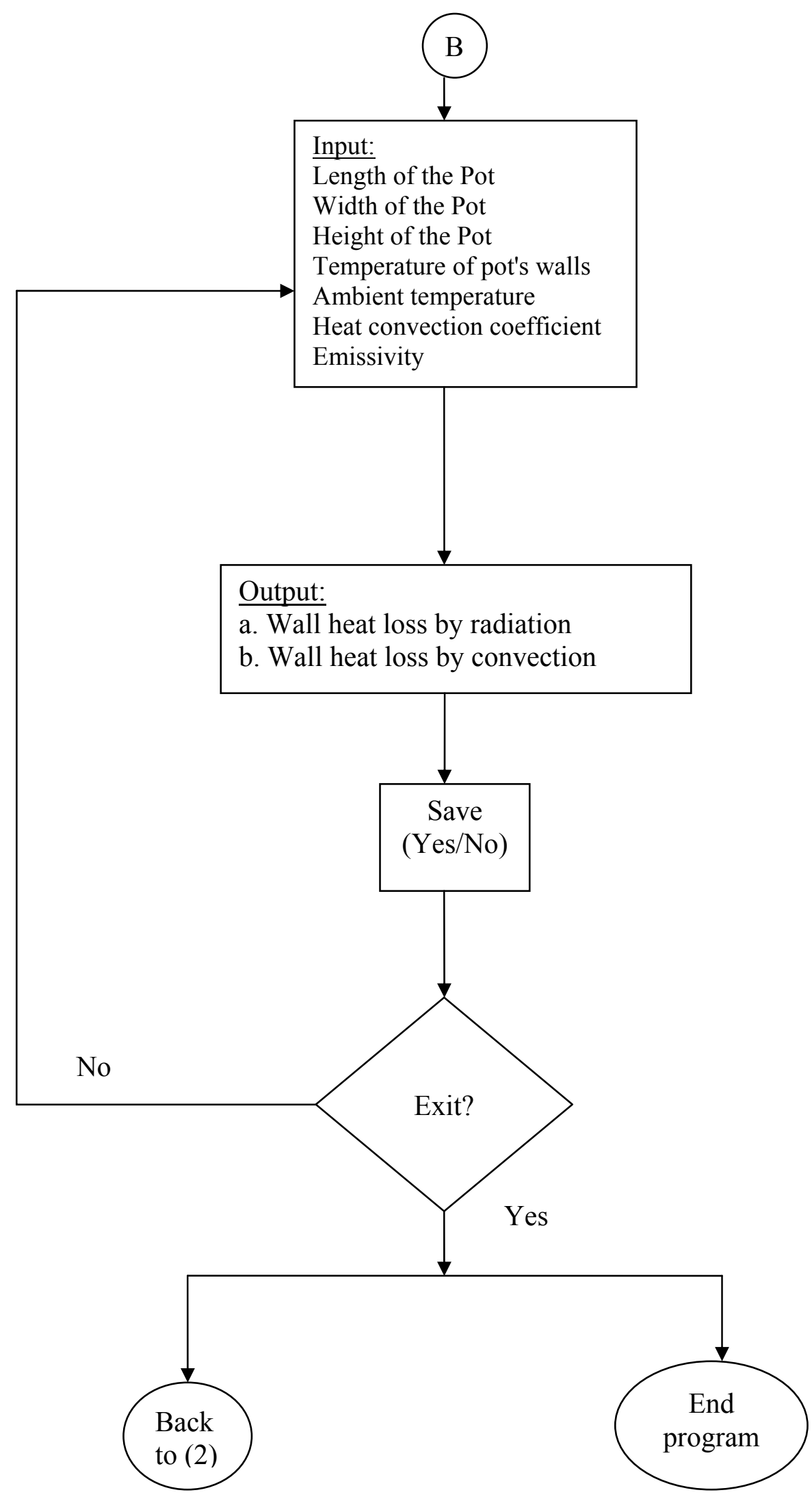

Figure 7: Heat loss through walls 


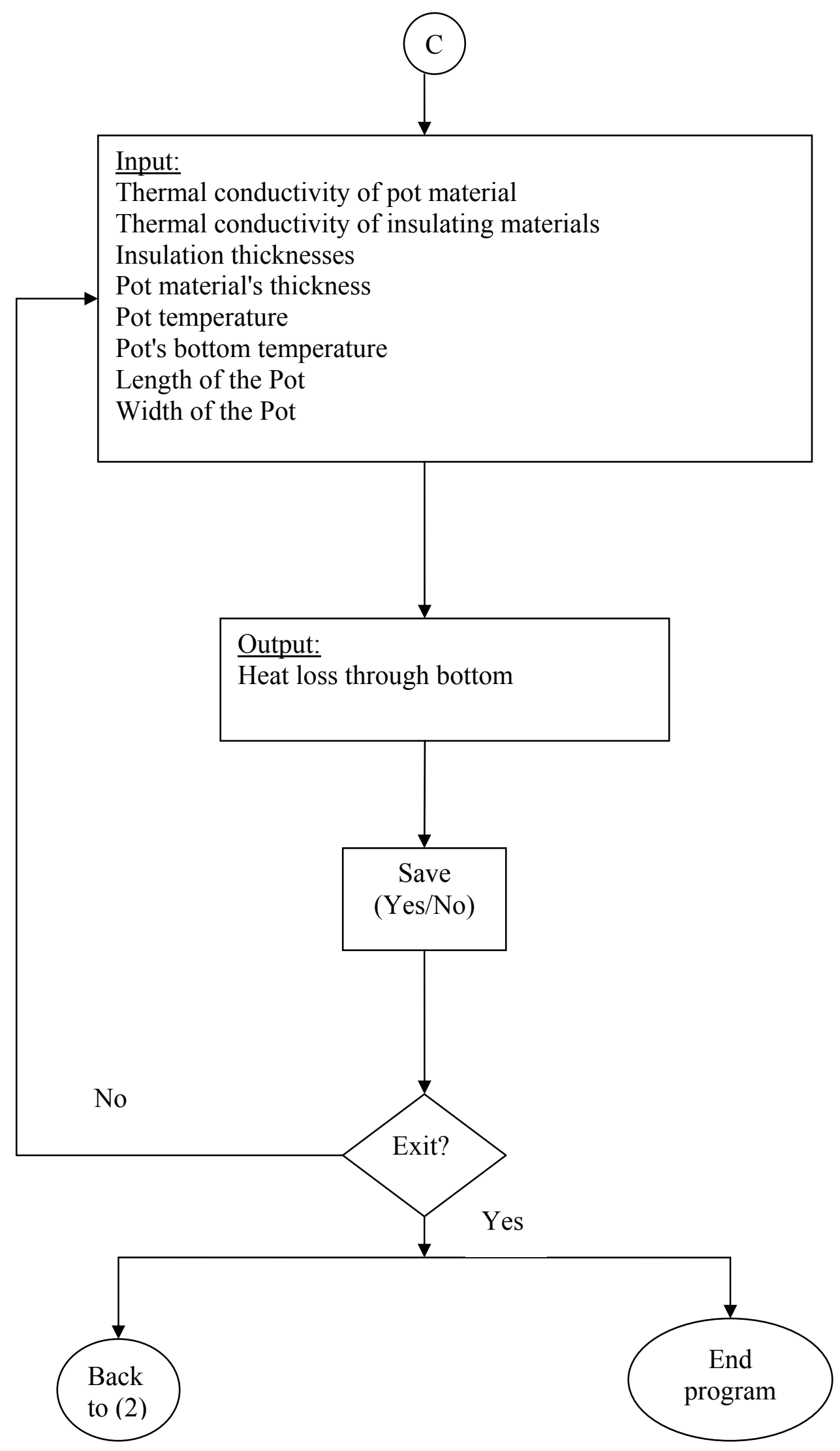

Figure 8: Heat loss through bottom 


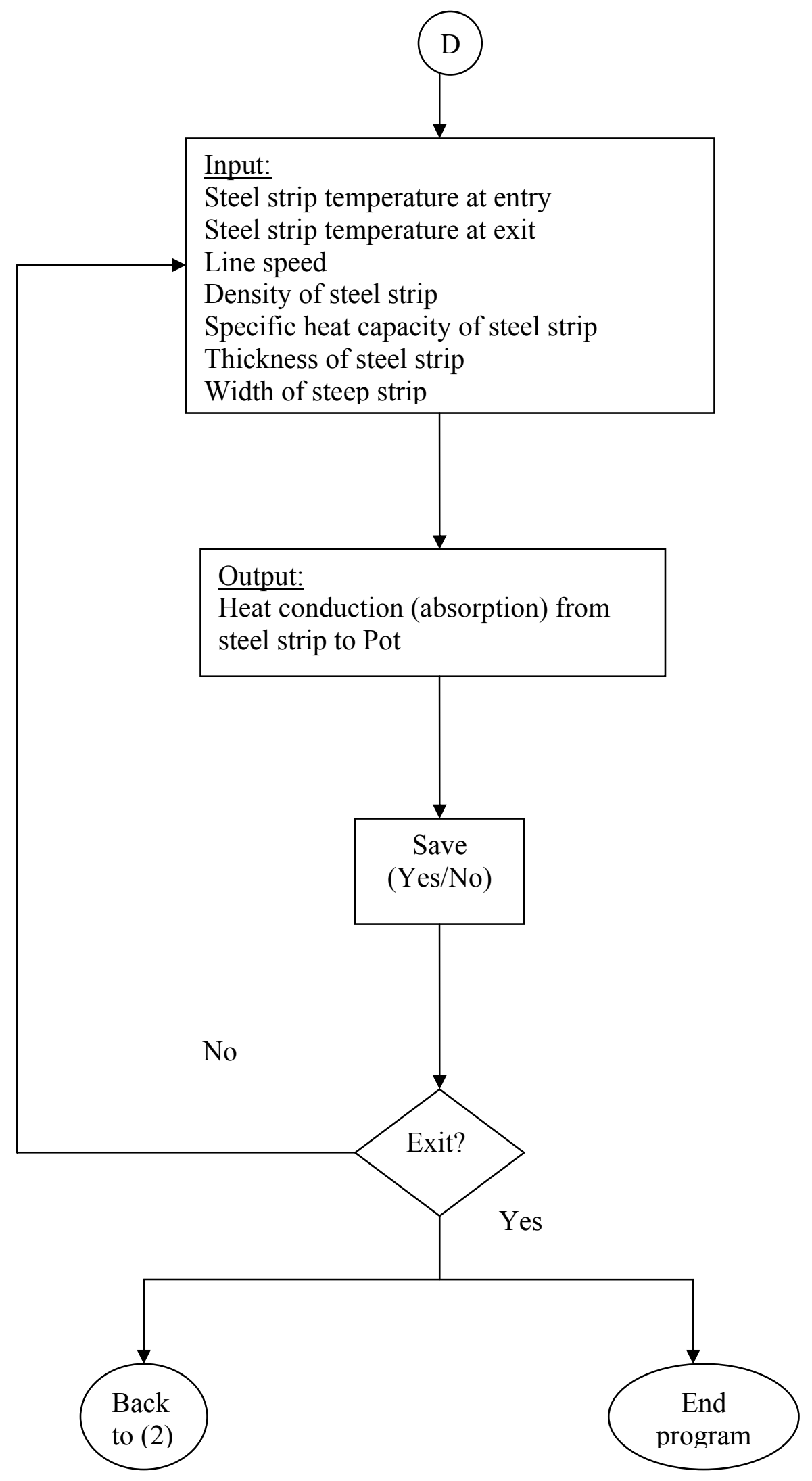

Figure 9: Heat loss to steel strip 


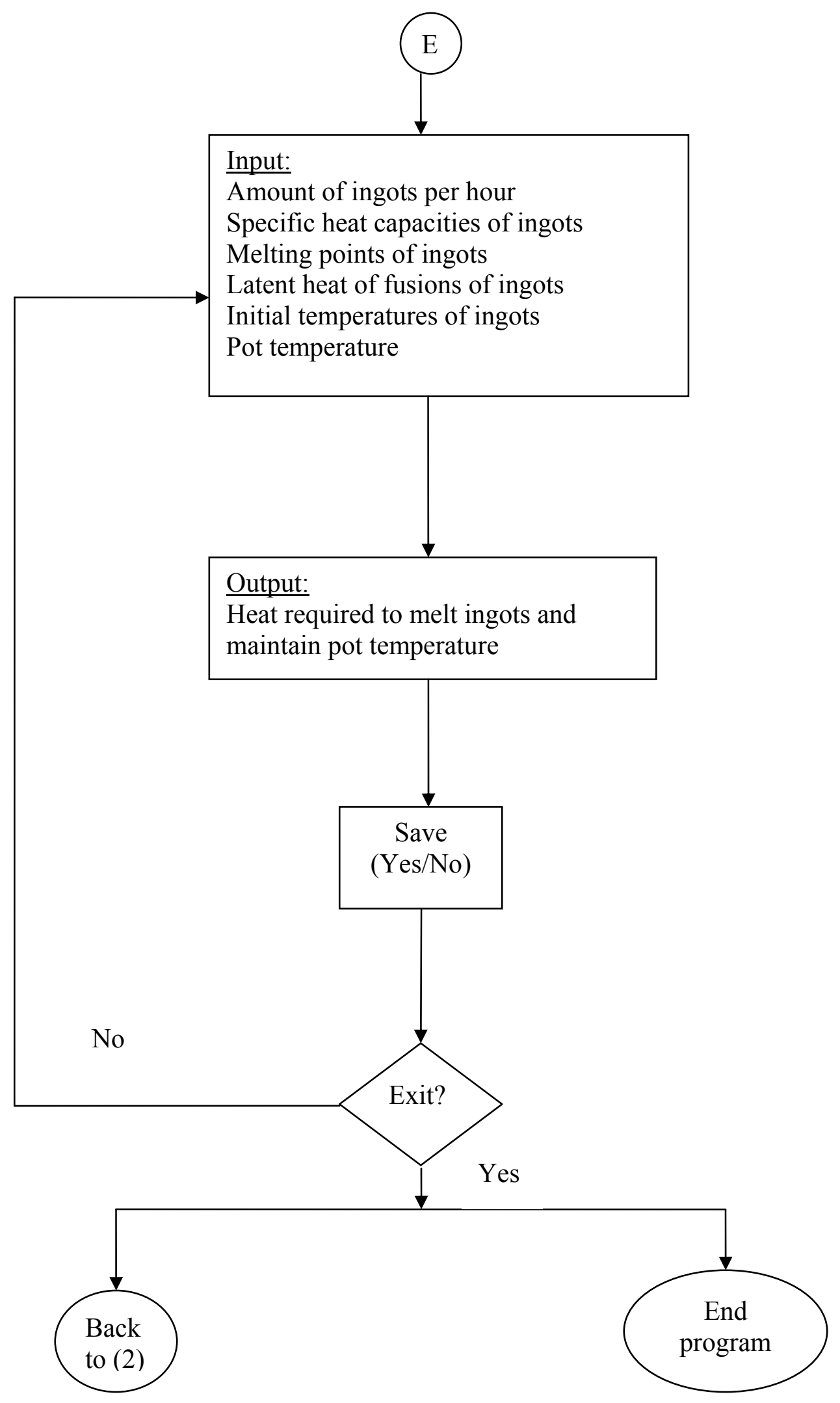

Figure 10: Heat required to melt ingots and maintain pot temperature 


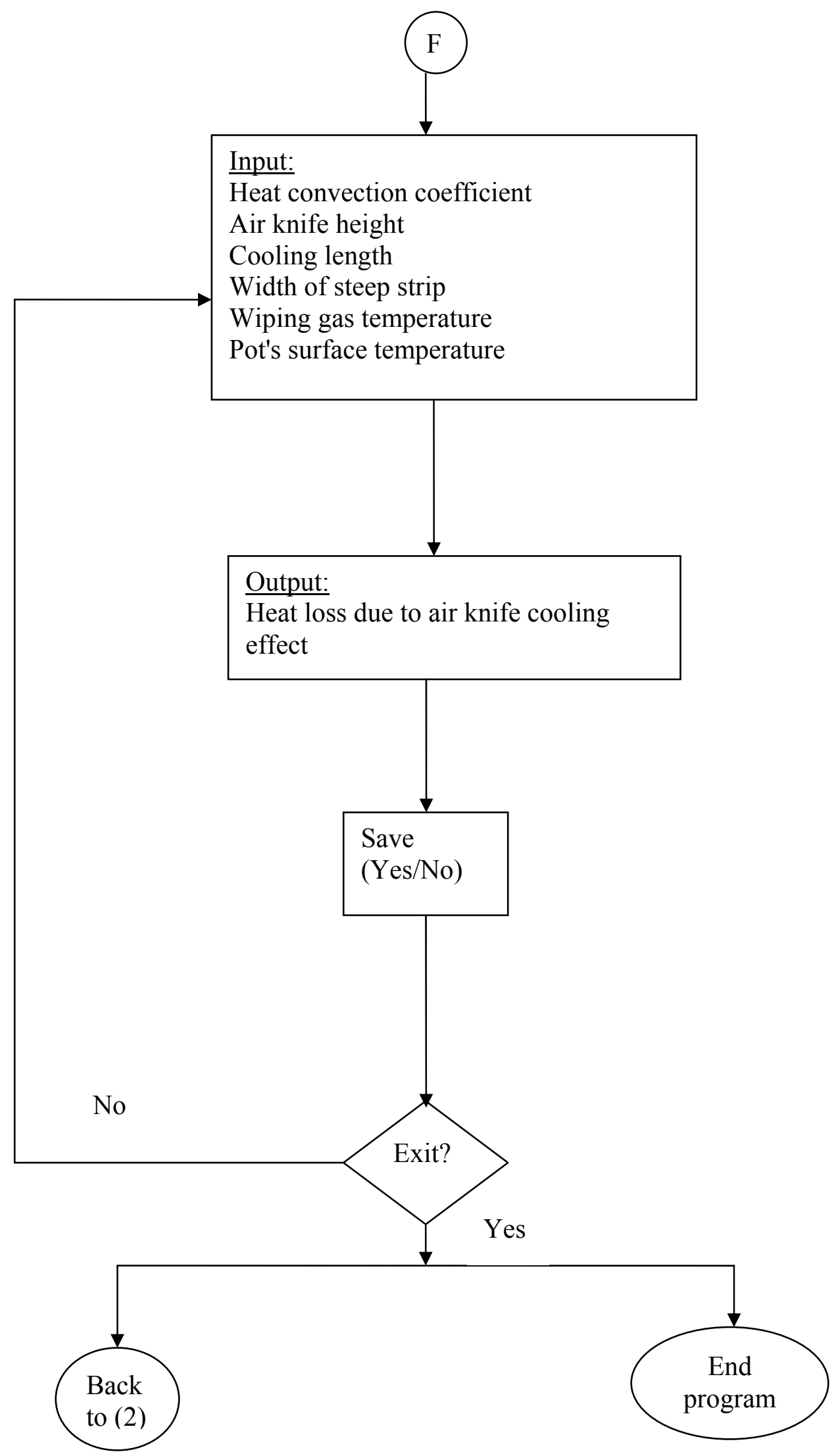

Figure 11: Heat loss due to air knife cooling effect 


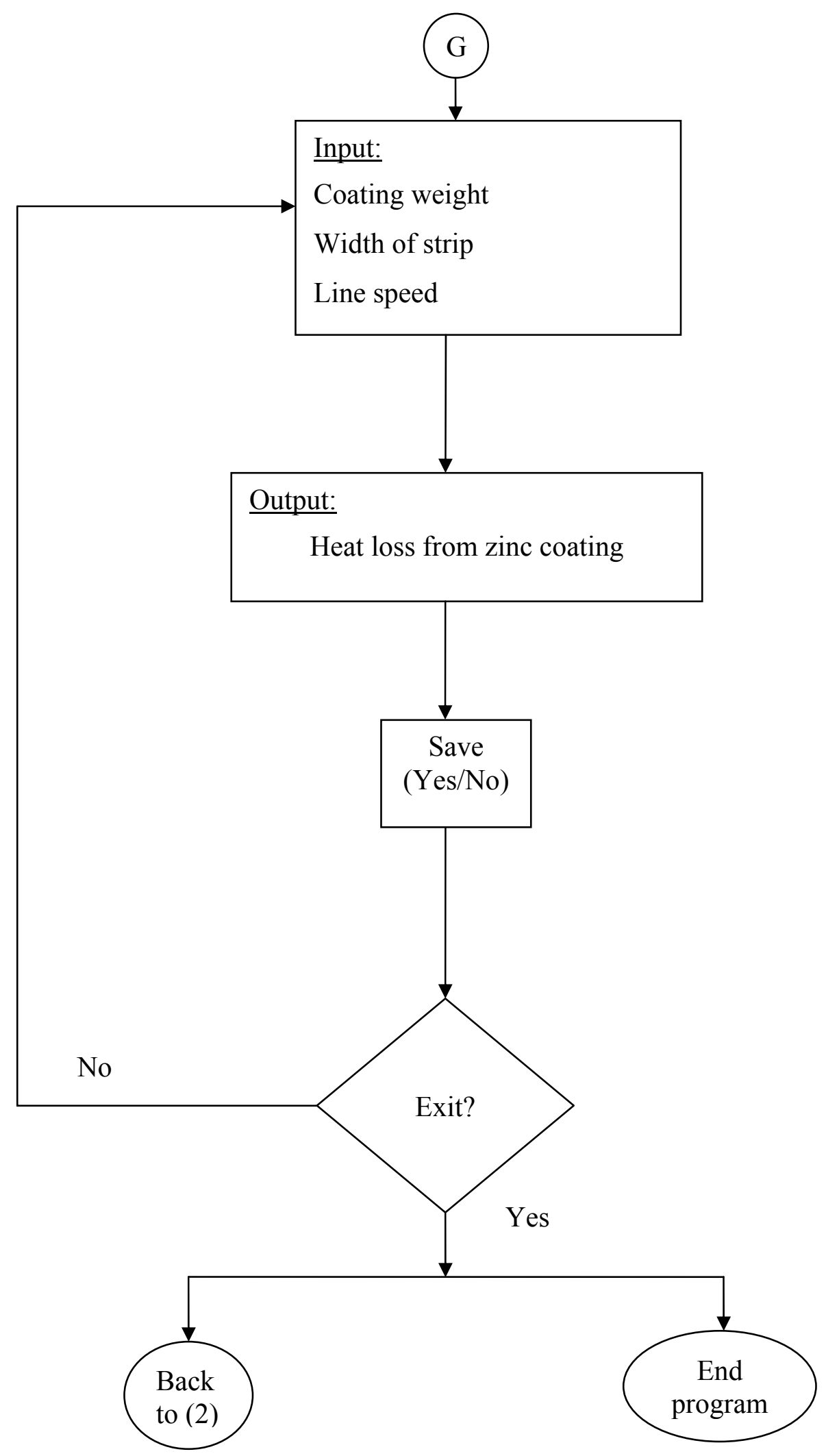

Figure 12: Heat loss from Zn coating 


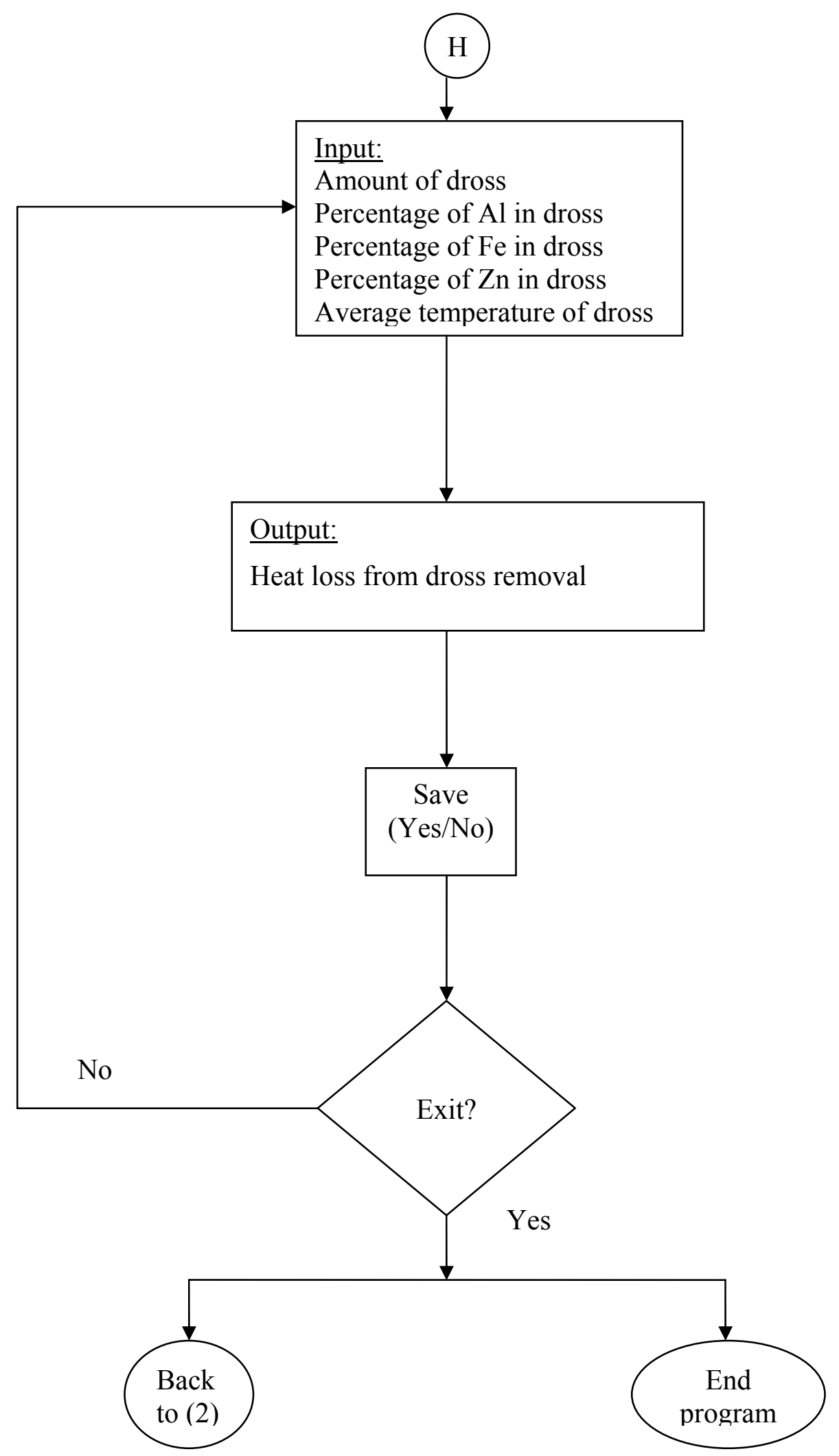

Figure 13: Heat loss from dross removal 


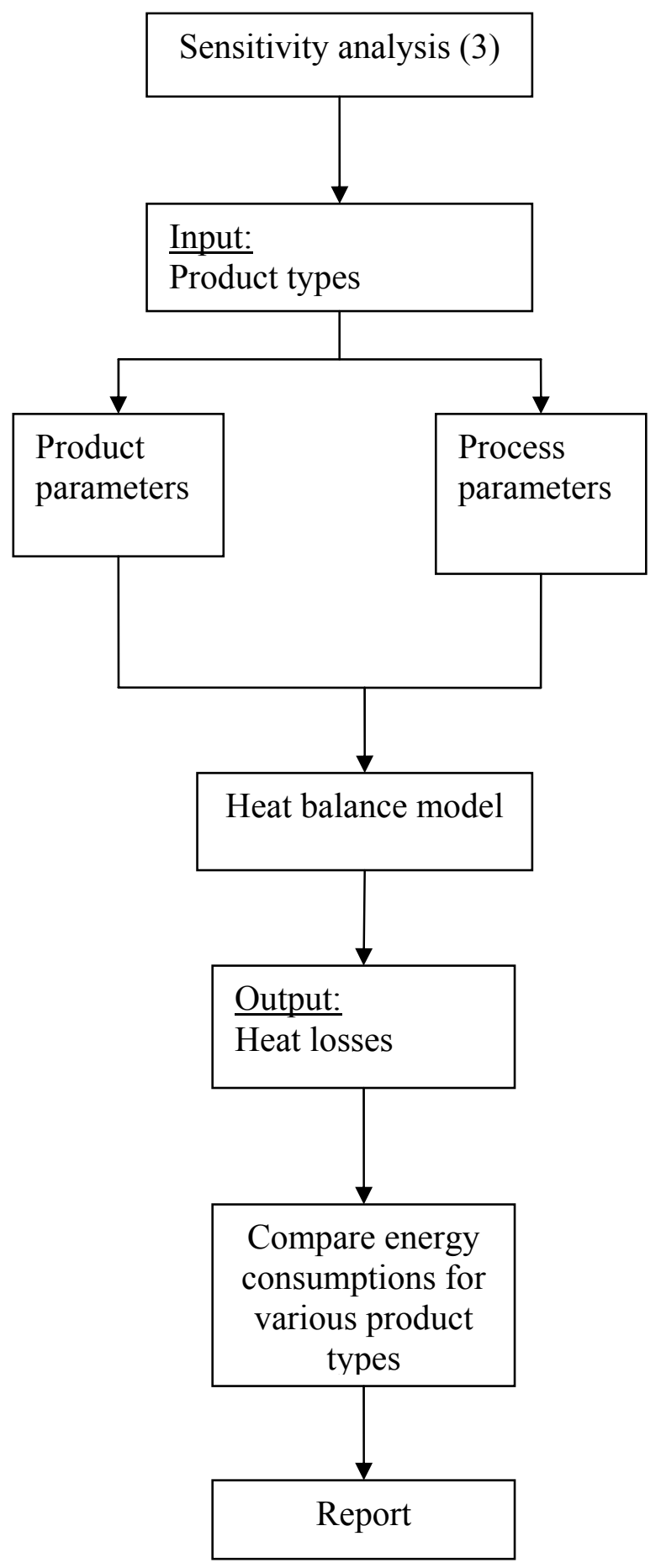

Figure 14: Sensitivity analysis 


\section{$1.8 \quad$ Conclusion}

Galvanizing is an energy intensive industry. The energy consumption varies with different product types associated with different product and process parameters. Heat balance for the pot can be established to determine amount of energy required to produce a certain product type. Sensitivity analysis can be done to study the variations in energy consumption for various product types in the purpose of identifying the potential for energy savings.

GEPDSS was recently developed for modeling a continuous galvanizing line. The research is aimed to quantify the energy consumption in MMBtu/ton of galvanized sheet steel produced and then identify the opportunities for energy conservation. GEPDSS is a static simulation of energy consumption of continuous galvanizing line. It does not consider process and system parameters, variations in energy consumption for different products.

E-GEPDSS (Enhanced Galvanizing Energy Profiler Decision Support System) is the enhancement of the GEPDSS. This E-GEPDSS will complement the existing GEPDSS by including process and product parameters and being able to calculate the amount of energy consumption for different products. E-GEPDSS will concentrate intensively on the most energy consuming processes along the galvanizing. Heat balance determination in the zinc pot will be accomplished. The characteristics of the pot and product details will be used as input to the model. A program will be developed to model the pot heat balance. 


\section{CHAPTER 2: LITERATURE REVIEW}

Hideo Kato presented an outline of continuous galvanizing process and associated electrical equipment [1]. According to the paper, there are three types of galvanizing processes such as Sendzimir process, Gas pickling process, U.S. steel process and Wheeling process. The Sendzimir process developed by Armco Steel in 1936 includes annealing equipment. In gas pickling process, anhydrous hydrogen chloride gas is used, the metal surface is oxidized, and the superficial layer of metal from the strip surface is removed. The U.S. steel process employs electrolytic cleaning before annealing. There is no annealing furnace in the Wheeling process, annealing is carried out separately and annealed coils can be galvanized after alkaline cleaning.

The continuous strip galvanizing line consists of cleaning equipment, a furnace and strip galvanizing pot. Except Wheeling process, annealing furnace is included. The line consists of three sections:

- Entry section: This section consists of coil holder, pinch roll, shear, welder, side trimmer, and bridle. The goal of this section is to feed the strip continuously to the center section. Speed is controlled by speed setter. Tension control is provided to keep the strip move normally. Coil holders are used interchangeably. When one is used for line operation, the other one is free to preparing for welding.

- Center section: In this section, the strip is preheated, annealed and galvanized in the zinc pot. It is then cooled in the cooling tower. Tension control is performed to keep the strip stable. Speed can be varied as well as the control circuit.

- Delivery section: In this section, the strip surface is treated chemically and leveled

and then sheared. Speed of the delivery section depends on the center section. Coil handling is automated. Shear section is normally operated at $15 \%$ speed higher than the delivery section to provide spaces between the sheets.

Several studies have been done on the continuous galvanizing lines as well as the galvanizing pot. F. Ajersch et al. have come up with the numerical simulation of flow in a 
continuous galvanizing pot which considers heat and mass transfer phenomena to better understand the generation and movement of intermetallic dross particles [2]. Dross particles affect the flow pattern, temperature distribution and concentration variations.

Nineteen different operational and configurationally parameters have been used for simulations. Ingots with more $\mathrm{Al}$ in the composition will result in more dross and $\mathrm{Al}$ concentration in the pot. Dross generation can be reduced by slowly adding ingots into the pot. The arrangement of inductor that results in higher mean temperature of the pot will result in lower dross formation. Temperature variations also affect the dross formation and distribution in the pot.

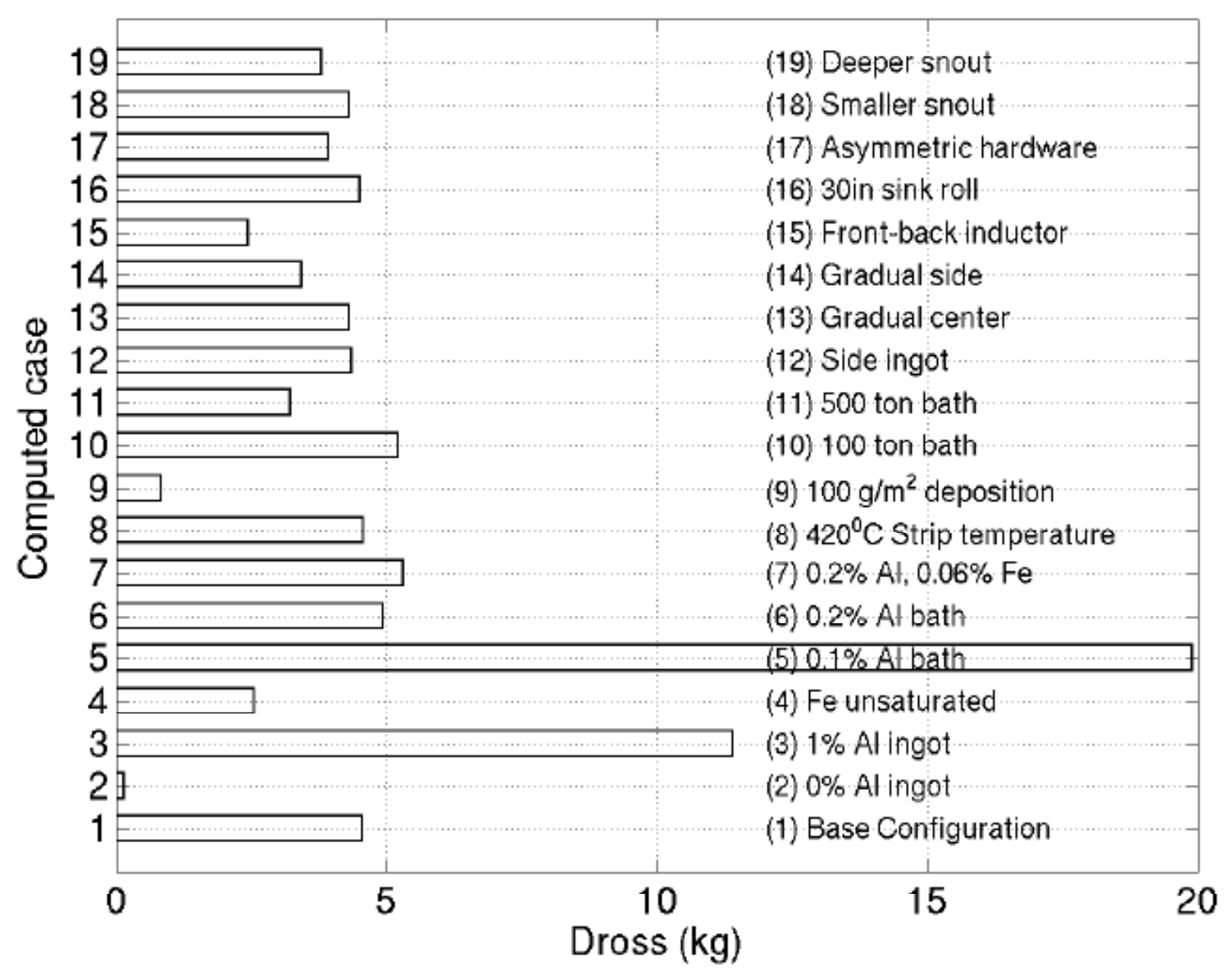

Figure 15: Results from simulation [2]

A zero percent $\mathrm{Al}$ ingot is expected to result in the lowest dross formation $(0.13 \mathrm{~kg})$ whereas the $1 \% \mathrm{Al}$ ingot generates about $11.41 \mathrm{~kg}$. 
A larger pot (500 tons) generates slightly less dross than a smaller pot (100 tons) attributed to generally lower temperature gradients.

The use of ingots with higher Al content results in the formation of additional dross. Gradual ingot immersion results in a very slow increase of dross and a smaller quantity of dross generated.

F. Ajersch et al. have also simulated the velocity and temperature fields in the galvanizing pot using a finite-element analysis [3]. The purpose was to study the thermal effects of adding ingots into the pot to the velocity and temperature fields.

The aluminum contents in the pot vary from 0.10 to $0.13 \mathrm{wt}$ pet for galvannealed and 0.14 to $0.20 \mathrm{wt}$ pet for galvanized products. Coating thickness varies from 10 to $15 \mu \mathrm{m}$, with $<1 \mu \mathrm{m}$ of an inhibition layer. Makeup ingots of $\mathrm{Zn}-\mathrm{Al}$ alloys are added on a regular basis to the pot to maintain the $\mathrm{Zn}$ and $\mathrm{Al}$ contents.

The pot is not isothermal because of the ingots added to make up for the $\mathrm{Zn}$ and $\mathrm{Al}$ deposited on the strip surface. During the ingot melting period, inductor is adjusted to supply heat in order to melt ingots and maintain pot at certain temperature. But this leads to temperature variations in the pot. The temperature at the inductor is higher and lower at the ingot melting region than the pot temperature.

The importance of temperature variations is concerned as compared to the isothermal case. Heat losses through the pot sidewalls, bottom, and pot surface are included in the heat balance, so as to maintain the pot temperature at $460^{\circ} \mathrm{C}$. This information is significantly important in defining the best procedures to minimize dross formation and entrainment.

It has been found that natural convection should be included together with forced convection when studying the movement of liquid zinc in the pot. It has been discovered that inductor operates at maximum power during ingot melting and only $20 \%$ when no ingot additions. Velocity of the strip and movement of the roller will determine the nature of the flow in the region. 
The spatial and temporal distributions of aluminum in the pot are presented in Part II of this study.

In addition to the first part of the article, the second part studies the variation of the solubility of the aluminum and iron as a result of temperature variations [4]. Assuming pot temperature is $460^{\circ} \mathrm{C}$, the surface temperature of the ingot is approximately at $420^{\circ} \mathrm{C}$. Temperature variations in the pot are caused by periodic additions of ingots and the time when there are no ingot additions.

The goal of this second part of the article is to compute spatial and temporal distribution of the aluminum content within the pot during a normal galvanizing operation. To achieve the objective, data on the solubility limits associated with temperature have been integrated into the numerical solution so as to determine the precipitated aluminum $\left(\mathrm{Fe}_{2} \mathrm{Al}_{5}\right)$ as top dross. A software with a $\mathrm{k}-\varepsilon$ turbulence modeling feature developed by the Materials Institute of the National Research Council of Canada (IMI-NRC) has been used for the simulation. Each cycle is 60 minutes, in which 20 minutes of ingot melting period and 40 minutes without ingot. It has been found that the aluminum concentration increases and dross formation decreases when ingots melt, especially in the melting ingot region, due to the decrease of temperature around the ingot surface and aluminum content in the ingots. And there is less aluminum concentration near the strip where the aluminum is consumed. Using the solubility limits of aluminum in the pot as a function of the pot temperature, it was clearly shown that the total and precipitated aluminum contents can be monitored during this sequence.

Sang Joon Lee et al. have conducted a flow field analysis using 1/5 scale transparent water model to study the flow characteristics inside the zinc pot [5]. The dross deposited on the strip surface causes defects and scratches. To resolve the problems caused by dross, flow field inside the zinc pot must be studied and a flow control must be developed.

The purpose of this research is to study the flow field inside the zinc pot and to manage the flow around the stabilizing roll in an effective way. This also helps in control the dross formation in the pot. Strip speed and flow rate of the inductor have been selected to 
be similar to the real operating conditions. The moving speed of the strip and maximum flow rate of induction heater have been set to be $2.0 \mathrm{~m} / \mathrm{s}$ and $6.67 \times 10^{-4} \mathrm{~m}^{3} / \mathrm{s}$ respectively. Scrapers have been attached on the stabilizing rolls to well guide to flow separated from the strips which moves diagonally downward at the speed of $1.5 \mathrm{~m} / \mathrm{s}$.

It has been found that the flow around the stabilizing roll can become stable by attaching scrapers onto the roll (to decrease the flow speed near the stabilizing roll), placing baffles near the strip and operating the induction heater. Knowing these factors will be helpful in reducing top dross attachment in the continuous hot-dip galvanizing process.

Gerald Bloch et al. have introduced some neural intelligent control techniques to improve the quantity and quality of the galvannealed sheet produced on the galvanizing line [6]. The paper has been divided into 4 sections. First section is to present the plant and objectives of the study. Section II aims to monitoring measurements and operating conditions of the annealing process. Section III presents the optimization of the thermal cycle. In section IV, a method to control the annealing furnace is presented.

This study was a work from the French steel company Sollac and the Research Centre for Automatic Control of Nancy (CRAN) to improve the quantity and quality of the galvannealed sheet produced on the galvanizing line on the galvanizing line of Florange, France.

To improve the overall equipment effectiveness (OEE), intelligent control system is adopted to provide reliability while incorporating flexibility and creativity from operators. From total productive maintenance (TPM), sources of production losses come from: stopping, slowing and product defects. One of the means to eliminate or reduce these sources is computer integrated production (CIP).

In this study, neural models have been intensively used for an intelligent control application. Applying intelligent control reduces operator intervention, cost of design, increases increase the fault tolerance and reconfigurability degree of the plant.

A numerical model has been developed to analyze the fluid flow and temperature distributions in a molten zinc pot of No. 2 CGL of POSCO Kwangyang strip mills [7]. 
Numerical simulation can provide comprehensive information on the flow pattern as well as the heat and mass transfer phenomena. The results of this study can be applied to predict the distribution and probability of dross particles that will adhere to the steel strip surface.

One of the findings is that as the steel strip speed varies, overall flow pattern of the pot does not appear to have any significant change. More uniform temperature distribution can be obtained by increasing the line speed. Although steel strip speed has little influence on the flow pattern in the pot but the ingot charging produces non uniform distribution of temperature. A narrower strip width appears to increase the overall density of the floating dross in the pot. Ingot loading position also has a significant impact on the distribution of dross particles. It should be located far away from the point where the steel strip enters the pot and related to the position of inductor.

F.Ajersch et al. have done a research which applies three-dimensional finite-element solution algorithm to predict velocity and temperature fields in a continuous galvanizing pot [8]. The effect of line speed, strip width, strip temperature, and inductor mixing have also been evaluated.

During the ingot melting, the inductor operates at maximum power, resulting in higher thermal effects. It has been found that the steel strip speed and width have significant effect on the fluid flow near the sink and stabilizing rolls but no significant effect near the inductor.

E.A. Elsaadawy has developed a coating weight model for the Continuous Hot-Dip Galvanizing Process [9]. The goal of this model is to predict the coating weight as a function of the process parameters. The model was developed by using a combination of experimental and computation techniques. The maximum deviation between the predicted and measured coating weights was only $8 \%$.

Jet striping or jet wiping is a process in which the air knives control the thickness of the coating by producing air (or gas) jets. Air knives are located just above the pot, using 
either air or $\mathrm{N}_{2}$. A control system which works as a mathematical model to predict coating weight is necessary in this air knife wiping process.

The model is also able to be implemented in an Excel-VBA based spreadsheet application, which can be readily built in the process control system to control the coating thickness. A comprehensive model should also be able to predict the coating properties, which in turn determine the quality of the galvanized product

Frank E. Goodwin et al. have written a paper on Type 316L stainless steel (316L SS) which is commonly used as pot roll material for pot hardware, such as sink and stabilizing rolls, on the continuous galvanizing lines [10]. This type of steel is subject to a corrosive environment in a high temperature zone of molten $\mathrm{Zn}-\mathrm{AL}$ alloy. Pot hardware reacts with molten $\mathrm{Zn}-\mathrm{Al}$ alloy to form intermetallic particles which degrade the performance of the pot. Galvanizing line managers have been seeking a way to improve the performance of pot hardware to improve product quality as well as to reduce costs of repairment and replacement.

316L stainless steel (316L SS) has been widely used in the galvanizing industry for pot equipment because of its high resistance to molten $\mathrm{Zn}-\mathrm{Al}$ alloy at a reasonable cost. $316 \mathrm{~L}$ stainless steel (316L SS) has been tested in a galvanizing line. Some important observations have been made:

- Dross particles attached to samples welded to stationary supporting roll arms were generally smaller in size than samples welded to the sides of the sink roll. This is due to the difference in flow pattern and the iron concentration gradient.

- The turbulent flow created by the rotating sink roll and the Fe dissolved also influence on the dross buildup process.

- An Al-rich layer consisting of the $\mathrm{Fe}_{2} \mathrm{Al}_{5} \mathrm{Zn}_{\mathrm{x}}$ which is called reaction layer is formed when 316L SS is corroded. Dross particles suspended in the pot stick and build on this reaction layer because they have similar crystallographic structure.

A. V. Shitov et al. focus their study on the recycling of the dross formed in hot galvanizing [11]. The use of zinc in continuous galvanizing line is costly, developing an 
effective technology for recycling the dross, recovering zinc from it, and returning that zinc to the production cycle would significantly reduce the cost of production. Recycling dross is difficult. Dross includes roughly equal amounts of metallic and oxidized zinc in combination with intermetallic inclusions of iron and aluminum. About $75 \%$ of the top dross consists of pure part of the melt.

In distillation sublimation, increasing temperature to $1280^{\circ} \mathrm{C}$ helps maximize the amount of zinc recovered. $70-85 \%$ of the zinc is recovered from the dross using this method. Dissolving dross in aluminum melt containing 10-25\% aluminum, the amount of zinc recovered can be up to $70 \%$. The use of ammonium chloride increases the amount of iron removed from the secondary zinc and shortens the recycling operation.

The characteristics of continuous galvanizing pots has been studied intensively by N.Y. Tang [12]. It is widely known that $\mathrm{Al}$ content has a major role in determining the properties of coatings and line production efficiency. The effective $\mathrm{Al}$ and temperature distributions are major concerns for galvanizing line managers.

The $\mathrm{Al}$ content in the pot is small, typically less than $0.2 \mathrm{pct}$ for galvanizing, and 0.005 pct for galvannealing.

Basic equation for iron and aluminum reaction in the pot:

$$
2 \mathrm{Fe}+5 \mathrm{Al}=\mathrm{Fe}_{2} \mathrm{Al}_{5}+\Delta \mathrm{H}
$$

The product of the reaction, $\mathrm{Fe}_{2} \mathrm{Al}_{5}$, acts as an inhibition layer which forms on the surface of the steel strip and prevents $\mathrm{Zn}-\mathrm{Fe}$ reaction at the beginning of ingot immersion. Excess $\mathrm{Fe}_{2} \mathrm{Al}_{5}$ floats on the top surface of the pot as top dross.

Eight parameters which include the strip entry temperature, the pot temperature, the strip thickness, the Al content of the pot, the substrate chemistry, the strip emersion time, and the coating weight, all affect the Al balance in the pot. The strip entry temperature, the pot temperature, and the strip gage which affects the change rate of the strip temperature when it comes into the pot with a different temperature are the most important parameters.

When temperatures increase, the $\mathrm{Al}$ consumption rate increases; and then the formation rate of the compound decreases and the amount of Al taken out from the pot decreases. 
This consequently results in the amount of $\mathrm{Al}$ added to the pot equaling to the amount of $\mathrm{Al}$ being consumed. If the strip entry temperature increases, the pot $\mathrm{Al}$ content decreased slowly because more $\mathrm{Al}$ was consumed as a result of an increased rate of the formation of the inhibition layer in the coating.

It is normal for the inhibition layer to range from 0.1 to $0.2 \mu \mathrm{m}$ thick and contain $\mathrm{Al}$ of approximately 0.2 to $0.4 \mathrm{~g} / \mathrm{m}^{2}$, although automotive industry uses coating of less than 10 $\mu \mathrm{m}$ thick. If coating weight decreases, the total amount of $\mathrm{Al}$ taken out from the pot, in term of weight percentage of the $\mathrm{Zn}$ being consumed, increases and less $\mathrm{Al}$ in the inhibition layer is consumed.

Xingbo Liu et al. have also done a research on the development of a new weld overlay for pot hardware in continuous galvanizing lines [13]. Corrosion and dross buildup on the stabilizer and sink rolls cause shutdown of continuous galvanizing lines. Recently, a new weld overlay (single and multiple layers) of iron-based super alloy on the $316 \mathrm{~L}$ stainless steel substrate has been developed to reduce these effects. Some tests have been done to prove the effectiveness of using this overlay in preventing corrosion and dross build up. The industrial tests show that the new overlay has at least 3 times - better resistance to dross buildup than 316L.

Since 2004, some efforts have been made to improve the corrosion and dross build up resistance. First effort is to study the mechanism of corrosion and dross build up in galvanizing pot. Second effort is to develop new materials and coatings to improve the performance of the hardware as well as extend its service life.

In this research, a new weld overlay of MSA 2020 is used. A number of conclusions have been drawn:

(1) This newly developed overlay has strong resistance to dross buildup; there is almost no buildup on the surface after a 15-day test. In comparison, $316 \mathrm{~L}$ forms a continuous layer of dross after a 6-day test.

(2) The line-scan and X-ray mapping micrographs show that there is a reaction/dissolution layer next to the overlay. Cobalt and iron are dissolved into the pot and aluminum from the pot diffuses into this layer. 
(3) Industrial tests in various galvanizing lines show that this overlay is a candidate for next generation coating on sink and stabilizer rolls in hot-dipping processes.

Takeshi Masui et al. focus their study on Strip Wandering in Processing Plants [14]. Steel strip travels a long distance through the continuous galvanizing line at high speed. Strip shape, thermal effect and other factors are critical to the quality of the galvanized products. This research is concerned with strip wandering which is believed to be due to strip camber and welded joint angle (i.e. non straight form of the strip). Tension leveler has an important role in correcting the shape defects and reducing strip wandering.

An experimental investigation has been carried. Several conclusions have been made:

(1) The main cause of strip wandering is a non-straight form of the strip such as camber and welded joint angle, and the direction of wandering is on the convex side of the strip. Misalignments of the plant have small effects on strip wandering if there is suitable maintenance.

(2) Tension leveling of the strip corrects not only shape defects but also camber and welded joint angle, which effectively depresses strip wandering.

(3) Newly developed centering pinch rolls which can be bent at its center portion by the eccentric ring, generate centering force continuously to reduce strip wandering. They are also effective to prevent irregular weld which may have unexpected gap or unexpected angles.

(4) Newly developed "non-thermal crown hearth roll" has a special barrel to which high thermal conductivity material is bonded. It can reduce thermal crown dramatically to keep an adequate mechanical convex crown that is effective in depressing strip buckling and strip wandering.

(5) Newly developed quenching roll is structured so that the outer sleeve with screwshaped waterways inside is put on the inner sleeve using the shrink fit method. It can reduce thermal crown dramatically to keep adequate mechanical crown that is effective in preventing shape defects and strip wandering. 


\section{Conclusion}

There are more works have been done to study in depths on galvanizing lines, revealing some insights which help galvanizing industry to improve their production, to obtain better products. But there is almost no work that has been done to study about the cost of producing galvanized sheets. With the economic downturn, companies have been under pressure of reducing costs and increasing cash savings. This amount of savings can be reinvested back to renovate the process in order to increase sales and profit. 


\section{CHAPTER 3: RESEARCH APPROACH}

\subsection{Methodology flowchart}

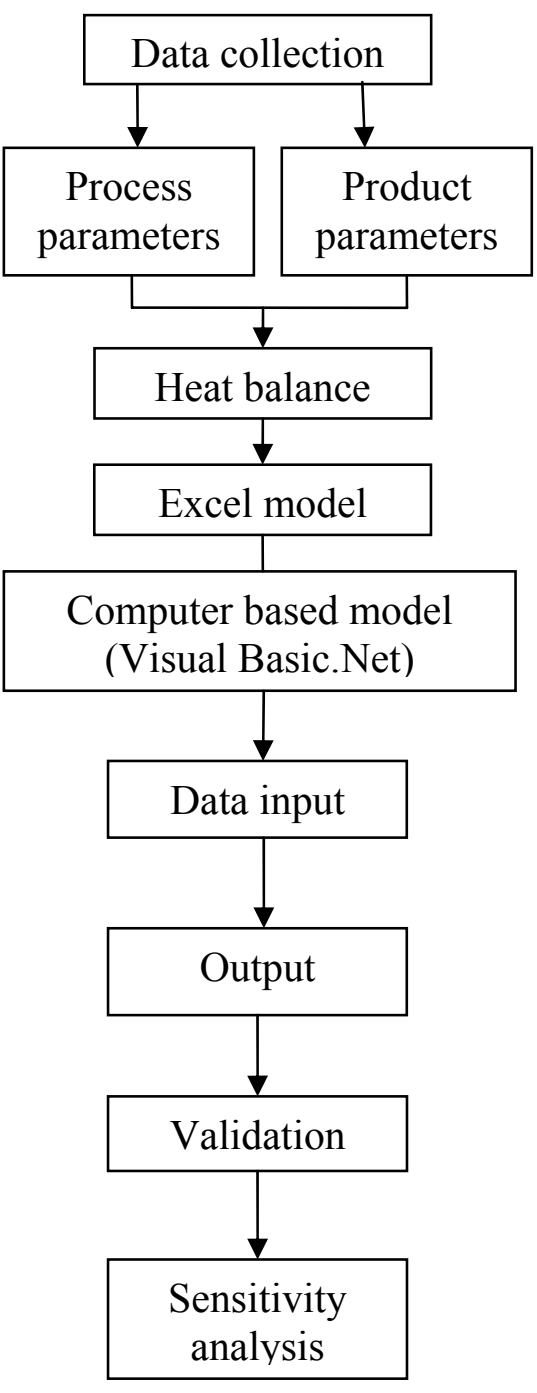

Figure 16: Methodology flowchart

Heat transfer mechanisms of the heat losses for the pot presented in the heat balance are basic heat transfer concepts (i.e. radiation, convection, conduction, and specific heat). Depending on the nature of heat losses, the configurations of the pot and the process, different heat transfer mechanisms can be applied. According to the conservation of energy, energy is only being transferred from one place to another. Therefore, heat input is equal to the summation of all heat losses. Understanding the continuous hot dip 
galvanizing process and hardware will help to determine which mechanism is appropriate for each of the heat losses.

After all heat losses are recognized and heat balance equations are established, an Excel ${ }^{\circledR}$ model for the heat balance will be generated. This Excel ${ }^{\circledR}$ model is based on heat balance equations which accounts for all heat losses and heat input. The Excel ${ }^{\circledR}$ model must produce a relatively accurate estimate of energy consumption with the input data given.

The data collection will be carried out to collect data about the process and products. Process parameters are pot components' dimensions, pot characteristics, pot temperatures. Product parameters are coating weight, physical properties of the strip, and line speed. The data collected during the plant visits will be used to verify the model to the existing energy consumption at the plant for a certain number of product types.

Sensitivity analysis will be performed to facilitate benchmarking studies for individual facilities. It will be carried out on the basis of energy intensity and heat losses for various product types and parameters, as well as pot parameters. Different product types will have different thermal cycles, product and process parameters which will result in relatively different amount of energy consumed in terms of MMBtu/hr (or kW) during production. Details will be discussed to explain and address the energy consumption related to each product. A detailed sensitivity analysis report will be developed to compare and contrast various product types and furnace and pot parameters preserving the confidentiality for the facilities that participate in the study.

From sensitivity analysis, companies will have a general idea of cost versus benefits of producing various products in terms of energy usage. This helps in the decision making process of plant managers in the effort of obtaining an optimal production plan to maximize profit. 


\subsection{E - GEPDSS model}

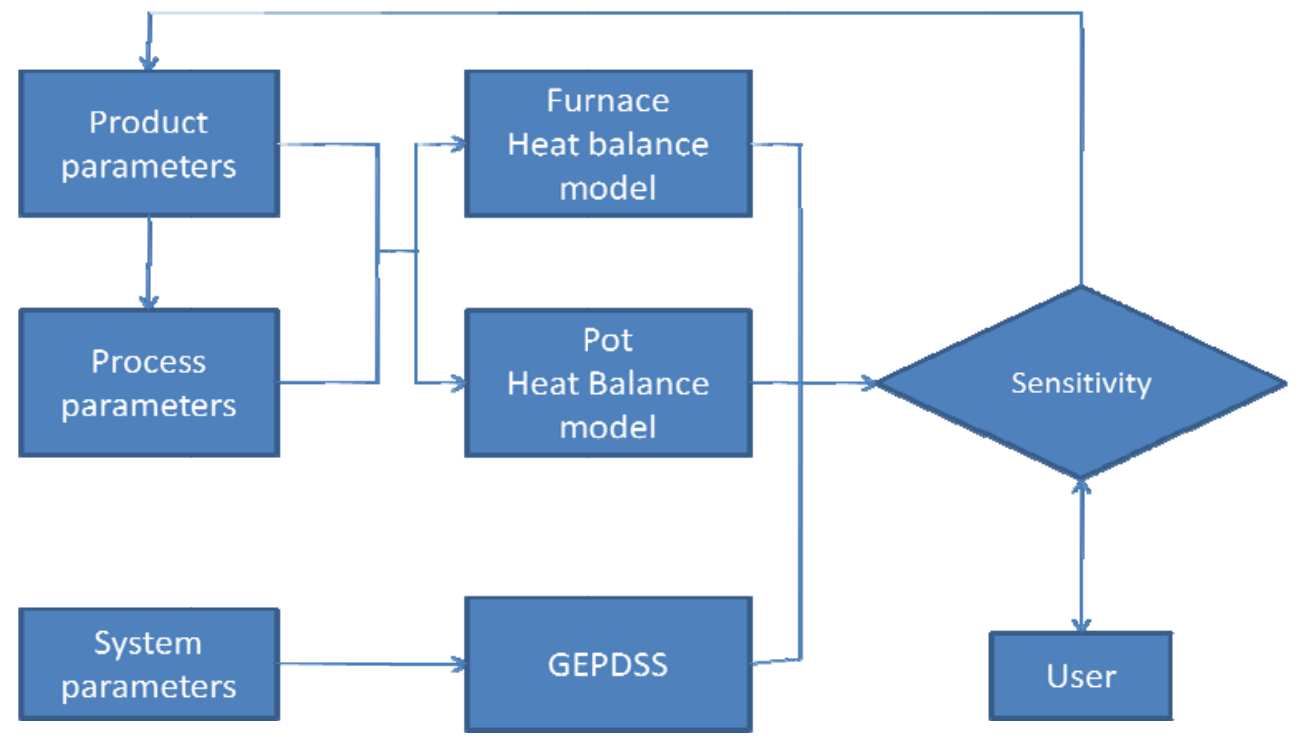

Figure 17: E - GEPDD model flowchart

GEPDSS requires system parameters as input such as energy cost, electric usage, natural gas usage and production parameters. GEPDSS works on the entire galvanizing line for the total natural gas and electricity consumption. E-GEPDSS, which is the enhancement of GEPDSS, on the other hand is concerned with heat losses on specific process (in this research it is pot). E-GEPDSS requires input from product parameters such as coating weight, line speed, steel strip thickness and width. It also imports process parameters such as temperature of the pot, temperature of the strip at entry of the pot, etc.

From the output (i.e. computed energy consumption) obtained in the model, sensitivity analysis can be done by adjusting certain parameters (e.g. line speed, strip width, etc) to analyze the impact of these parameters to energy usage.

\subsection{Heat transfer mechanism}

\section{a) Conduction}

Heat conduction is the transfer of thermal energy between neighboring molecules in a substance due to a temperature gradient. It always takes place from a region of higher temperature to a region of lower temperature, and acts to equalize temperature differences. 
When dealing with a multilayer partition, the following formula is usually used [20]:

$$
Q=\frac{A \Delta T}{\frac{t_{1}}{k_{1}}+\frac{t_{2}}{k_{2}}+\frac{t_{3}}{k_{3}}+\ldots}
$$

$\mathrm{t}_{1}, \mathrm{t}_{2}, \mathrm{t}_{3} \ldots .:$ Thicknesses of insulations $1,2,3 \ldots$

$\mathrm{k}_{1}, \mathrm{k}_{2}, \mathrm{k}_{3} \ldots .$. Thermal conductivities of insulations $1,2,3 \ldots$

A: Cross sectional surface area

$\Delta T:$ Temperature difference between the ends.

\section{b) Convection:}

\section{Natural convection}

When heat is transferred by the circulation of fluids due to buoyancy from the density changes induced by heating itself [20].

Forced convection

Transfer of heat is due to movement in the fluid which results from many other forces [20].

$Q=h A \Delta T$

$\mathrm{H}$ : Heat convection coefficient

A: Cross sectional surface area

$\Delta T:$ Temperature difference between atmosphere and surface temperature

\section{c) Radiation}

Heat radiation is the process by which the surface of an object radiates its thermal energy in the form of electromagnetic waves [20].

$Q=\varepsilon B A\left(T_{s}^{4}-T_{a}^{4}\right)$

$\varepsilon$ : Emissivity

B: Stephen Boltzmann constant

$\mathrm{T}_{\mathrm{s}}$ : Surface temperature

$\mathrm{T}_{\mathrm{a}}$ : Ambient temperature 


\section{d) Heat content}

Enthalpy is used to describe the heat content of a system. Temperature $77^{0} \mathrm{~F}\left(298^{0} \mathrm{~K}\right)$ is known as the base temperature, and $\mathrm{H}_{\mathrm{T}}-\mathrm{H}_{298}$ represents the heat content above base temperature. $\mathrm{H}_{\mathrm{T}}-\mathrm{H}_{298}$ is commonly called the "sensible heat" which includes the heat in all transformations.

$H_{T}-H_{298}=a T+b T^{2}+c T^{-1}+d$

$\mathrm{H}_{\mathrm{T}}, \mathrm{H}_{298}$ are in $\mathrm{kcal} / \mathrm{kg} . \mathrm{mol}$

$\mathrm{T}$ is in ${ }^{0} \mathrm{~K}$

$\mathrm{a}, \mathrm{b}, \mathrm{c}, \mathrm{d}$ : coefficients for substance (given in the Appendix)

\subsection{Mass balance}

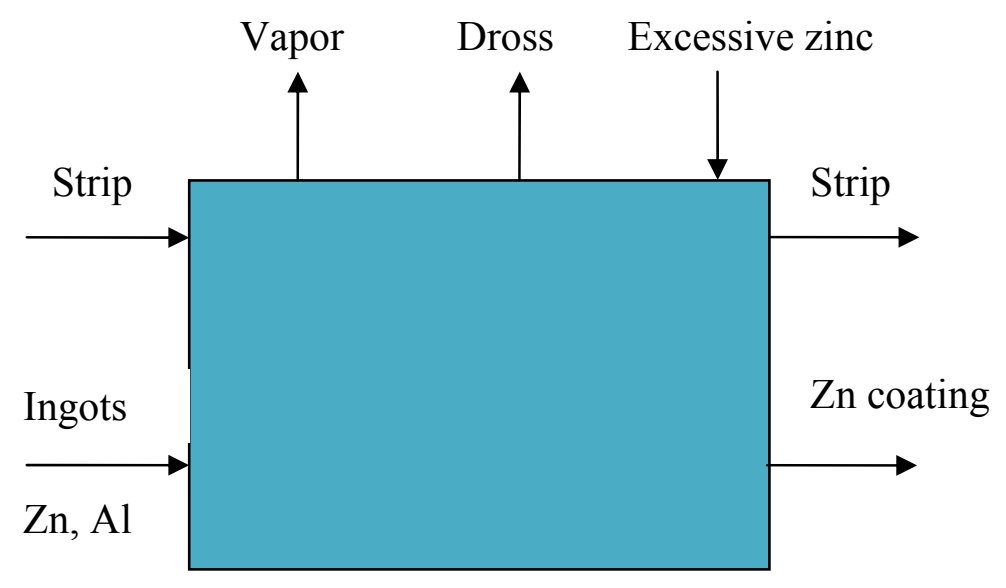

Figure 18: Mass balance

Pot healt balance is actually based on the mass balance of the system. Mass balance refers to the conservation of mass. The material going in must be equal to the material leaving out of the system. The mass balance analysis starts with determining the material going in and out of the pot. Strip is coming into the pot with a certain speed and ingots are added to the pot every hour. Strip is also coming out after being submerged in the pot together with the liquid zinc on the strip surface. Dross is skimmed out of the pot surface after a certain time. Excessive zinc which is wiped out of the strip surface flows back to the pot. There is also a small amount of metal being vaporized from the pot surface. 
After the mass balance is recognized, the heat balance components can be identified based on the material or mass balance component associated with the heat loss.

\subsection{Heat balance}

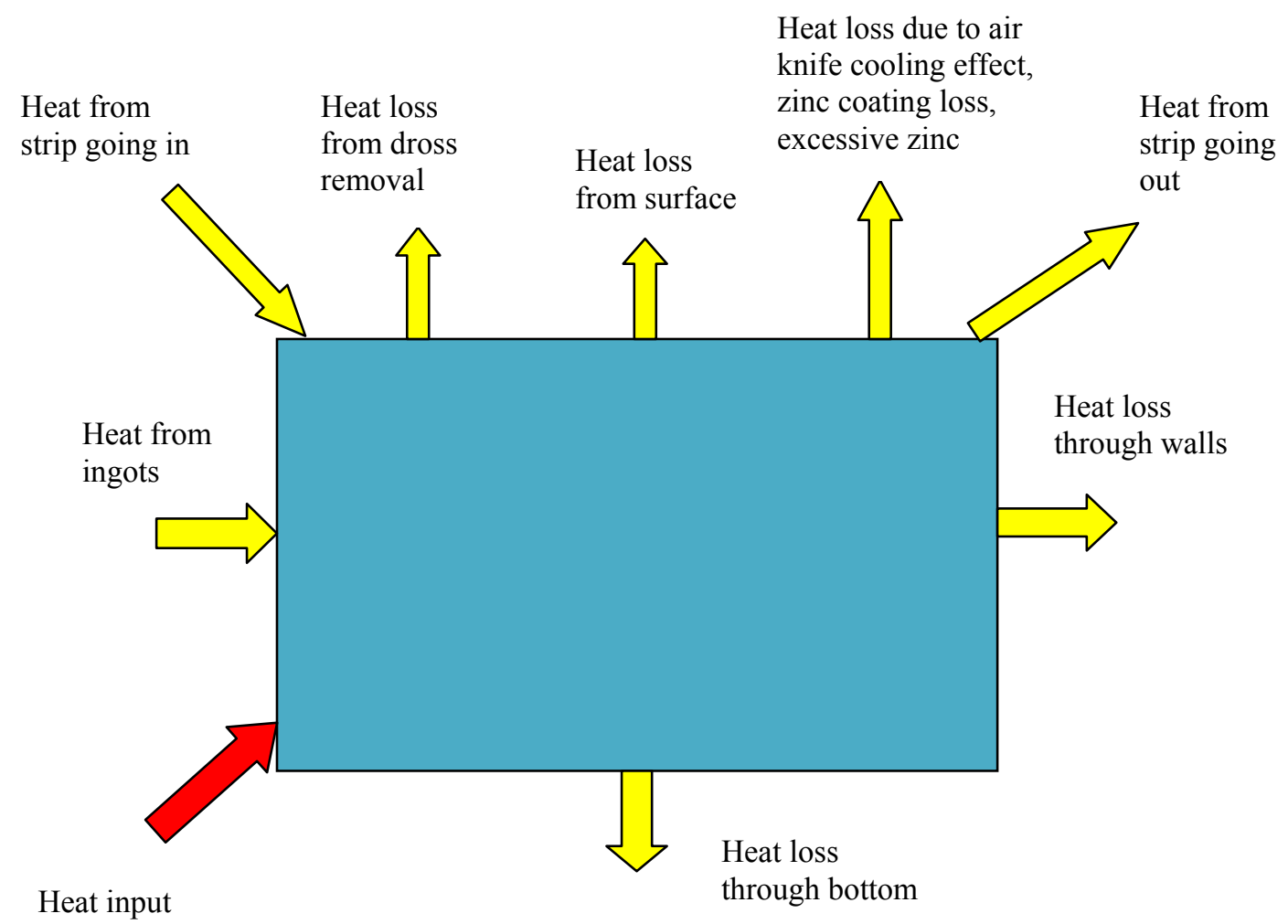

Figure 19: Heat balance diagram

Heat balance consists of heat input to the pot and heat losses from it to the surroundings and the steel strip, when the temperature of the strip is lower than the temperature of the pot. Heat losses can come from the surface, walls and bottom, by natural heat convection and radiation. Even when the production is stopped, pot temperature must still be maintained at certain temperature (e.g. $870^{\circ} \mathrm{F}$ ) to keep the zinc in liquid form. When such case happens, heat is dissipated from surface, walls and bottom, even when the steel strip is not coming into the pot.

A relative large amount of energy is also needed to melt ingots which are added to the pot (or pre-melt pot) every hour to compensate for the zinc being consumed during production. 
When air knives are blowing to wipe off the excessive zinc on the surface of the steel strip, the air flow is traveling along the steel strip back to the surface of the pot, cooling down the pot surface. This leads to an increase of power required to keep the pot temperature at desired temperature.

\subsubsection{Heat required to melt ingots and maintain the pot temperature}

For galvanizing lines that are not using a pre-melt pot to melt ingots, the electric grid can operate at $100 \%$ power when ingots are being added directly to the main pot. For melting metal, energy required consists of two components. One is to heat up the ingots to melting temperature and the other is to change the state of ingots from solid to liquid. This amount of energy can be calculated using latent heat of fusion for specific metals or alloys. Ingots are usually added every hour. Ingots usually are pure zinc and zincaluminum alloy. Only a small amount of aluminum is consumed during the production. Amount of ingots needed depend on strip characteristics such as strip width, coating thickness as well as process parameters such as line speed.

\section{Calculation:}

$$
\mathrm{Q}=\text { Sensible heat } \mathrm{x} \text { Amount of substance (in } \mathrm{kg} . \mathrm{mol} / \mathrm{hr} \text { ) }
$$

Amount of pure $\mathrm{Zn}$ ingot $=\frac{\mathrm{lbs}}{\mathrm{hr}} \mathrm{Zn} \times \frac{1 \mathrm{lb} \mathrm{mol}}{65.38 \mathrm{lbs} \mathrm{Zn}} \times \frac{1 \mathrm{~kg}}{2.2 \mathrm{lbs}}=\frac{\mathrm{kg} \cdot \mathrm{mol}}{\mathrm{hr}} \mathrm{Zn}$

Amount of Al in Al-Zn ingot $=\frac{l b s}{h r} A l \times \frac{1 \mathrm{lb} \mathrm{mol}}{26.98 \mathrm{lbs} A l} \times \frac{1 \mathrm{~kg}}{2.2 \mathrm{lbs}}=\frac{\mathrm{kg} \cdot \mathrm{mol}}{\mathrm{hr}} \mathrm{Al}$

Amount of $\mathrm{Zn}$ in Al-Zn ingot $=\frac{\mathrm{lbs}}{\mathrm{hr}} \mathrm{Zn} \times \frac{1 \mathrm{lb} \mathrm{mol}}{65.38 \mathrm{lbs} \mathrm{Zn}} \times \frac{1 \mathrm{~kg}}{2.2 \mathrm{lbs}}=\frac{\mathrm{kg} \cdot \mathrm{mol}}{\mathrm{hr}} \mathrm{Zn}$

Sensible heat of substance at $\mathrm{T}^{0} \mathrm{~K}: \mathrm{H}_{\mathrm{T}}-\mathrm{H}_{298}=\frac{\mathrm{aT}+\mathrm{bT}^{2}+\mathrm{cT}^{-1}+\mathrm{d}}{1000}$

$\mathrm{H}_{\mathrm{T}}-\mathrm{H}_{298}$ is in Mcal $/ \mathrm{kg} . \mathrm{mol}$

a, b, c, d: coefficients for substance (given in the Appendix)

\subsubsection{Heat loss from the surface}

\section{a) Convection heat loss}

As the surface of the pot is exposed to the atmosphere, heat convection occurs from the surface whenever there is a temperature difference between the surface and the 
atmosphere. Dross build-up due to dissolved iron forms intermetallic alloys. Dross can be found floating on the top or on the bottom of the pot. The top dross reduces the amount of heat convection from the surface. When the top dross is removed, heat which has been trapped under this top dross layer is released. Convection heat loss from the surface is difficult to be calculated because of the complexity of temperature distribution on the surface. Heat convection occurs mostly where hot zinc is exposed directly to the atmosphere and the least where it is covered by the top dross. It is difficult to calculate correctly the actual amount of heat convection from the surface.

\section{Calculation:}

$$
Q=h A\left(T_{s}-T_{a}\right)
$$

Q: Heat loss due to convection from the molten zinc surface $(\mathrm{Btu} / \mathrm{hr})$

h: Convection coefficient (Btu/hr. $\left.\mathrm{ft}^{2}{ }^{0} \mathrm{~F}\right)$

A: Top surface area $\left(\mathrm{ft}^{2}\right)$

$\mathrm{T}_{\mathrm{s}}$ : Pot surface temperature $\left({ }^{0} \mathrm{~F}\right)$

$\mathrm{T}_{\mathrm{a}}$ : Ambient temperature $\left({ }^{0} \mathrm{~F}\right)$

Convection coefficient $(\mathrm{h})$ can be calculated by the procedure below. This procedure is adapted from the Heat Transfer book by Adrian Bejan [18]. The convection coefficient is computed followed by the procedure in background of the program, and the SI units that can be seen in this procedure do not affect the units of the input and output of the program.

Step 1: Calculate film temperature

$$
T_{f}=\frac{\left(\frac{T_{s}-32}{1.8}+\frac{T_{a}-32}{1.8}\right)}{2}
$$

$\mathrm{T}_{\mathrm{f}}$ : Film (average) temperature $\left({ }^{0} \mathrm{C}\right)$ between pot surface temperature and ambient temperature

$\mathrm{T}_{\mathrm{s}}$ : Pot surface temperature $\left({ }^{0} \mathrm{~F}\right)$

$\mathrm{T}_{\mathrm{a}}$ : Ambient temperature $\left({ }^{0} \mathrm{~F}\right)$

Step 2: Calculate Rayleigh number

$$
R a=\frac{g \beta}{v \alpha}\left(T_{s}-T_{a}\right)(L \times 100)^{3}
$$

L: Characteristic length (m) 
$g$ : Acceleration due to gravity $\left(\mathrm{m} / \mathrm{s}^{2}\right)$

$\beta$ : Thermal expansion coefficient $\left(\mathrm{K}^{-1}\right)$

$v$ : Kinematic viscosity $\left(\mathrm{m}^{2} / \mathrm{s}\right)$

$\alpha:$ Thermal diffusivity $\left(\mathrm{m}^{2} / \mathrm{s}\right)$

where

$$
\frac{g \beta}{v \alpha}=\frac{\left(T_{f}-200\right)(4.96-9.53)}{300-200}+9.53 \text { (refer to Figure } 7 \text { in Appendix) }
$$

and

$$
L=\frac{\text { length } \times \text { width }}{2(\text { length }+ \text { width })}
$$

Length: Length of the pot (m)

Width: Width of the pot (m)

Step 3: Calculate Nusselt number

$$
N u=0.15 \times\left(R a L^{\frac{1}{3}}\right)
$$

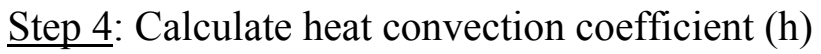

where

$$
h=\frac{N u \times k}{L}
$$

$$
k=\frac{\left(T_{f}-200\right)(0.045-0.039)}{(300-200)}+0.039
$$

\section{(refer to Figure 7 in Appendix)}

\section{b) Radiation heat loss}

Heat radiation occurs from the surface of the pot. Radiation depends on the temperature difference between the pot surface and the atmosphere. It also depends upon the emissivity of the surface (e.g. zinc surface, dross).

Calculation:

$$
Q=\varepsilon B A\left(T_{s}^{4}-T_{a}^{4}\right)
$$

Q: Heat loss due to radiation from the molten zinc surface $(\mathrm{Btu} / \mathrm{hr})$

$\mathcal{E}$ : Emissivity

B: Stephen Boltzmann constant $\left(\mathrm{Btu} / \mathrm{hr} . \mathrm{ft}^{2} .{ }^{0} \mathrm{R}^{4}\right)$

A: Top surface area $\left(\mathrm{ft}^{2}\right)$ 
$\mathrm{T}_{\mathrm{s}}$ : Pot surface temperature $\left({ }^{0} \mathrm{R}\right)$

$\mathrm{T}_{\mathrm{a}}$ : Ambient temperature $\left({ }^{0} \mathrm{R}\right)$

\subsubsection{Heat loss through the walls of the pot}

Heat is going through the wall via heat conduction mechanism, starting from the inner side of the wall of the pot to the outside wall which is exposed to the atmosphere. The temperature of the pot may range from 800 to 860 degree F. Outside wall's temperature depends on the material properties and configurations of insulation layers installed for the pot. This amount of heat is then convected and radiated to the atmosphere. This means heat conduction between the wall ends should equal the sum of heat convection and radiation. This heat is dissipated to the surrounding and is constant if pot temperature does not change. Radiation heat loss depends on the material painted on the outside wall. The painting material has its own emissivity value and this will be used to calculate the radiation heat loss. Convection heat loss depends on the temperature at the surface of the outside wall.

\section{Calculation:}

a) Heat convection:

$$
Q=h A\left(T_{w}-T_{a}\right)
$$

Q: Heat loss due to convection from the walls $(\mathrm{Btu} / \mathrm{hr})$

h: Heat convection coefficient $\left(\mathrm{Btu} / \mathrm{hr} . \mathrm{ft}^{2} .{ }^{0} \mathrm{~F}\right)$

A: Total wall area $\left(\mathrm{ft}^{2}\right)$

$\mathrm{T}_{\mathrm{w}}$ : Outside wall temperature $\left({ }^{0} \mathrm{~F}\right)$

$\mathrm{T}_{\mathrm{a}}$ : Ambient temperature $\left({ }^{0} \mathrm{~F}\right)$

b) Heat radiation:

$$
Q=\varepsilon B A\left(T_{w}^{4}-T_{a}^{4}\right)
$$

Q: Heat loss due to radiation from the walls $(\mathrm{Btu} / \mathrm{hr})$

$\mathcal{E}:$ Emissivity

B: Stephen Boltzmann constant 
A: Total wall area $\left(\mathrm{ft}^{2}\right)$

$\mathrm{T}_{\mathrm{w}}$ : Outside wall temperature $\left({ }^{0} \mathrm{R}\right)$

$\mathrm{T}_{\mathrm{a}}:$ Ambient temperature $\left({ }^{0} \mathrm{R}\right)$

\subsubsection{Heat loss through the bottom by heat conduction}

The mechanism for heat loss through the bottom of the pot is similar to heat loss through the walls. Only heat conduction is considered in this case because the bottom of the pot is installed under the ground. Heat loss is due to the difference in temperatures of the pot and atmosphere. Amount of heat loss depends on the material properties and configuration of the pot and insulation layers at the bottom of the pot.

\section{$\underline{\text { Calculation: }}$}

$$
Q=\frac{A\left(T_{p}-T_{b}\right)}{\left(\frac{t_{p}}{k_{p}}+\frac{t_{1}}{k_{1}}+\frac{t_{2}}{k_{2}}\right)}
$$

Q: Heat loss through the bottom by heat conduction (Btu/hr)

$\mathrm{t}_{\mathrm{p}}$ : Thickness of pot material (ft)

$\mathrm{t}_{1}$ : Thickness of insulating material $1(\mathrm{ft})$

$\mathrm{t}_{2}$ : Thickness of insulating material $1(\mathrm{ft})$

$\mathrm{k}_{\mathrm{p}}$ : Thermal conductivity of pot material (Btu/hr.ft. $\left.{ }^{0} \mathrm{~F}\right)$

$\mathrm{k}_{1}$ : Thermal conductivity of insulating material 1 (Btu/hr.ft. $\left.{ }^{0} \mathrm{~F}\right)$

$\mathrm{k}_{2}$ : Thermal conductivity of insulating material $2\left(\mathrm{Btu} / \mathrm{hr} . \mathrm{ft} .{ }^{0} \mathrm{~F}\right)$

A: Area of the bottom of the pot $\left(\mathrm{ft}^{2}\right)$

$\mathrm{T}_{\mathrm{p}}$ : Temperature of the inner side of the pot $\left({ }^{0} \mathrm{~F}\right)$

$\mathrm{T}_{\mathrm{b}}$ : Temperature of the surface of insulating material $\left({ }^{0} \mathrm{~F}\right)$ 


\subsubsection{Heat gain/loss from steel strip going through the pot}

Steel strip going to the pot can be at a temperature higher or lower than the pot temperature. When it enters with a higher temperature, it will supply heat to the pot. When the steel strip enters the pot at lower temperature than that of the pot, it will absorb heat and gain temperature. It can reach up to the pot temperature after it exits the surface.

\section{Calculation:}

$$
\mathrm{Q}=\text { Sensible heat } \mathrm{x} \text { Amount of Fe (in } \mathrm{kg} \cdot \mathrm{mol} / \mathrm{hr} \text { ) }
$$

Q: Heat gain/loss from the steel strip (Btu/hr)

$\mathrm{m}$ : Amount of Fe (lbs/hr)

Where $\mathrm{m}=\mathrm{d} * \mathrm{~L} * \mathrm{t} * \mathrm{~W} * 60$

$\mathrm{d}$ : Density of steel $\left(\mathrm{lb} / \mathrm{ft}^{3}\right)$

L: Line speed ( $\mathrm{ft} / \mathrm{min})$

$\mathrm{t}$ : thickness of the steel strip (ft)

w: width of the steel strip (ft)

$$
\text { Amount of } \mathrm{Fe}=\frac{\mathrm{lbs}}{\mathrm{hr}} \mathrm{Fe} \times \frac{1 \mathrm{lb} \mathrm{mol}}{55.85 \mathrm{lbs} F e} \times \frac{1 \mathrm{~kg}}{2.2 \mathrm{lbs}}=\frac{\mathrm{kg} \cdot \mathrm{mol}}{\mathrm{hr}} \mathrm{Fe}
$$

Sensible heat of substance at $\mathrm{T}^{0} \mathrm{~K}: \mathrm{H}_{\mathrm{T}}-\mathrm{H}_{298}=\frac{\mathrm{aT}+\mathrm{bT}^{2}+\mathrm{cT}^{-1}+\mathrm{d}}{1000}$

$\mathrm{H}_{\mathrm{T}}-\mathrm{H}_{298}$ is in Mcal/kg.mol

a, b, c, d: coefficients for Fe $(\alpha)$ (given in the Appendix)

$\mathrm{T}_{\text {exit }}$ : Temperature of the strip at the entry $\left({ }^{0} \mathrm{~K}\right)$

$\mathrm{T}_{\text {entry }}:$ Temperature of the strip at the exit $\left({ }^{0} \mathrm{~K}\right)$

\subsubsection{Heat loss due to air knife cooling effect}

Heat loss is also due to air knife cooling when air knives are wiping off the excess zinc to achieve the desired strip coating thickness. The air or nitrogen from the air knives blows at the steel strip surface and separates into two directions. One is along the direction of the steel strip and the other is towards the pot. Since the air knives are blowing at two sides of the steel strip, heat loss is by forced convection. This forced convection takes place at the point where the air/gas is blowing and down to the pot where the steel strip is 
coming out. The process diagram of the air knife cooling effect is given in Figure 8 in Appendix.

Calculation:

$$
\mathrm{Q}=2 \mathrm{hw}\left(\mathrm{T}_{\mathrm{s}}-\mathrm{T}_{\mathrm{wp}}\right)\left(\mathrm{h}_{\mathrm{a}}+\mathrm{l}_{\mathrm{c}}\right)
$$

Q: Heat loss due to air knife cooling effect (Btu/hr)

h: Heat convection coefficient $\left(\mathrm{Btu} / \mathrm{hr} . \mathrm{ft}^{2} .{ }^{0} \mathrm{~F}\right)$

w: Strip width (ft)

$\mathrm{T}_{\mathrm{s}}$ : Pot surface temperature $\left({ }^{0} \mathrm{~F}\right)$

$\mathrm{T}_{\mathrm{wp}}$ : Wiping gas temperature $\left({ }^{0} \mathrm{~F}\right)$

$\mathrm{h}_{\mathrm{a}}$ : Air knife height $(\mathrm{ft})$

$1_{\mathrm{c}}$ : Cooling length $(\mathrm{ft})$

\subsubsection{Heat loss from zinc coating}

This heat loss is related to the zinc being coated on the steel strip surface. Zinc goes from liquid to solid as it coats on the steel. The solidification process is opposite to the melting process in which metal is heated to melting temperature and then changes phase from solid to liquid.

\section{Calculation:}

$$
\mathrm{Q}=\text { Sensible heat } \mathrm{x} \text { Amount of } \mathrm{Zn} \text { coating (in } \mathrm{kg} \cdot \mathrm{mol} / \mathrm{hr} \text { ) }
$$

Q: Total amount of heat loss (Btu/hr)

$\mathrm{T}_{\mathrm{Z}}:$ Zinc temperature $\left({ }^{0} \mathrm{~F}\right)$

Sensible heat of $\mathrm{Zn}$ at $\mathrm{T}^{0} \mathrm{~K}: \mathrm{H}_{\mathrm{T}}-\mathrm{H}_{298}=\frac{\mathrm{aT}+\mathrm{bT}^{2}+\mathrm{cT}^{-1}+\mathrm{d}}{1000}$

$\mathrm{H}_{\mathrm{T}}-\mathrm{H}_{298}$ is in Mcal/kg.mol

$\mathrm{a}, \mathrm{b}, \mathrm{c}, \mathrm{d}$ : coefficients for $\mathrm{Zn}$ (given in the Appendix)

Where $\mathrm{m}=C W \times L \times W \times 0.0625 \times 60$

$\mathrm{m}$ : amount of $\mathrm{Zn}$ coating $(\mathrm{lbs} / \mathrm{hr})$ 
$\mathrm{CW}$ : Coating weight $\left(\mathrm{oz} / \mathrm{ft}^{2}\right)$

L: Line speed (ft/min)

W: Width of strip (ft)

Amount of $\mathrm{Zn}=\frac{\mathrm{lbs}}{\mathrm{hr}} \mathrm{Zn} \times \frac{1 \mathrm{lb} \mathrm{mol}}{65.38 \mathrm{lbs} \mathrm{Zn}} \times \frac{1 \mathrm{~kg}}{2.2 \mathrm{lbs}}=\frac{\mathrm{kg} \cdot \mathrm{mol}}{\mathrm{hr}} \mathrm{Zn}$

\subsubsection{Heat loss from dross removal}

Dross is formed due to the dissolution of iron which in turn forms a solid intermetallic compound in the pot. This dross is built up during the production and floats on the surface of the pot. Dross is removed every hour to maintain the stability of the pot and quality of zinc coating on the strip surface. Dross contains heat. Therefore the removal of dross implies a heat loss to the system.

\section{Calculation:}

$$
\mathrm{Q}=\mathrm{Q}_{1}+\mathrm{Q}_{2}+\mathrm{Q}_{3}
$$

$\mathrm{Q}_{1}$ : Potential heat of Fe

$\mathrm{Q}_{2}$ : Potential heat of Al

$\mathrm{Q}_{3}$ : Potential heat of $\mathrm{Zn}$

$\mathrm{Q}_{1}=$ Sensible heat of Fe $\mathrm{x}$ Amount of Fe (in kg.mol/hr)

$\mathrm{Q}_{2}=$ Sensible heat of $\mathrm{Al} x$ Amount of $\mathrm{Al}$ (in kg.mol/hr)

$\mathrm{Q}_{3}=$ Sensible heat of $\mathrm{Zn} \times$ Amount of $\mathrm{Zn}$ (in $\mathrm{kg} \cdot \mathrm{mol} / \mathrm{hr}$ )

Sensible heat of Fe at $\mathrm{T}^{0} \mathrm{~K}: \mathrm{H}_{\mathrm{T}}-\mathrm{H}_{298}=\frac{\mathrm{aT}+\mathrm{bT}^{2}+\mathrm{cT}^{-1}+\mathrm{d}}{1000}$

a, b, c, d: coefficients for $F e(\alpha)$ (given in the Appendix)

Sensible heat of $\mathrm{Al}$ at $\mathrm{T}^{0} \mathrm{~K}: \mathrm{H}_{\mathrm{T}}-\mathrm{H}_{298}=\frac{\mathrm{aT}+\mathrm{bT}^{2}+\mathrm{cT}^{-1}+\mathrm{d}}{1000}$

$\mathrm{a}, \mathrm{b}, \mathrm{c}, \mathrm{d}$ : coefficients for $\mathrm{Al}$ (given in the Appendix)

Sensible heat of Zn at $\mathrm{T}^{0} \mathrm{~K}: \mathrm{H}_{\mathrm{T}}-\mathrm{H}_{298}=\frac{\mathrm{aT}+\mathrm{bT}^{2}+\mathrm{cT}^{-1}+\mathrm{d}}{1000}$ 
a, b, c, d: coefficients for Zn (given in the Appendix)

$\mathrm{H}_{\mathrm{T}}-\mathrm{H}_{298}$ is in $\mathrm{Mcal} / \mathrm{kg} . \mathrm{mol}$

\subsubsection{Heat loss due to excessive zinc}

Excessive zinc is wiped out of the strip surface to obtain the required coating weight on the strip. This amount of excessive zinc is cooled down by natural convection as well as forced convection due to the air knife wiping effect. This cooled excessive zinc flows back to the pot with the temperature lower than the pot temperature. This will have an effect of cooling down the pot which results in a heat loss to the system.

\section{Calculation:}

$$
\mathrm{Q}=\text { Sensible heat } \mathrm{x} \text { Amount of excessive zinc (in } \mathrm{kg} . \mathrm{mol} / \mathrm{hr} \text { ) }
$$

Q: Total amount of heat loss (Btu/hr)

$\mathrm{T}_{\mathrm{z}}$ : Zinc temperature $\left({ }^{0} \mathrm{~F}\right)$

Sensible heat of $\mathrm{Zn}$ at $\mathrm{T}^{0} \mathrm{~K}: \mathrm{H}_{\mathrm{T}}-\mathrm{H}_{298}=\frac{\mathrm{aT}+\mathrm{bT}^{2}+\mathrm{cT}^{-1}+\mathrm{d}}{1000}$

$\mathrm{H}_{\mathrm{T}}-\mathrm{H}_{298}$ is in Mcal $/ \mathrm{kg} . \mathrm{mol}$

$\mathrm{a}, \mathrm{b}, \mathrm{c}, \mathrm{d}$ : coefficients for $\mathrm{Zn}$ (given in the Appendix)

Amount of excessive $\mathrm{Zn}=\frac{\mathrm{lbs}}{\mathrm{hr}} \mathrm{Zn} \times \frac{1 \mathrm{lb} \mathrm{mol}}{65.38 \mathrm{lbs} \mathrm{Zn}} \times \frac{1 \mathrm{~kg}}{2.2 \mathrm{lbs}}=\frac{\mathrm{kg} \cdot \mathrm{mol}}{\mathrm{hr}} \mathrm{Zn}$ 


\subsubsection{Heat input to the pot}

Heat input to the pot is necessary to compensate for heat losses and to maintain the pot temperature. Energy can be supplied by one of the following methods.

- Electricity

- Natural gas

The heating capacity of the main pot and pre-melt pot are important to determine the energy consumption. Example values are as below.

Heating capacity:

- Main pot: $400 \mathrm{~kW}=1.37 \mathrm{MMBtu} / \mathrm{hr}$

- Pre melt pot: $800 \mathrm{~kW} \quad=2.73 \mathrm{MMBtu} / \mathrm{hr}$

\subsubsection{Variations on energy consumption during production and downtime}

During production time, all heat losses are considered in the heat balance. During downtime, steel strip is not going through the pot, ingots are not needed, and neither are air knives. But it is still necessary to maintain the pot at certain temperature which is close to operating temperature. Therefore other heat losses such as heat loss through walls, heat loss from the surface and bottom are still considered in the heat balance. And heat required to melt ingots, heat loss to the steel strip and heat loss due to cooling effect from air knives are removed from the heat balance.

\subsubsection{Load Factor}

Load factors for the main pot and pre-melt pot are determined from this study. It can be calculated using the formulae below.

$$
\text { Load factor }=\frac{\text { Heat input }}{\text { Full operating capacity }}
$$




\subsection{Program}

The program consists of 11 worksheets: Pot model, Mass balance, Heat balance, Summary, Dross, Ingot, Strip, Zinc coating, Excessive zinc, Background, and Reference.

\subsubsection{Pot model}

This worksheet consists of 3 parts, Input parameters, Computation and Summary. First column is the parameters; the following columns are values of those parameters in US and English units, as well as the multiplication factor to convert from US units to Metric units.

\section{A. Input parameters}

A screenshot of the input parameters is shown in the Appendix D. Different product type will have different values for these parameters. The user needs to define product and process parameters prior to the computation for heat losses. These are also the most common and most important parameters that will define the characteristics of the product type and its related process set-up which in turn determines the energy consumption when producing that product.

Pot length, width, height, and temperatures are process parameters. Line speed, coating weight, strip width and thickness are product parameters.

\section{B. Computation}

This is the main body of the program where all the computations take place. Snapshots of the computation section are shown in Appendix D. Users input the values for every required parameters and the program will automatically compute and display the results accordingly in appropriate cells.

There are totally 8 main heat losses occurring during the production as well as downtime in the pot.

- Heat loss from surface

- Heat loss through the bottom

- Heat loss through the walls:

- Heat conduction (absorption) from strip 
- Heat required to melt zinc ingot and maintain zinc bath temperature

- Heat required to melt Al-Zn ingot and maintain zinc bath temperature

- Heat loss due to air knife cooling effect.

- Zinc coating heat loss

- Dross removal heat loss

\section{Summary}

This section summarizes the summation of main heat losses taking place during production and downtime for the main pot and pre-melt pot. A screenshot of the Summary is shown in the Appendix D.

\subsubsection{Mass balance}

This section summarizes the amount of material coming in and out of the system. A screenshot of the Mass balance worksheet is shown in Appendix D.

\subsubsection{Heat balance}

This worksheet presents the heat balance of the main pot in two cases: with and without the pre-melt pot.

A screenshot of the Heat balance worksheet is shown in Appendix D.

The heat balance summarizes all the heat losses occurring in the main pot. It balances the heat input and output of the system.

\subsubsection{Summary}

This worksheet summarizes all the heat losses as well as the total heat loss for the main pot and pre-melt pot during production and downtime.

A screenshot of the Summary worksheet is shown in Appendix D.

\subsubsection{Dross}

This worksheet presents the background computation for the heat loss due to dross removal every period of time during the production. Dross builds up on the surface of the 
pot and need to be removed to maintain the stability of the pot and quality of the galvanized products.

It takes the temperature of the dross as well as the amount of each substance constituting the dross as input. The result is the amount of heat loss from this dross.

A screenshot of the Dross worksheet is shown in Appendix D.

\subsubsection{Ingot}

This worksheet shows the background computation for the heat required to melt the ingots and maintain the zinc bath temperature. Ingots include pure zinc and Al-Zn alloy which are added every hour to the main or pre-melt pot.

It import data from the Pot model worksheet such as the temperatures of the ingots before and after melting as well as the amount of ingots being put into the pot every hour. The program calculates the energy required to melt and put the temperature of the melted ingots up to zinc bath temperature.

A screenshot of the Ingot worksheet is shown in Appendix D.

\subsubsection{Strip}

This worksheet shows the background computation for the heat absorption or conduction from the steel strip to the pot. The computation takes some product parameters as input from Pot model worksheet and gives output in terms of energy.

A screenshot of the Strip worksheet is shown in Appendix D.

\subsubsection{Zinc coating}

This worksheet contains the background computation for the heat loss due to zinc coating on the strip surface. It imports some product data such as line speed, strip width and coating weight to first calculate the amount of zinc coated on the strip surface and then computes the energy associated with the solidification process of the zinc coating.

A screenshot of the Zinc coating worksheet is shown in Appendix D. 


\subsubsection{Excessive zinc}

This worksheet contains the background computation for the amount of heat loss from the cooling effect of excessive zinc coming back to the pot.

A screenshot of the Excessive zinc worksheet is shown in Appendix D.

\subsubsection{Background}

This presents the background computation for the heat convection coefficient for the heat loss due to convection from the pot surface.

A screenshot of the Background worksheet is shown in Appendix D.

\subsubsection{Reference}

This worksheet shows the reference for the calculation of heat content of several metals and gas.

A screenshot of the Reference worksheet is shown in Appendix D.

\subsection{Conclusion}

Heat transfer mechanisms of the heat losses for the pot presented in the heat balance are basic heat transfer concepts (i.e. radiation, convection, conduction, and specific heat). Depending on the nature of heat losses, the configurations of the pot and the process, different heat transfer mechanisms can be applied. According to the conservation of energy, energy is only being transferred from one place to another. Therefore, heat input should be equal to heat output. After all heat losses were recognized and heat balance equations were established, an Excel ${ }^{\circledR}$ model for the heat balance has been generated. This Excel ${ }^{\circledR}$ model is based on heat balance equations which accounts for all heat losses and heat input. The program consists of 9 worksheets: Pot model, Summary, Heat balance, Dross, Ingot, Strip, Zinc coating, Background, and Reference. 


\section{CHAPTER 4: MODEL EXECUTION AND SENSITIVITY ANALYSIS}

\subsection{Model execution}

The model was applied using the data collected from a host company during the plant visit. The calculations were done utilizing these data.

\subsubsection{Heat loss from the pot surface}

\section{a) Convection:}

The temperature distribution on the pot surface is assumed to be uniform (i.e. average temperature is used). In this facility, it is measured and averaged to be $820^{\circ} \mathrm{F}$.

$\mathrm{T}_{\mathrm{s}}=820{ }^{0} \mathrm{~F}$

$\mathrm{T}_{\mathrm{a}}=75^{0} \mathrm{~F}$

Length $=13 \mathrm{ft}$

Width $=11 \mathrm{ft}$

$\mathrm{A}=143 \mathrm{ft}^{2}$

Heat convection coefficient can be calculated from the given temperatures of the surface and ambient using steps below.

First, the average temperature $T_{f}$ of $T_{s}$ and $T_{a}$ needs to be calculated.

$$
\begin{aligned}
T_{f} & =\frac{\left(\frac{T_{s}-32}{1.8}+\frac{T_{a}-32}{1.8}\right)}{2} \\
& =\frac{\left(\frac{820-32}{1.8}+\frac{75-32}{1.8}\right)}{2}=230.83{ }^{\circ} \mathrm{C}
\end{aligned}
$$

Using the value of $T_{f}$, other factors required to determine the heat convection coefficient are computed.

$$
k=\frac{\left(T_{f}-200\right)(0.045-0.039)}{(300-200)}+0.039
$$




$$
\begin{aligned}
& =\frac{(230.83-200)(0.045-0.039)}{(300-200)}+0.039 \\
& =0.041 \\
& \frac{g \beta}{v \alpha}=\frac{\left(T_{f}-200\right)(4.96-9.53)}{300-200}+9.53 \\
& =\frac{(230.83-200)(4.96-9.53)}{300-200}+9.53 \\
& =8.12 \\
& L \quad=\frac{\text { length } \times \text { width }}{2(\text { length }+ \text { width })} \\
& =\frac{13 \times 0.3048 \times 11 \times 0.3048}{2(13 \times 0.3048+11 \times 0.3048)} \\
& =0.908 \mathrm{~m} \\
& R a=\frac{g \beta}{v \alpha}\left(T_{s}-T_{a}\right)(L \times 100)^{3} \\
& =8.12 \times(90.8)^{3} \times\left(\frac{820-32}{1.8}-\frac{75-32}{1.8}\right) \\
& =2,515,922,983 \\
& N u \quad=0.15 \times\left(R a L^{\frac{1}{3}}\right) \\
& =0.15 \times\left(2,515,922,983^{\frac{1}{3}}\right) \\
& =204.013
\end{aligned}
$$

Then, the heat convection coefficient can be calculated from the formula given below.

$$
h \quad=\frac{N u \times k}{L}
$$




$$
\begin{aligned}
& =\frac{204.013 \times 0.041}{0.908} \\
& =9.21 \mathrm{~W} / \mathrm{m} .{ }^{0} \mathrm{C} \\
h & =9.21 / 5.6785 \\
& =1.62 \mathrm{Btu} / \mathrm{hr} . \mathrm{ft}^{2} .{ }^{0} \mathrm{~F}
\end{aligned}
$$

After heat convection coefficient has been determined, heat loss by convection can be computed using the given formula.

$$
\begin{aligned}
Q \quad & =h A\left(T_{s}-T_{a}\right) \\
& =1.62 \times 143 \times(820-75) \\
& =172,828 \mathrm{Btu} / \mathrm{hr} \\
& =0.17 \mathrm{MMBtu} / \mathrm{hr}
\end{aligned}
$$

\section{b) Radiation}

Although it is known that there is a combination of metals, metal oxide and metallic compounds floating on the surface of the pot, the emissivities of the pot surface materials are assumed to have one value which represents the heat radiation on the surface. It is determined to be 0.3 for this facility.

$\mathcal{E}=0.3$

$\mathrm{B}=0.1714 \times 10^{-8} \mathrm{Btu} / \mathrm{h} . \mathrm{ft}^{2}{ }^{0} \mathrm{R}^{4}$

$\mathrm{A}=143 \mathrm{ft}^{2}$

$\mathrm{T}_{\mathrm{s}}=820{ }^{0} \mathrm{~F}=1279{ }^{0} \mathrm{R}$

$\mathrm{T}_{\mathrm{a}}=75{ }^{0} \mathrm{~F}=534.7{ }^{0} \mathrm{R}$

The heat loss by radiation can be computed using the given formula.

$$
\begin{aligned}
Q \quad & =\varepsilon B A\left(T_{s}^{4}-T_{a}^{4}\right) \\
& =0.3 \times 0.1714 \times 10^{-8} \times 143 \times\left(1279.6^{4}-534.7^{4}\right) \\
& =191,170 \mathrm{Btu} / \mathrm{hr}
\end{aligned}
$$


$=0.19 \mathrm{MMBtu} / \mathrm{hr}$

\subsubsection{Heat loss through the bottom by heat conduction}

In this facility, the pot is constructed with two insulating materials at the bottom. These two insulation layers have different thicknesses and thermal conductivities. From the technical drawings of the pot, materials and dimensions of the pot as well as insulation layers are determined.

$\mathrm{t}_{\mathrm{p}}=0.15 \mathrm{ft}$

$\mathrm{t}_{1}=0.4 \mathrm{ft}$

$\mathrm{t}_{2}=0.6 \mathrm{ft}$

$\mathrm{k}_{\mathrm{p}}=20 \mathrm{Btu} / \mathrm{hr} . \mathrm{ft} .{ }^{0} \mathrm{~F}$

$\mathrm{k}_{1}=0.15 \mathrm{Btu} / \mathrm{hr} . \mathrm{ft} .{ }^{0} \mathrm{~F}$

$\mathrm{k}_{2}=0.4 \mathrm{Btu} / \mathrm{hr} . \mathrm{ft} .{ }^{0} \mathrm{~F}$

$\mathrm{A}=143 \mathrm{ft}^{2}$

$\mathrm{T}_{\mathrm{p}}=870{ }^{0} \mathrm{~F}$

$\mathrm{T}_{\mathrm{b}}=100{ }^{0} \mathrm{~F}$

The calculation for the heat loss is shown below.

$$
\begin{aligned}
Q \quad & =\frac{A\left(T_{p}-T_{b}\right)}{\left(\frac{t_{p}}{k_{p}}+\frac{t_{1}}{k_{1}}+\frac{t_{2}}{k_{2}}\right)} \\
& =\frac{143 \times(870-100)}{\left(\frac{0.15}{20}+\frac{0.4}{0.15}+\frac{0.6}{0.4}\right)} \\
& =26,349 \mathrm{Btu} / \mathrm{hr} \\
& =0.03 \mathrm{MMBtu} / \mathrm{hr}
\end{aligned}
$$




\subsubsection{Heat loss through the walls of the pot}

\section{a) Convection}

In this facility, pot is submerged under the ground. Natural convection takes place at the walls, so it is assumed to be $1 \mathrm{Btu} / \mathrm{hr}^{-\mathrm{ft}^{2}} .{ }^{0} \mathrm{~F}$.

$\mathrm{h} \quad=1 \mathrm{Btu} / \mathrm{hr} \cdot \mathrm{ft}^{2} .{ }^{0} \mathrm{~F}$

A $\quad=336 \mathrm{ft}^{2}$

$\mathrm{T}_{\mathrm{w}} \quad=235^{0} \mathrm{~F}$

$\mathrm{T}_{\mathrm{a}}=75^{0} \mathrm{~F}$

The calculation for the heat loss is shown below.

$$
\begin{aligned}
Q_{h} \quad & =h A\left(T_{w}-T_{a}\right) \\
& =1 \times 336 \times(235-75) \\
& =53,760 \mathrm{Btu} / \mathrm{hr}
\end{aligned}
$$

\section{b) Radiation}

From the pot hardware's configuration, the material of the walls has the value of 0.3 for emissivity.

$$
\begin{aligned}
\mathcal{E} & =0.3 \\
\mathrm{~B} & =0.1714 \times 10^{-8} \text { Btu/h.ft } .{ }^{0} \mathrm{R}^{4} \\
\mathrm{~A} & =336 \mathrm{ft}^{2} \\
\mathrm{~T}_{\mathrm{w}} & =235{ }^{0} \mathrm{~F}=694.67{ }^{0} \mathrm{R} \\
\mathrm{T}_{\mathrm{a}} & =75{ }^{0} \mathrm{~F}=534.67{ }^{0} \mathrm{R} \\
Q_{r} & =\varepsilon B A\left(T_{w}^{4}-T_{a}^{4}\right) \\
& =0.3 \times 0.1714 \times 10^{-8} \times 336 \times\left(694.67^{4}-534.67^{4}\right) \\
& =52,228 \mathrm{Btu} / \mathrm{hr}
\end{aligned}
$$

Finally, the total heat loss through walls is: 


$$
\begin{aligned}
\backslash Q \quad & =Q_{h}+Q_{r} \\
& =53,760+52,228 \\
& =105,988 \mathrm{Btu} / \mathrm{hr} \\
& =0.1 \mathrm{MMBtu} / \mathrm{hr}
\end{aligned}
$$

\subsubsection{Heat absorption/conduction from steel strip}

Steel strip is coming into the pot at the speed of $423 \mathrm{ft} / \mathrm{min}$, with a temperature of $863^{0} \mathrm{~F}$ and exiting the pot with a temperature of $870^{\circ} \mathrm{F}$.

Line speed $\quad=423 \mathrm{ft} / \mathrm{min}$

Density of steel $\quad=490 \mathrm{lbs} / \mathrm{ft}^{3}$

Strip width $\quad=4.3 \mathrm{ft}$

Strip thickness $\quad=0.00208 \mathrm{ft}$

Strip entry temperature $\quad=863^{\circ} \mathrm{F}=735^{\circ} \mathrm{K}$

Strip exit temperature $\quad=870^{\circ} \mathrm{F}=739^{\circ} \mathrm{K}$

The amount of Fe per hour is coming into the pot can be determined from the set up.

Mass flow rate of strip $=423 \times 490 \times 4.3 \times 0.00208 \times 60$

$=111,229 \mathrm{lbs} / \mathrm{hr}$

Amount of Fe

$=111,229 \frac{\mathrm{lbs}}{\mathrm{hr}} \times \frac{1 \mathrm{lb} \mathrm{mol}}{55.85 \mathrm{lbs}} \times \frac{1 \mathrm{~kg}}{2.2 \mathrm{lbs}}=905 \frac{\mathrm{kg} \cdot \mathrm{mol}}{\mathrm{hr}}$

The amounts of heat that is going to and out of the pot are calculated as shown below.

Sensible heat of $\mathrm{Fe}$ at $735^{\circ} \mathrm{K}$ :

$$
\begin{aligned}
\mathrm{H}_{735}-\mathrm{H}_{298} & =\frac{3.37 \times 735+0.00355 \times 735^{2}-0.0000043 \times 735^{-1}-1176}{1000} \\
& =3.22 \frac{\mathrm{Mcal}}{\mathrm{kg} . \mathrm{mol}}
\end{aligned}
$$

Potential heat of $\mathrm{Fe}$ at $735^{\circ} \mathrm{K}=3.22 \times 905$

$$
=2912.38 \mathrm{Mcal} / \mathrm{hr}
$$

Sensible heat of Fe at $739^{\circ} \mathrm{K}$ : 


$$
\begin{aligned}
\mathrm{H}_{739}-\mathrm{H}_{298} & =\frac{3.37 \times 739+0.00355 \times 739^{2}-0.0000043 \times 739^{-1}-1176}{1000} \\
& =3.25 \frac{\mathrm{Mcal}}{\mathrm{kg} \cdot \mathrm{mol}}
\end{aligned}
$$

Potential heat of Fe at $739^{0} \mathrm{~K}=3.25 \times 905$

$$
=2942.66 \mathrm{Mcal} / \mathrm{hr}
$$

Potential heat gain of $\mathrm{Fe} \quad=2942.66-2912.38$

$$
\begin{aligned}
& =30.28 \mathrm{Mcal} / \mathrm{hr} \\
& =0.12 \mathrm{MMBtu} / \mathrm{hr}
\end{aligned}
$$

Heat absorption of steel strip from the pot $=0.12 \mathrm{MMBtu} / \mathrm{hr}$

\subsubsection{Heat required to melt ingots and maintain pot temperature}

In this facility, ingots are added every hour with pure zinc ingot and Al-Zn ingot (at room temperature).

Amount of pure zinc ingot added $\quad=3294 \mathrm{lbs} / \mathrm{hr}$

Amount of $\mathrm{Al}$ in Al-Zn alloy ingot added $=9 \mathrm{lbs} / \mathrm{hr}$

Amount of $\mathrm{Zn}$ in Al-Zn alloy ingot added $=81 \mathrm{lbs} / \mathrm{hr}$

Initial temperature of ingots $\quad=75^{\circ} \mathrm{F}=297.04^{0} \mathrm{~K}$

Final temperature of ingots $\quad=870^{\circ} \mathrm{F}=738.71^{\circ} \mathrm{K}$

Atomic mass of $\mathrm{Al} \quad=26.98$

Atomic mass of $\mathrm{Zn} \quad=65.38$

Amount of pure Zn ingot $\quad=3294 \frac{\mathrm{lbs}}{\mathrm{hr}} \times \frac{1 \mathrm{lb} \mathrm{mol}}{65.38 \mathrm{lbs}} \times \frac{1 \mathrm{~kg}}{2.2 \mathrm{lbs}}=22.90 \frac{\mathrm{kg} \cdot \mathrm{mol}}{\mathrm{hr}}$

Amount of Al in Al-Zn alloy ingot $=9 \frac{\mathrm{lbs}}{\mathrm{hr}} \times \frac{1 \mathrm{lb} \mathrm{mol}}{26.98 \mathrm{lbs}} \times \frac{1 \mathrm{~kg}}{2.2 \mathrm{lbs}}=0.15 \frac{\mathrm{kg} \cdot \mathrm{mol}}{\mathrm{hr}}$

Amount of $\mathrm{Zn}$ in Al-Zn alloy ingot $=81 \frac{\mathrm{lbs}}{\mathrm{hr}} \times \frac{1 \mathrm{lb} \mathrm{mol}}{65.38 \mathrm{lbs}} \times \frac{1 \mathrm{~kg}}{2.2 \mathrm{lbs}}=0.56 \frac{\mathrm{kg} \cdot \mathrm{mol}}{\mathrm{hr}}$

Energy of ingots are being put into the pot are computed as shown below.

Sensible heat of pure $\mathrm{Zn}$ ingot at $297.04^{0} \mathrm{~K}$ : 


$$
\begin{aligned}
\mathrm{H}_{297.04-\mathrm{H}_{298}} & =\frac{5.35 \times 297.04+0.0012 \times 297.04^{2}-1702}{1000} \\
& \cong-0.01 \frac{\mathrm{Mcal}}{\mathrm{kg} \cdot \mathrm{mol}}
\end{aligned}
$$

Potential heat of pure $\mathrm{Zn}$ ingot at $297.04^{0} \mathrm{~K}=-0.01 \times 22.90$

$$
=-0.16 \mathrm{Mcal} / \mathrm{hr}
$$

Sensible heat of pure $\mathrm{Zn}$ ingot at $738.71^{0} \mathrm{~K}$ :

$$
\begin{aligned}
\mathrm{H}_{738.71}-\mathrm{H}_{298} & =\frac{7.5 \times 738.71-850}{1000} \\
& =4.69 \frac{\mathrm{Mcal}}{\mathrm{kg} \cdot \mathrm{mol}}
\end{aligned}
$$

Potential heat of pure $\mathrm{Zn}$ ingot at $738.71^{0} \mathrm{~K}=4.69 \times 22.90$

$$
=107.41 \mathrm{Mcal} / \mathrm{hr}
$$

Amount of energy needed to melt pure zinc ingot and maintain the pot temperature is calculated as shown below.

Potential gain of pure $\mathrm{Zn}$ ingot

$$
\begin{aligned}
& =107.41-(-0.16) \\
& =107.57 \frac{\mathrm{Mcal}}{\mathrm{hr}} \\
& =0.43 \mathrm{MMBtu} / \mathrm{hr}
\end{aligned}
$$

Sensible heat of $\mathrm{Al}$ in $\mathrm{Al}-\mathrm{Zn}$ ingot at $297.04^{0} \mathrm{~K}$ :

$$
\begin{aligned}
\mathrm{H}_{297.04-\mathrm{H}_{298}} & =\frac{4.94 \times 297.04+0.00148 \times 297.04^{2}-1605}{1000} \\
& \cong-0.01 \frac{\mathrm{Mcal}}{\mathrm{kg} \cdot \mathrm{mol}}
\end{aligned}
$$

Potential heat of $\mathrm{Al}$ in $\mathrm{Al}-\mathrm{Zn}$ ingot at $297.04^{0} \mathrm{~K}=-0.01 \times 0.15$

$$
=0 \mathrm{Mcal} / \mathrm{hr}
$$

Sensible heat of $\mathrm{Al}$ in Al-Zn ingot at $738.71^{\circ} \mathrm{K}$ :

$$
\begin{aligned}
\mathrm{H}_{738.71}-\mathrm{H}_{298} & =\frac{7 \times 738.71+330}{1000} \\
& =5.50 \frac{\mathrm{Mcal}}{\mathrm{kg} \cdot \mathrm{mol}}
\end{aligned}
$$


Potential heat of $\mathrm{Al}$ in $\mathrm{Al}-\mathrm{Zn}$ ingot at $738.71^{0} \mathrm{~K} \quad=5.50 \times 0.15$

$$
=0.83 \mathrm{Mcal} / \mathrm{hr}
$$

Amount of energy needed to melt $\mathrm{Al}$ in $\mathrm{Al}-\mathrm{Zn}$ ingot and maintain the pot temperature is calculated as shown below.

Potential gain of $\mathrm{Al}$ in $\mathrm{Al}-\mathrm{Zn}$ ingot

$$
\begin{aligned}
& =0.83-0 \\
& =0.83 \frac{\mathrm{Mcal}}{\mathrm{hr}} \\
& =0 \mathrm{MMBtu} / \mathrm{hr}
\end{aligned}
$$

Sensible heat of $\mathrm{Zn}$ in Al-Zn ingot at $297.04^{0} \mathrm{~K}$ :

$$
\begin{aligned}
\mathrm{H}_{297.04}-\mathrm{H}_{298} & =\frac{5.35 \times 297.04+0.0012 \times 297.04^{2}-1702}{1000} \\
& \cong-0.01 \frac{\mathrm{Mcal}}{\mathrm{kg} \cdot \mathrm{mol}}
\end{aligned}
$$

Potential heat of $\mathrm{Zn}$ in Al- $\mathrm{Zn}$ ingot at $297.04^{0} \mathrm{~K}=-0.01 \times 0.56$

$$
=0 \mathrm{Mcal} / \mathrm{hr}
$$

Sensible heat of $\mathrm{Zn}$ in $\mathrm{Al}-\mathrm{Zn}$ ingot at $738.71^{0} \mathrm{~K}$ :

$$
\begin{aligned}
\mathrm{H}_{738.71}-\mathrm{H}_{298} & =\frac{7.5 \times 738.71-850}{1000} \\
& =4.69 \frac{\mathrm{Mcal}}{\mathrm{kg} \cdot \mathrm{mol}}
\end{aligned}
$$

Potential heat of $\mathrm{Zn}$ in Al-Zn ingot at $738.71^{0} \mathrm{~K} \quad=4.69 \times 0.56$

$$
=2.64 \mathrm{Mcal} / \mathrm{hr}
$$

Amount of energy needed to melt $\mathrm{Zn}$ in $\mathrm{Al}-\mathrm{Zn}$ ingot and maintain the pot temperature is calculated as shown below.

Potential gain of $\mathrm{Zn}$ in Al-Zn ingot

$$
\begin{aligned}
& =2.64-0 \\
& =2.64 \frac{\mathrm{Mcal}}{\mathrm{hr}} \\
& =0.01 \mathrm{MMBtu} / \mathrm{hr}
\end{aligned}
$$




\subsubsection{Heat loss due to air knife cooling effect}

Heat convection coefficient is determined to be $9,69 \mathrm{Btu} / \mathrm{hr}^{-\mathrm{ft}^{2}}{ }^{0}{ }^{0} \mathrm{~F}$. Air knife is operated at $157^{0} \mathrm{~F}$, and at height of $2.5 \mathrm{ft}$ (from the pot surface).

$$
\begin{aligned}
& \mathrm{h}=9.69 \mathrm{Btu} / \mathrm{hr} \cdot \mathrm{ft}^{2} \cdot{ }^{0} \mathrm{~F} \\
& \mathrm{~T}_{\mathrm{s}}=820{ }^{0} \mathrm{~F} \\
& \mathrm{~T}_{\mathrm{wp}}=157{ }^{0} \mathrm{~F} \\
& \mathrm{~h}_{\mathrm{a}}=2.5 \mathrm{ft} \\
& \mathrm{l}_{\mathrm{c}}=1.6 \mathrm{ft} \\
& \mathrm{w}=4.3 \mathrm{ft}
\end{aligned}
$$

The heat loss from air knife cooling effect is calculated as shown below.

$$
\begin{aligned}
Q \quad & =2 \mathrm{hw}\left(\mathrm{T}_{\mathrm{s}}-\mathrm{T}_{\mathrm{wp}}\right)\left(\mathrm{h}_{\mathrm{a}}+\mathrm{l}_{\mathrm{c}}\right) \\
& =2 \times 9.69 \times 4.3 \times(820-157) \times(2.5+1.6) \\
& =226,423 \mathrm{Btu} / \mathrm{hr} \\
& =0.2 \mathrm{MMBtu} / \mathrm{hr}
\end{aligned}
$$

\subsubsection{Heat loss from zinc coating}

At the time of data collection, the plant is producing a G60 product with a coating weight of $0.6 \mathrm{oz} / \mathrm{ft}^{2}$. Input parameters are given below.

Coating weight $\quad=0.6 \mathrm{oz} / \mathrm{ft}^{2}$

Width of strip $\quad=4.3 \mathrm{ft}$

Line speed $\quad=423 \mathrm{ft} / \mathrm{min}$

Temperature of $\mathrm{Zn}($ in pot $)=870^{\circ} \mathrm{F}=738.71^{0} \mathrm{~K}$

The amount of zinc being drawn from the pot per hour can be calculated as shown below.

Coating weight loss $=0.6 \times 4.3 \times 423 \times 60 \times 0.0625$

$$
=4093 \mathrm{lbs} / \mathrm{hr}
$$


Amount of $\mathrm{Zn} \quad=4093 \frac{\mathrm{lbs}}{\mathrm{hr}} \times \frac{1 \mathrm{lb} \mathrm{mol}}{65.38 \mathrm{lbs}} \times \frac{1 \mathrm{~kg}}{2.2 \mathrm{lbs}}=28.45 \frac{\mathrm{kg} \cdot \mathrm{mol}}{\mathrm{hr}}$

Then, the amount of energy from zinc loss can be determined as shown below.

Sensible heat of $\mathrm{Zn}$ at $738.71^{0} \mathrm{~K}$ :

$$
\begin{aligned}
\mathrm{H}_{738.71}-\mathrm{H}_{298} & =\frac{7.5 \times 738.71-850}{1000} \\
& =4.69 \frac{\mathrm{Mcal}}{\mathrm{kg} \cdot \mathrm{mol}}
\end{aligned}
$$

Potential heat of $\mathrm{Zn}$ at $738.71^{0} \mathrm{~K} \quad=4.69 \times 28.45$

$$
\begin{aligned}
& =133.45 \mathrm{Mcal} / \mathrm{hr} \\
& =0.53 \mathrm{MMBtu} / \mathrm{hr}
\end{aligned}
$$

\subsubsection{Heat loss from dross removal}

Dross is skimmed every hour to maintain the pot stability and quality of zinc coating on the strip surface. The amount of dross is given.

Amount of dross $\quad=300 \mathrm{lbs} / \mathrm{hr}$

The amounts of substances compositing dross need to be determined in order to calculate the heat loss from dross being removed from pot surface.

Percentage of Fe in Al-Fe-Zn alloy $=2 \%=6 \mathrm{lbs} / \mathrm{hr}$

Percentage of Al in Al-Fe-Zn alloy $=3 \%=9 \mathrm{lbs} / \mathrm{hr}$

Percentage of $\mathrm{Zn}$ in Al-Fe-Zn alloy $=95 \%=285 \mathrm{lbs} / \mathrm{hr}$

Average temperature of dross needs to be assumed or estimated to determine heat loss.

Average temperature of dross $\quad=572$ degree $\mathrm{F}=573.15^{0} \mathrm{~K}$

Amount of Fe $\quad=6 \frac{\mathrm{lbs}}{\mathrm{hr}} \times \frac{1 \mathrm{lb} \mathrm{mol}}{55.85 \mathrm{lbs}} \times \frac{1 \mathrm{~kg}}{2.2 \mathrm{lbs}}=0.05 \frac{\mathrm{kg} \cdot \mathrm{mol}}{\mathrm{hr}}$

Amount of $\mathrm{Al}=9 \frac{\mathrm{lbs}}{\mathrm{hr}} \times \frac{1 \mathrm{lb} \mathrm{mol}}{26.98 \mathrm{lbs}} \times \frac{1 \mathrm{~kg}}{2.2 \mathrm{lbs}}=0.15 \frac{\mathrm{kg} \cdot \mathrm{mol}}{\mathrm{hr}}$

Amount of $\mathrm{Zn} \quad=285 \frac{\mathrm{lbs}}{\mathrm{hr}} \times \frac{1 \mathrm{lb} \mathrm{mol}}{65.38 \mathrm{lbs}} \times \frac{1 \mathrm{~kg}}{2.2 \mathrm{lbs}}=1.98 \frac{\mathrm{kg} \cdot \mathrm{mol}}{\mathrm{hr}}$

Then, the amount of heat loss from dross removal can be computed as shown below. 
Sensible heat of $\mathrm{Fe}$ at $573.15^{\circ} \mathrm{K}$ :

$$
\begin{aligned}
\mathrm{H}_{573.15}-\mathrm{H}_{298} & =\frac{3.37 \times 573.15+0.00355 \times 573.15^{2}-0.0000043 \times 573.15^{-1}-1176}{1000} \\
& =1.92 \frac{\mathrm{Mcal}}{\mathrm{kg} . \mathrm{mol}}
\end{aligned}
$$

Potential heat of $\mathrm{Fe}$ at $573.15^{0} \mathrm{~K}=1.92 \times 0.05$

$$
=0.09 \mathrm{Mcal} / \mathrm{hr}
$$

Sensible heat of $\mathrm{Al}$ at $573.15^{0} \mathrm{~K}$ :

$$
\begin{aligned}
\mathrm{H}_{573.15}-\mathrm{H}_{298} & =\frac{4.94 \times 573.15+0.00148 \times 573.15^{2}-1605}{1000} \\
& =1.71 \frac{\mathrm{Mcal}}{\mathrm{kg} \cdot \mathrm{mol}}
\end{aligned}
$$

Potential heat of $\mathrm{Al}$ at $573.15^{\circ} \mathrm{K} \quad=1.71 \times 0.15$

$$
=0.26 \mathrm{Mcal} / \mathrm{hr}
$$

Sensible heat of $\mathrm{Zn}$ at $573.15^{\circ} \mathrm{K}$ :

$$
\begin{aligned}
\mathrm{H}_{573.15}-\mathrm{H}_{298} & =\frac{5.35 \times 573.15+0.0012 \times 573.15^{2}-1702}{1000} \\
& =1.76 \frac{\mathrm{Mcal}}{\mathrm{kg} . \mathrm{mol}}
\end{aligned}
$$

Potential heat of $\mathrm{Al}$ at $573.15^{0} \mathrm{~K}=1.76 \times 1.98$

$$
=3.48 \mathrm{Mcal} / \mathrm{hr}
$$

Potential heat of dross

$$
\begin{aligned}
& =0.09+0.260 .09+0.26+3.48 \\
& =3.84 \frac{\text { Mcal }}{\mathrm{hr}} \\
& =0.02 \mathrm{MMBtu} / \mathrm{hr}
\end{aligned}
$$

\subsubsection{Heat loss due to excessive zinc:}

Amount of excessive $\mathrm{Zn}$

Initial temperature of the $\mathrm{Zn}$

Final temperature of excessive $\mathrm{Zn}$

$$
=1000 \mathrm{lbs} / \mathrm{hr}
$$

$$
=870^{\circ} \mathrm{F}=738.71^{0} \mathrm{~K}
$$

$$
=700^{0} \mathrm{~F}=644.26^{0} \mathrm{~K}
$$


Atomic mass of $\mathrm{Zn}$

Amount of excessive $\mathrm{Zn}$

$$
=65.38
$$

$$
=1000 \frac{\mathrm{lbs}}{\mathrm{hr}} \times \frac{1 \mathrm{lb} \mathrm{mol}}{65.38 \mathrm{lbs}} \times \frac{1 \mathrm{~kg}}{2.2 \mathrm{lbs}}=6.95 \frac{\mathrm{kg} \cdot \mathrm{mol}}{\mathrm{hr}}
$$

Sensible heat of excessive $\mathrm{Zn}$ at $738.71^{\circ} \mathrm{K}$ :

$$
\begin{aligned}
\mathrm{H}_{297.04}-\mathrm{H}_{298} & =\frac{5.35 \times 738.71+0.0012 \times 738.71^{2}-1702}{1000} \\
& \cong 4.69 \frac{\mathrm{Mcal}}{\mathrm{kg} . \mathrm{mol}}
\end{aligned}
$$

Potential heat of excessive $\mathrm{Zn}$ at $738.71^{0} \mathrm{~K}=4.69 \times 6.95$

$$
=32.61 \mathrm{Mcal} / \mathrm{hr}
$$

Sensible heat of excessive $\mathrm{Zn}$ at $644.26^{0} \mathrm{~K}$ :

$$
\begin{aligned}
\mathrm{H}_{738.71}-\mathrm{H}_{298} & =\frac{7.5 \times 644.26-850}{1000} \\
& =3.98 \frac{\mathrm{Mcal}}{\mathrm{kg} \cdot \mathrm{mol}}
\end{aligned}
$$

Potential heat of excessive $\mathrm{Zn}$ at $738.71^{0} \mathrm{~K}=3.98 \times 6.95$

$$
=27.68 \mathrm{Mcal} / \mathrm{hr}
$$

Potential gain of excessive $\mathrm{Zn}$

$$
\begin{aligned}
& =27.68-(32.61) \\
& =-4.92 \frac{\mathrm{Mcal}}{\mathrm{hr}} \\
& =-0.02 \mathrm{MMBtu} / \mathrm{hr}
\end{aligned}
$$




\subsection{Sensitivity analysis}

\section{a. Volume of the pot}

\section{Table 3: Scenarios of different dimensions}

\begin{tabular}{|c|c|c|c|c|}
\hline & Scenario 1 & Scenario 2 & Scenario 3 & Unit \\
\hline Length & 13 & 10 & 13 & $\mathrm{ft}$ \\
\hline Width & 11 & 11 & 9 & $\mathrm{ft}$ \\
\hline Height & 7 & 7 & 7 & $\mathrm{ft}$ \\
\hline
\end{tabular}

This sensitivity is to see the effect of changing the dimensions of the main pot on the total heat loss. In this sensitivity analysis, the length and width of the pot have been decreased in the Scenario 2 and 3 respectively.

As we can see, reducing the volume of the pot by reducing the value of one of the dimensions of the pot such as height or width leads to a decrease in total heat loss in the main pot during production as well as downtime. The smaller the pot is, the less heat loss will be.

\section{Table 4: Result of total heat losses for different scenarios}

\begin{tabular}{|c|c|c|c|c|}
\hline Heat losses & Case A & Case B & Case C & Unit \\
\hline Heat loss from the surface & 363,372 & 279,517 & 297,304 & $\mathrm{Btu} / \mathrm{hr}$ \\
\hline Heat loss through the bottom & 26,349 & 20,269 & 21,558 & $\mathrm{Btu} / \mathrm{hr}$ \\
\hline Heat loss through the walls & 105,988 & 92,739 & 97,156 & $\mathrm{Btu} / \mathrm{hr}$ \\
\hline Heat conduction (absorption) from the steel strip & 120,149 & 120,149 & 120,149 & $\mathrm{Btu} / \mathrm{hr}$ \\
\hline Heat required to melt added ingots and & & & & \\
\hline maintain the zinc bath temperature & 570,568 & 440,657 & 440,657 & $\mathrm{Btu} / \mathrm{hr}$ \\
\hline Heat loss due to air knife cooling effect & 226,422 & 226,422 & 226,422 & $\mathrm{Btu} / \mathrm{hr}$ \\
\hline Heat loss from zinc coating & 529,536 & 529,536 & 529,536 & $\mathrm{Btu} / \mathrm{hr}$ \\
\hline Heat loss from dross removal & 45,831 & 45,831 & 45,831 & $\mathrm{Btu} / \mathrm{hr}$ \\
\hline Heat loss due to excessive zinc & 19,541 & 19,541 & 19,541 & $\mathrm{Btu} / \mathrm{hr}$ \\
\hline & & & & \\
\hline Total heat loss & & & & \\
\hline Main pot & 1.44 & 1.33 & 1.36 & $\mathrm{MMBtu} / \mathrm{hr}$ \\
\hline Pre - melt pot & 0.57 & 0.44 & 0.44 & $\mathrm{MMBtu} / \mathrm{hr}$ \\
\hline Downtime (Main pot) & 0.50 & 0.39 & 0.42 & $\mathrm{MMBtu} / \mathrm{hr}$ \\
\hline
\end{tabular}


Below is the graph showing the total heat losses for 3 scenarios.

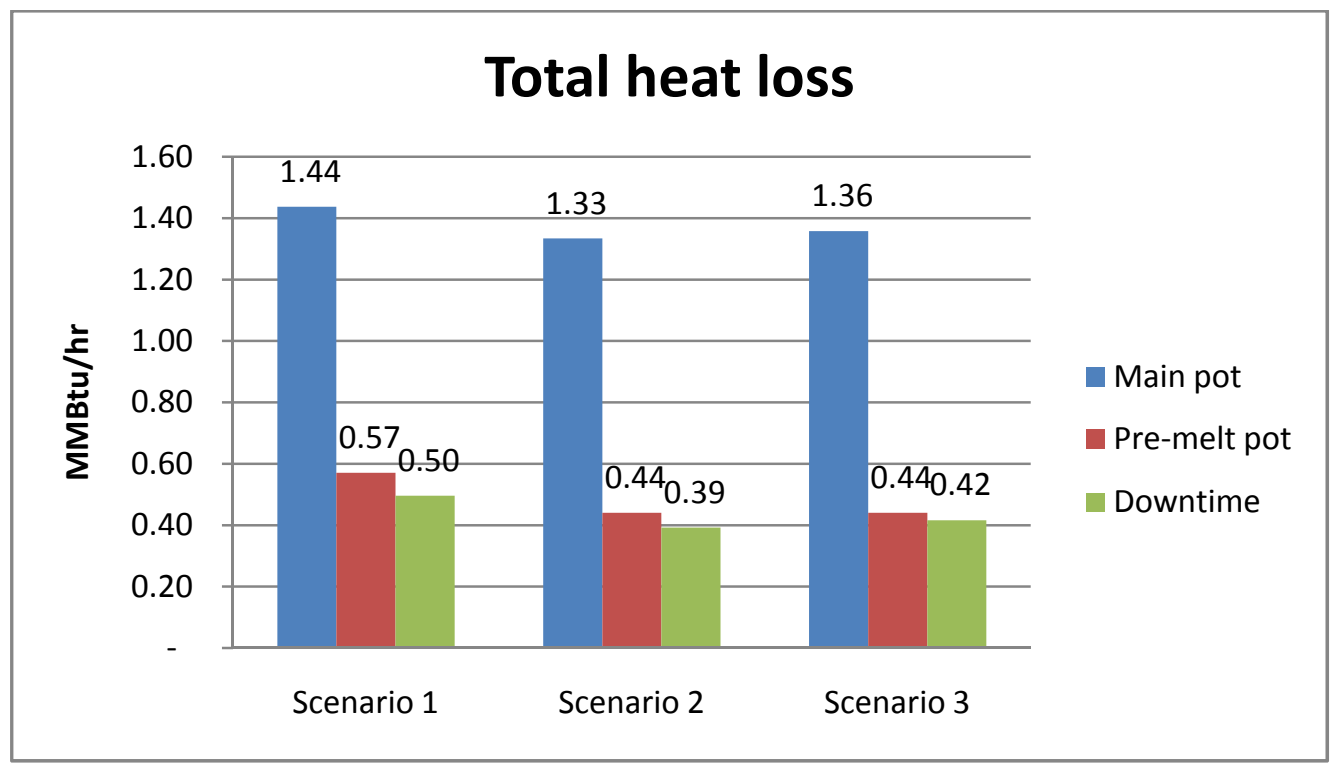

Figure 20: Total heat loss versus Scenarios of different pot dimensions

\section{b. Pot temperature}

Table 5: Scenarios of different pot temperatures

\begin{tabular}{|c|c|c|c|c|}
\hline & Scenario 1 & Scenario 2 & Scenario 3 & Unit \\
\hline Pot temperature & 870 & 850 & 890 & degree F \\
\hline
\end{tabular}

The sensitivity is carried out by changing the temperature to see the effects on the total heat losses.

It can be seen that when the pot temperature decreases, total heat losses for main pot and pre-melt pot decrease. Total heat losses will increase as the pot temperature increases because more heat will be radiated and convected. 
Table 6: Result of total heat losses for different scenarios

\begin{tabular}{|c|c|c|c|c|}
\hline Heat losses & Case A & Case B & Case C & Unit \\
\hline Heat loss from the surface & 363,372 & 363,372 & 363,372 & $\mathrm{Btu} / \mathrm{hr}$ \\
\hline Heat loss through the bottom & 26,349 & 25,665 & 27,034 & $\mathrm{Btu} / \mathrm{hr}$ \\
\hline Heat loss through the walls & 105,988 & 105,988 & 105,988 & $\mathrm{Btu} / \mathrm{hr}$ \\
\hline Heat conduction (absorption) from the steel strip & 120,149 & $(222,110)$ & 465,557 & $\mathrm{Btu} / \mathrm{hr}$ \\
\hline Heat required to melt added ingots and & & & & \\
\hline maintain the zinc bath temperature & 570,568 & 432,851 & 448,462 & $\mathrm{Btu} / \mathrm{hr}$ \\
\hline Heat loss due to air knife cooling effect & 226,422 & 226,422 & 226,422 & $\mathrm{Btu} / \mathrm{hr}$ \\
\hline Heat loss from zinc coating & 529,536 & 520,127 & 538,944 & $\mathrm{Btu} / \mathrm{hr}$ \\
\hline Heat loss from dross removal & 45,831 & 45,831 & 45,831 & $\mathrm{Btu} / \mathrm{hr}$ \\
\hline Heat loss due to excessive zinc & 19,541 & 17,242 & 21,840 & $\mathrm{Btu} / \mathrm{hr}$ \\
\hline & & & & \\
\hline Total heat loss & & & & \\
\hline Main pot & 1.44 & 1.08 & 1.79 & $\mathrm{MMBtu} / \mathrm{hr}$ \\
\hline Pre - melt pot & 0.57 & 0.43 & 0.45 & $\mathrm{MMBtu} / \mathrm{hr}$ \\
\hline Downtime (Main pot) & 0.50 & 0.50 & 0.50 & $\mathrm{MMBtu} / \mathrm{hr}$ \\
\hline
\end{tabular}

Below is the graph showing the total heat losses for 3 scenarios.

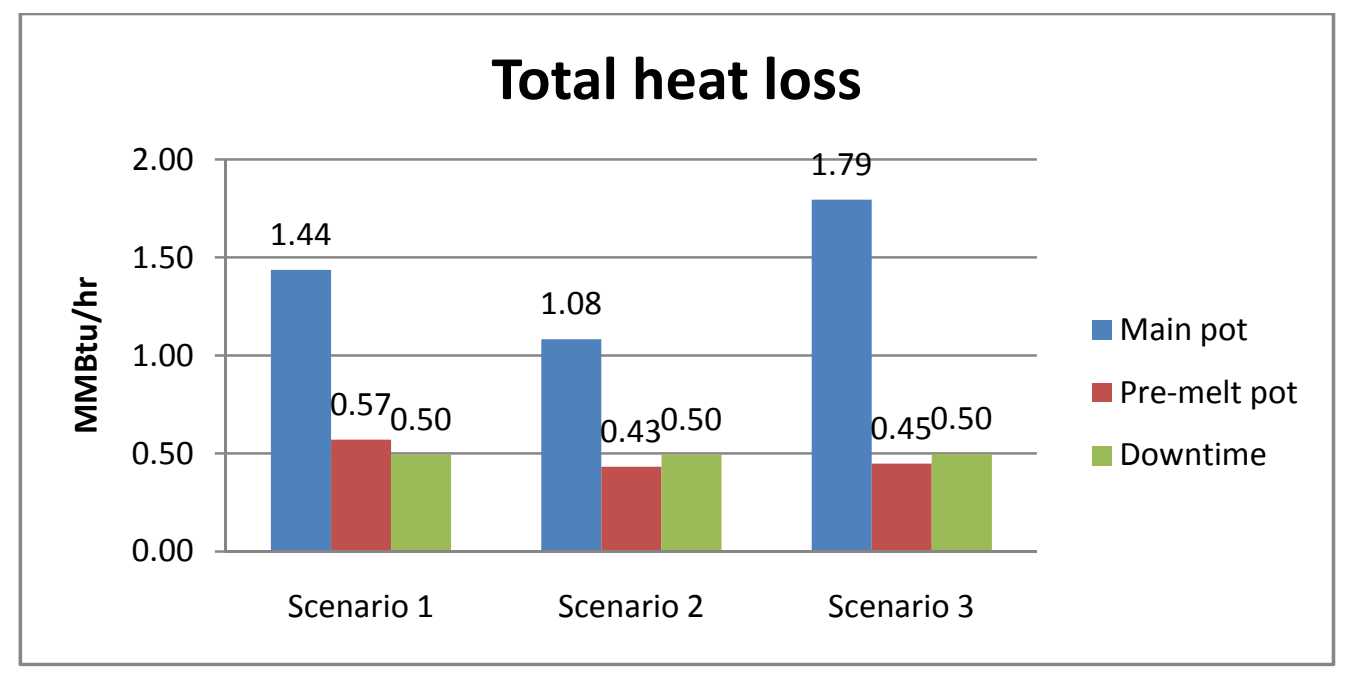

Figure 21: Total heat loss versus Scenarios of different pot temperatures

\section{c. Ambient temperature}

\section{Table 7: Scenarios of different ambient temperatures}

\begin{tabular}{|c|c|c|c|c|}
\hline & Scenario 1 & Scenario 2 & Scenario 3 & Unit \\
\hline Ambient temperature & 75 & 90 & 65 & degree F \\
\hline
\end{tabular}


This sensitivity is to show the effect of changing ambient temperature on the total heat losses. The result shows that when ambient temperature decreases the heat losses tend to increase and vice versa. This is probably due to the temperature difference between the ambient and the pot. The lower temperature of ambient will make the pot lose more heat to the ambient.

Table 8: Result of total heat losses for different scenarios

\begin{tabular}{|c|c|c|c|c|}
\hline Heat losses & Case A & Case B & Case C & Unit \\
\hline Heat loss from the surface & 363,372 & 357,758 & 367,087 & $\mathrm{Btu} / \mathrm{hr}$ \\
\hline Heat loss through the bottom & 26,349 & 26,349 & 26,349 & $\mathrm{Btu} / \mathrm{hr}$ \\
\hline Heat loss through the walls & 105,988 & 97,643 & 111,402 & $\mathrm{Btu} / \mathrm{hr}$ \\
\hline Heat conduction (absorption) from the steel strip & 120,149 & 120,149 & 120,149 & $\mathrm{Btu} / \mathrm{hr}$ \\
\hline Heat required to melt added ingots and & & & & \\
\hline maintain the zinc bath temperature & 570,568 & 435,916 & 443,809 & $\mathrm{Btu} / \mathrm{hr}$ \\
\hline Heat loss due to air knife cooling effect & 226,422 & 226,422 & 226,422 & $\mathrm{Btu} / \mathrm{hr}$ \\
\hline Heat loss from zinc coating & 529,536 & 529,536 & 529,536 & $\mathrm{Btu} / \mathrm{hr}$ \\
\hline Heat loss from dross removal & 45,831 & 45,831 & 45,831 & $\mathrm{Btu} / \mathrm{hr}$ \\
\hline Heat loss due to excessive zinc & 19,541 & 19,541 & 19,541 & $\mathrm{Btu} / \mathrm{hr}$ \\
\hline & & & & \\
\hline Total heat loss & & & & \\
\hline Main pot & 1.44 & 1.42 & 1.45 & $\mathrm{MMBtu} / \mathrm{hr}$ \\
\hline Pre - melt pot & 0.57 & 0.44 & 0.44 & $\mathrm{MMBtu} / \mathrm{hr}$ \\
\hline Downtime (Main pot) & 0.50 & 0.48 & 0.50 & $\mathrm{MMBtu} / \mathrm{hr}$ \\
\hline
\end{tabular}

Below is the graph showing the total heat losses for 3 scenarios.

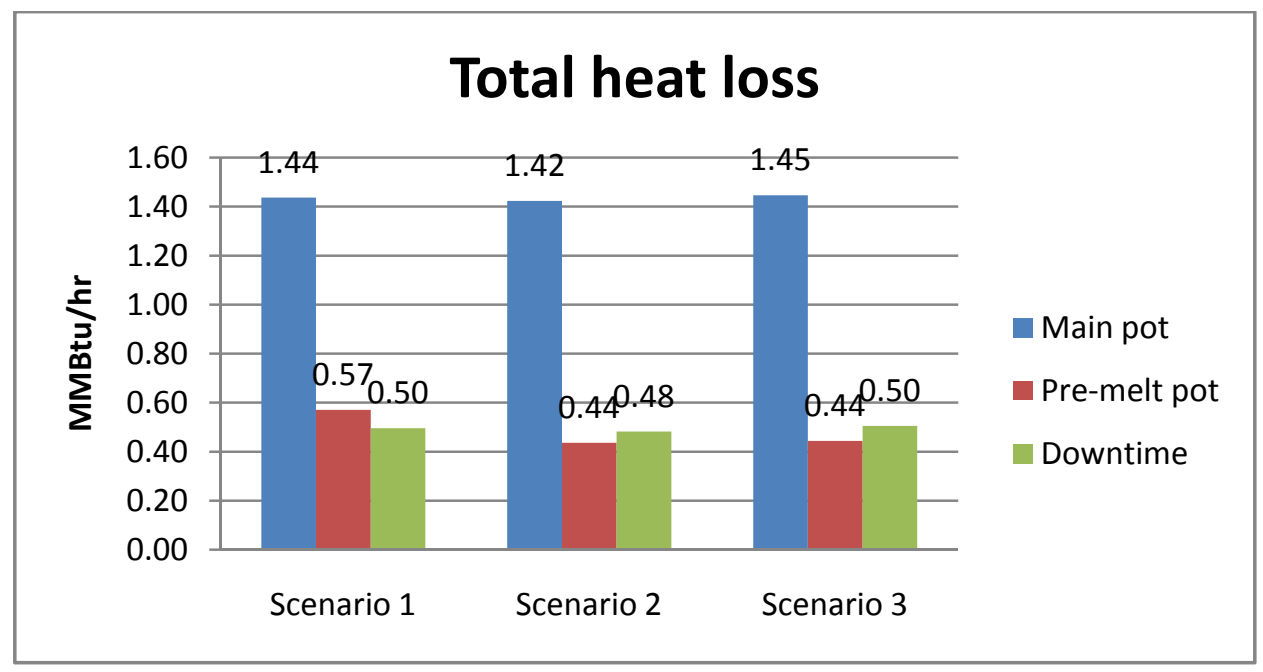

Figure 22: Total heat loss versus Scenarios of different ambient temperatures 


\section{d. Emissivity}

Table 9: Scenarios of different emissivities

\begin{tabular}{|c|c|c|c|}
\hline & Scenario 1 & Scenario 2 & Scenario 3 \\
\hline Emissivity (surface) & 0.3 & 0.4 & 0.2 \\
\hline
\end{tabular}

This sensitivity is to analyze the effect of changing the emissivity for the surface of the main pot on the total heat loss. The increased emissivity will increase heat losses in the main pot and vice versa.

Table 10: Result of total heat losses for different scenarios

\begin{tabular}{|c|c|c|c|c|}
\hline Heat losses & Case A & Case B & Case C & Unit \\
\hline Heat loss from the surface & 363,372 & 427,095 & 299,648 & $\mathrm{Btu} / \mathrm{hr}$ \\
\hline Heat loss through the bottom & 26,349 & 26,349 & 26,349 & $\mathrm{Btu} / \mathrm{hr}$ \\
\hline Heat loss through the walls & 105,988 & 105,988 & 105,988 & $\mathrm{Btu} / \mathrm{hr}$ \\
\hline Heat conduction (absorption) from the steel strip & 120,149 & 120,149 & 120,149 & $\mathrm{Btu} / \mathrm{hr}$ \\
\hline Heat required to melt added ingots and & & & & \\
\hline maintain the zinc bath temperature & 570,568 & 440,657 & 440,657 & $\mathrm{Btu} / \mathrm{hr}$ \\
\hline Heat loss due to air knife cooling effect & 226,422 & 226,422 & 226,422 & $\mathrm{Btu} / \mathrm{hr}$ \\
\hline Heat loss from zinc coating & 529,536 & 529,536 & 529,536 & $\mathrm{Btu} / \mathrm{hr}$ \\
\hline Heat loss from dross removal & 45,831 & 45,831 & 45,831 & $\mathrm{Btu} / \mathrm{hr}$ \\
\hline Heat loss due to excessive zinc & 19,541 & 19,541 & 19,541 & $\mathrm{Btu} / \mathrm{hr}$ \\
\hline Total heat loss & & & & \\
\hline Main pot & & & & \\
\hline Pre - melt pot & 1.44 & 1.50 & 1.37 & $\mathrm{MMBtu} / \mathrm{hr}$ \\
\hline Downtime (Main pot) & 0.57 & 0.44 & 0.44 & $\mathrm{MMBtu} / \mathrm{hr}$ \\
\hline & 0.50 & 0.56 & 0.43 & $\mathrm{MMBtu} / \mathrm{hr}$ \\
\hline
\end{tabular}


Below is the graph showing the total heat losses for 3 scenarios.

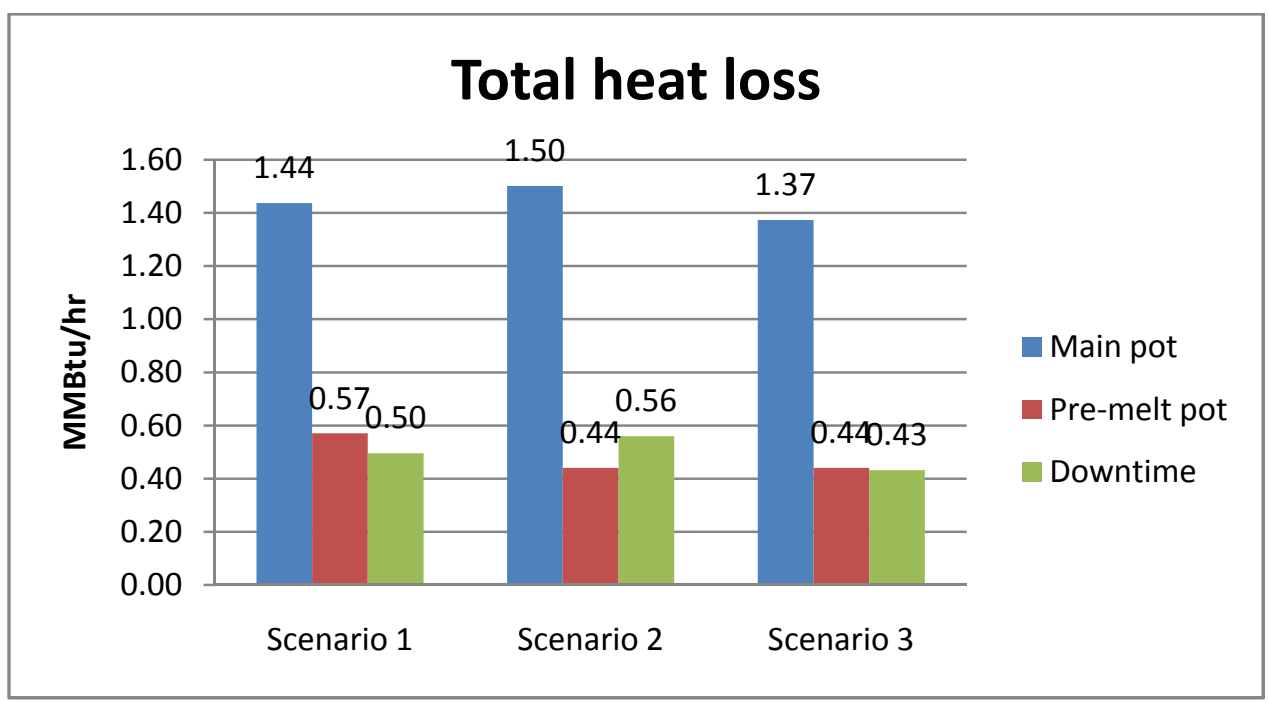

Figure 23: Total heat loss versus Scenarios of different emissivities

\section{e. Thermal conductivity}

\section{Table 11: Scenarios of different conductivities}

\begin{tabular}{|c|c|c|c|c|}
\hline & Scenario 1 & Scenario 2 & Scenario 3 & Unit \\
\hline Pot & 20 & 30 & 20 & Btu/hr.ft.F \\
\hline Insulation 1 & 0.15 & 0.15 & 0.1 & Btu/hr.ft.F \\
\hline Insulation 2 & 0.4 & 0.4 & 0.4 & Btu/hr.ft.F \\
\hline
\end{tabular}

This sensitivity is done to see the effect of changing the thermal conductivities of the pot material as well as the insulating materials. The result shows that the thermal conductivity of the pot material has little effect on the total heat loss. The insulating materials play a bigger role because they determine the amount of heat radiated and convected to the atmosphere. 
Table 12: Result of total heat losses for different scenarios

\begin{tabular}{|c|c|c|c|c|}
\hline Heat losses & Case A & Case B & Case C & Unit \\
\hline Heat loss from the surface & 363,372 & 363,372 & 363,372 & $\mathrm{Btu} / \mathrm{hr}$ \\
\hline Heat loss through the bottom & 26,349 & 26,365 & 19,976 & $\mathrm{Btu} / \mathrm{hr}$ \\
\hline Heat loss through the walls & 105,988 & 105,988 & 105,988 & $\mathrm{Btu} / \mathrm{hr}$ \\
\hline Heat conduction (absorption) from the steel strip & 120,149 & 120,149 & 120,149 & $\mathrm{Btu} / \mathrm{hr}$ \\
\hline Heat required to melt added ingots and & & & & \\
\hline maintain the zinc bath temperature & 570,568 & 440,657 & 440,657 & $\mathrm{Btu} / \mathrm{hr}$ \\
\hline Heat loss due to air knife cooling effect & 226,422 & 226,422 & 226,422 & $\mathrm{Btu} / \mathrm{hr}$ \\
\hline Heat loss from zinc coating & 529,536 & 529,536 & 529,536 & $\mathrm{Btu} / \mathrm{hr}$ \\
\hline Heat loss from dross removal & 45,831 & 45,831 & 45,831 & $\mathrm{Btu} / \mathrm{hr}$ \\
\hline Heat loss due to excessive zinc & 19,541 & 19,541 & 19,541 & $\mathrm{Btu} / \mathrm{hr}$ \\
\hline & & & & \\
\hline Total heat loss & & & & \\
\hline Main pot & 1.44 & 1.44 & 1.43 & $\mathrm{MMBtu} / \mathrm{hr}$ \\
\hline Pre - melt pot & 0.57 & 0.44 & 0.44 & $\mathrm{MMBtu} / \mathrm{hr}$ \\
\hline Downtime (Main pot) & 0.50 & 0.50 & 0.49 & $\mathrm{MMBtu} / \mathrm{hr}$ \\
\hline
\end{tabular}

Below is the graph showing the total heat losses for 3 scenarios.

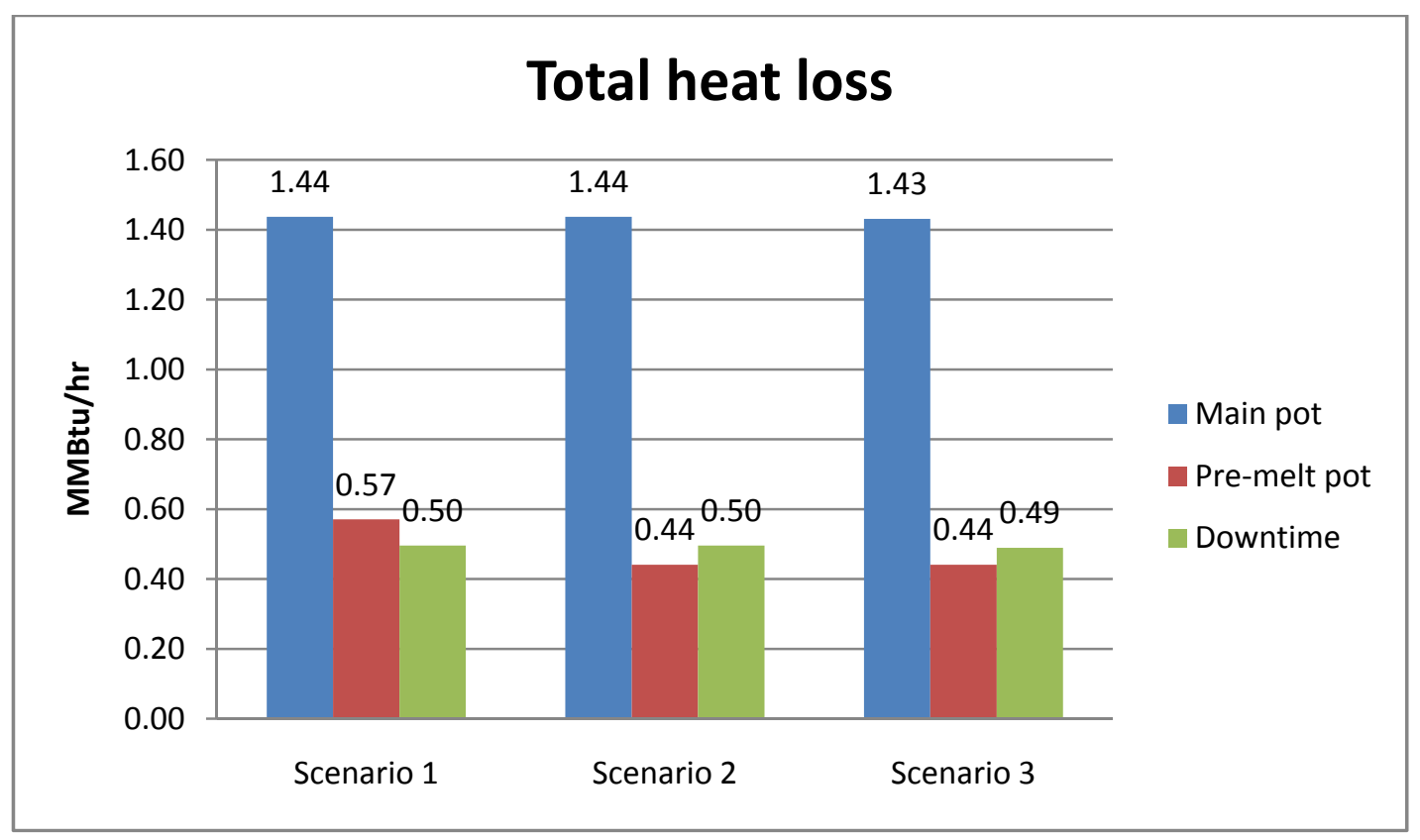

Figure 24: Total heat loss versus Scenarios of different thermal conductivities 


\section{f. Strip entry temperature}

Table 13: Scenarios of different strip entry temperatures

\begin{tabular}{|c|c|c|c|c|}
\hline & Scenario 1 & Scenario 2 & Scenario 3 & Unit \\
\hline Strip temperature (entry) & 863 & 860 & 875 & degree F \\
\hline
\end{tabular}

This sensitivity is to see the effect of changing the strip entry temperature on the total heat loss. As the strip is coming into the pot with lower temperature than the pot's temperature, it absorbs heat and gains temperature up to the pot's temperature. Therefore the result shows that the total heat loss for the main pot is higher for lower strip entry temperature.

As the strip is coming into the pot with a higher temperature than temperature of the pot, it provides heat to the pot. Therefore the total heat loss is smaller in this case.

Table 14: Result of total heat losses for different scenarios

\begin{tabular}{|c|c|c|c|c|}
\hline Heat losses & Case A & Case B & Case C & Unit \\
\hline Heat loss from the surface & 363,372 & 363,372 & 363,372 & $\mathrm{Btu} / \mathrm{hr}$ \\
\hline Heat loss through the bottom & 26,349 & 26,349 & 26,349 & $\mathrm{Btu} / \mathrm{hr}$ \\
\hline Heat loss through the walls & 105,988 & 105,988 & 105,988 & $\mathrm{Btu} / \mathrm{hr}$ \\
\hline Heat conduction (absorption) from the steel strip & 120,149 & 171,523 & $(86,057)$ & $\mathrm{Btu} / \mathrm{hr}$ \\
\hline Heat required to melt added ingots and & & & & \\
\hline maintain the zinc bath temperature & 570,568 & 440,657 & 440,657 & $\mathrm{Btu} / \mathrm{hr}$ \\
\hline Heat loss due to air knife cooling effect & 226,422 & 226,422 & 226,422 & $\mathrm{Btu} / \mathrm{hr}$ \\
\hline Heat loss from zinc coating & 529,536 & 529,536 & 529,536 & $\mathrm{Btu} / \mathrm{hr}$ \\
\hline Heat loss from dross removal & 45,831 & 45,831 & 45,831 & $\mathrm{Btu} / \mathrm{hr}$ \\
\hline Heat loss due to excessive zinc & 19,541 & 19,541 & 19,541 & $\mathrm{Btu} / \mathrm{hr}$ \\
\hline Total heat loss & & & & \\
\hline Main pot & & & & \\
\hline Pre - melt pot & 1.44 & 1.49 & 1.23 & $\mathrm{MMBtu} / \mathrm{hr}$ \\
\hline Downtime (Main pot) & 0.57 & 0.44 & 0.44 & $\mathrm{MMBtu} / \mathrm{hr}$ \\
\hline & 0.50 & 0.50 & 0.50 & $\mathrm{MMBtu} / \mathrm{hr}$ \\
\hline
\end{tabular}


Below is the graph showing the total heat losses for 3 scenarios.

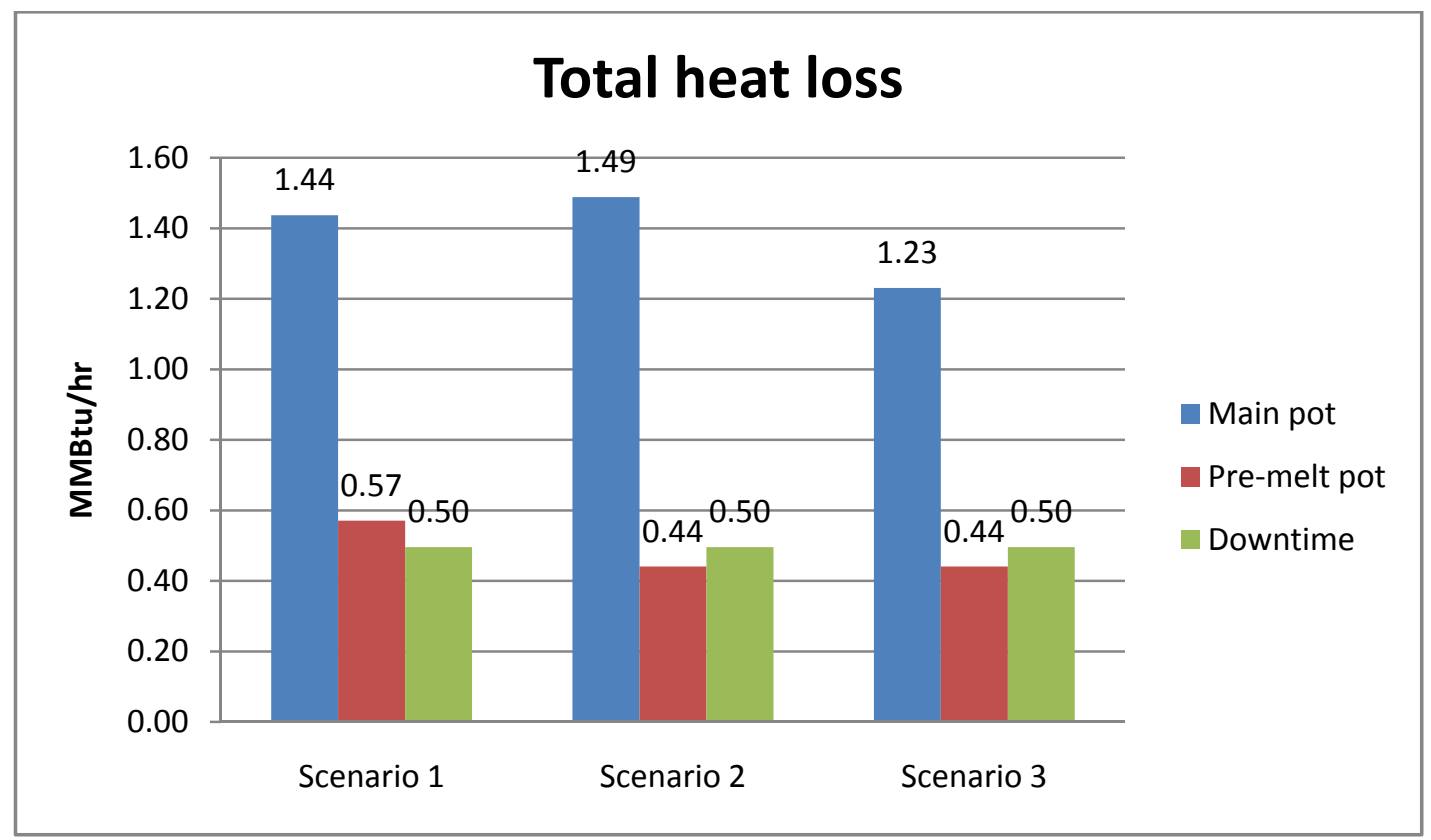

Figure 25: Total heat loss versus Scenarios of different strip entry temperatures

\section{g. Cooling length}

Table 15: Scenarios of different cooling lengths

\begin{tabular}{|c|c|c|c|c|}
\hline & Scenario 1 & Scenario 2 & Scenario 3 & Unit \\
\hline Cooling length & 1.6 & 2 & 1 & $\mathrm{ft}$ \\
\hline
\end{tabular}

This sensitivity is to study the effect of changing the cooling length on the total heat losses. As the cooling length increases, total heat loss in the main pot will increase. This is because more heat is convected from the pot surface due to the cooling effect of the air flow from air knives on the pot surface.

When cooling length decreases, total heat loss decreases due to smaller cooling effect from the air knives on the pot surface. 
Table 16: Result of total heat losses for different scenarios

\begin{tabular}{|c|c|c|c|c|}
\hline Heat losses & Case A & Case B & Case C & Unit \\
\hline Heat loss from the surface & 363,372 & 363,372 & 363,372 & $\mathrm{Btu} / \mathrm{hr}$ \\
\hline Heat loss through the bottom & 26,349 & 26,349 & 26,349 & $\mathrm{Btu} / \mathrm{hr}$ \\
\hline Heat loss through the walls & 105,988 & 105,988 & 105,988 & $\mathrm{Btu} / \mathrm{hr}$ \\
\hline Heat conduction (absorption) from the steel strip & 120,149 & 120,149 & 120,149 & $\mathrm{Btu} / \mathrm{hr}$ \\
\hline Heat required to melt added ingots and & & & & \\
\hline maintain the zinc bath temperature & 570,568 & 440,657 & 440,657 & $\mathrm{Btu} / \mathrm{hr}$ \\
\hline Heat loss due to air knife cooling effect & 226,422 & 248,512 & 193,287 & $\mathrm{Btu} / \mathrm{hr}$ \\
\hline Heat loss from zinc coating & 529,536 & 529,536 & 529,536 & $\mathrm{Btu} / \mathrm{hr}$ \\
\hline Heat loss from dross removal & 45,831 & 45,831 & 45,831 & $\mathrm{Btu} / \mathrm{hr}$ \\
\hline Heat loss due to excessive zinc & 19,541 & 19,541 & 19,541 & $\mathrm{Btu} / \mathrm{hr}$ \\
\hline & & & & \\
\hline Total heat loss & & & & \\
\hline Main pot & 1.44 & 1.46 & 1.40 & $\mathrm{MMBtu} / \mathrm{hr}$ \\
\hline Pre - melt pot & 0.57 & 0.44 & 0.44 & $\mathrm{MMBtu} / \mathrm{hr}$ \\
\hline Downtime (Main pot) & 0.50 & 0.50 & 0.50 & $\mathrm{MMBtu} / \mathrm{hr}$ \\
\hline
\end{tabular}

Below is the graph showing the total heat losses for 3 scenarios.

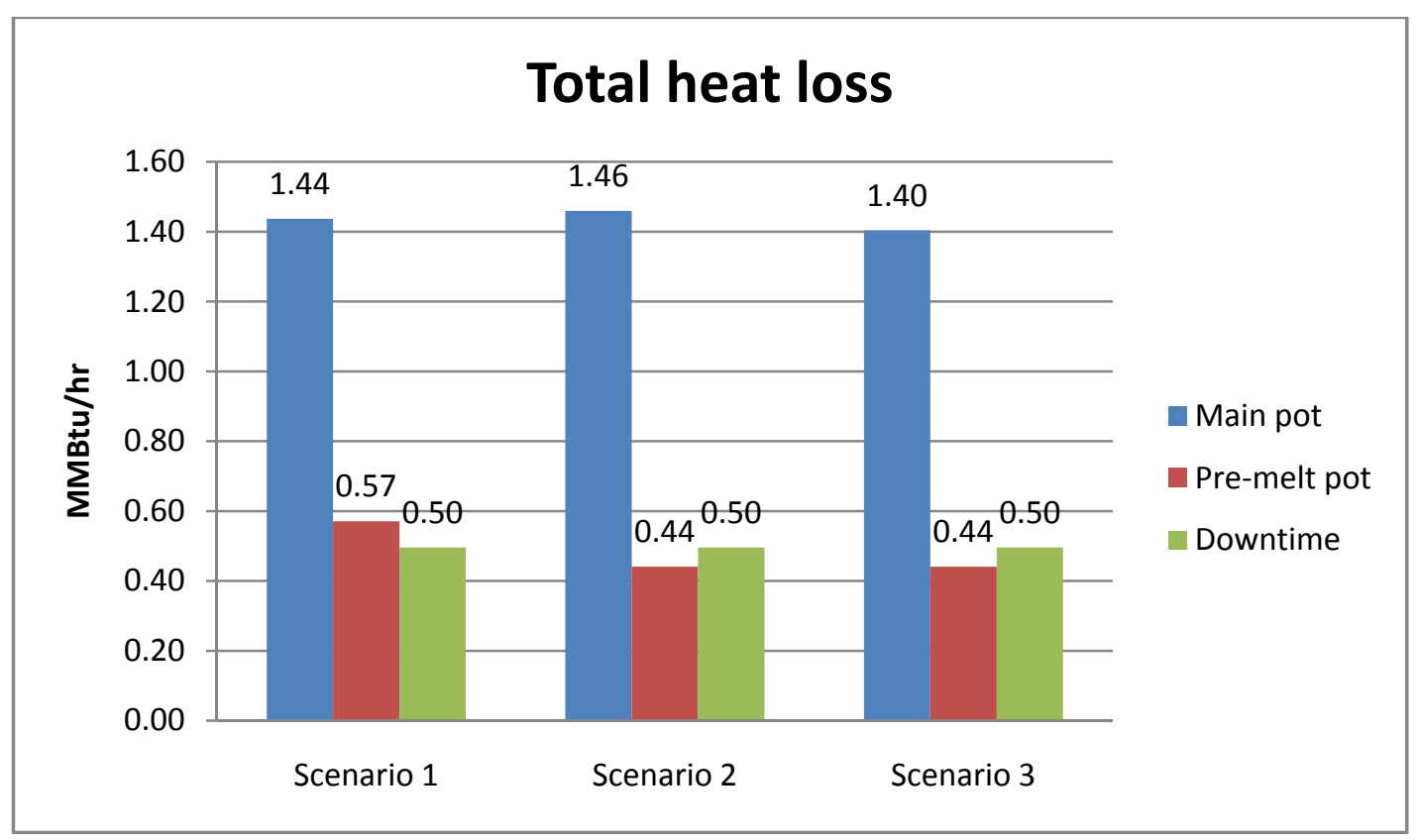

Figure 26: Total heat loss versus Scenarios of different cooling lengths 


\section{h. Wiping gas temperature}

Table 17: Scenarios of different wiping gas temperatures

\begin{tabular}{|c|c|c|c|c|}
\hline & Scenario 1 & Scenario 2 & Scenario 3 & Unit \\
\hline Wiping gas temperature & 157 & 140 & 180 & degree F \\
\hline
\end{tabular}

This sensitivity is done to see the effect of changing wiping gas temperature on total heat loss. When wiping gas temperature decreases, the air flow from air knives is "cooler", resulting in bigger cooling effect from the air knives. Therefore heat loss is bigger when wiping gas temperature is lower. In contrast, heat loss is smaller when wiping gas temperature is higher.

Table 18: Result of total heat losses for different scenarios

\begin{tabular}{|c|c|c|c|c|}
\hline Heat losses & Case A & Case B & Case C & Unit \\
\hline Heat loss from the surface & 363,372 & 363,372 & 363,372 & $\mathrm{Btu} / \mathrm{hr}$ \\
\hline Heat loss through the bottom & 26,349 & 26,349 & 26,349 & $\mathrm{Btu} / \mathrm{hr}$ \\
\hline Heat loss through the walls & 105,988 & 105,988 & 105,988 & $\mathrm{Btu} / \mathrm{hr}$ \\
\hline Heat conduction (absorption) from the steel strip & 120,149 & 120,149 & 120,149 & $\mathrm{Btu} / \mathrm{hr}$ \\
\hline Heat required to melt added ingots and & & & & \\
\hline maintain the zinc bath temperature & 570,568 & 440,657 & 440,657 & $\mathrm{Btu} / \mathrm{hr}$ \\
\hline Heat loss due to air knife cooling effect & 226,422 & 232,227 & 218,567 & $\mathrm{Btu} / \mathrm{hr}$ \\
\hline Heat loss from zinc coating & 529,536 & 529,536 & 529,536 & $\mathrm{Btu} / \mathrm{hr}$ \\
\hline Heat loss from dross removal & 45,831 & 45,831 & 45,831 & $\mathrm{Btu} / \mathrm{hr}$ \\
\hline Heat loss due to excessive zinc & 19,541 & 19,541 & 19,541 & $\mathrm{Btu} / \mathrm{hr}$ \\
\hline Total heat loss & & & & \\
\hline Main pot & & & & \\
\hline Pre - melt pot & 1.44 & 1.44 & 1.43 & $\mathrm{MMBtu} / \mathrm{hr}$ \\
\hline Downtime (Main pot) & 0.57 & 0.44 & 0.44 & $\mathrm{MMBtu} / \mathrm{hr}$ \\
\hline \multicolumn{2}{|c|}{0.50} & 0.50 & 0.50 & $\mathrm{MMBtu} / \mathrm{hr}$ \\
\hline
\end{tabular}


Below is the graph showing the total heat losses for 3 scenarios.

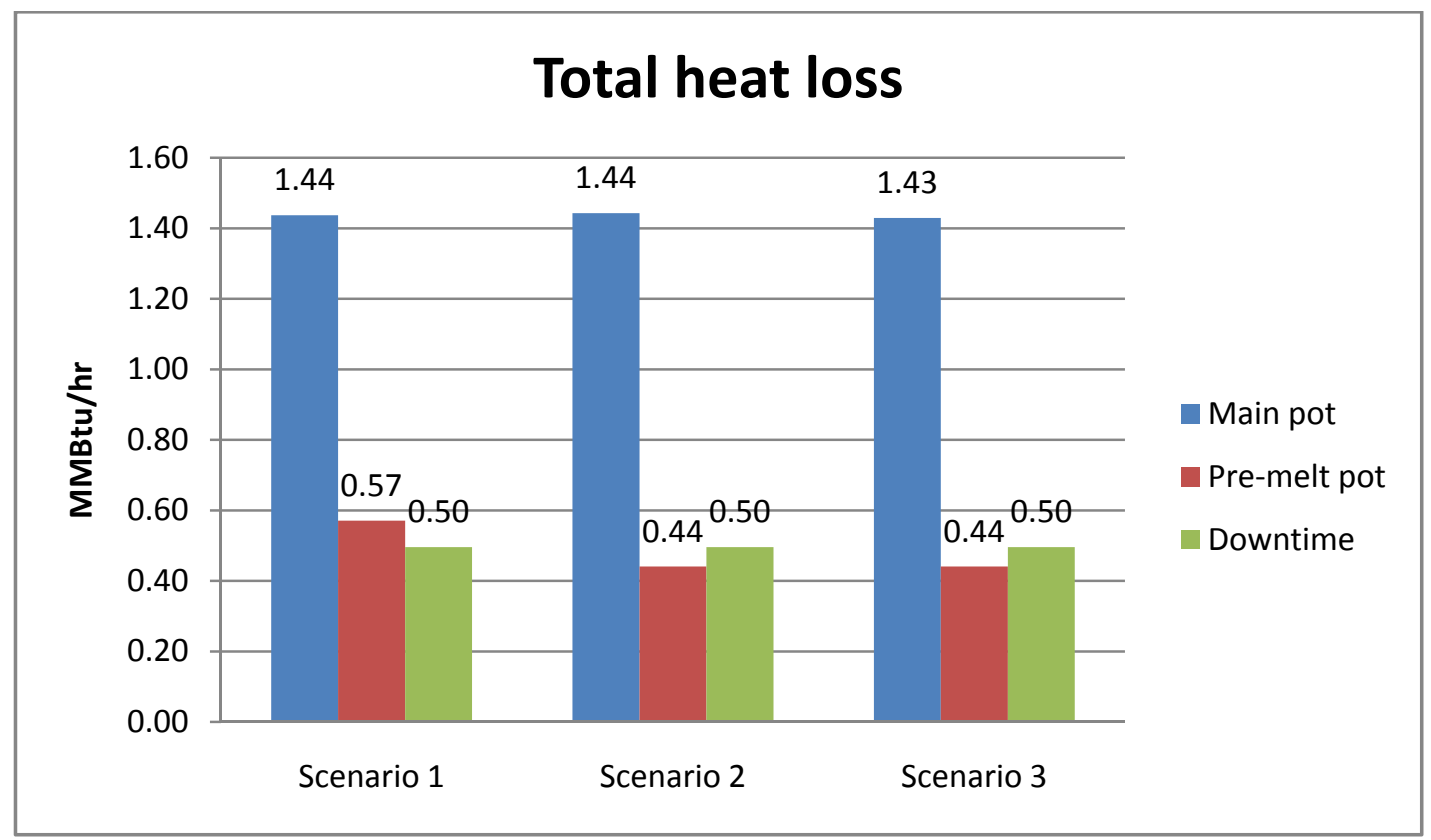

Figure 27: Total heat loss versus Scenarios of different wiping gas temperatures

\subsection{Conclusion}

The model was applied using the data collected from a host company during the plant visit. The calculations were done utilizing these data. Sensitivity analyses were done to study the impact of changing values of input parameters on the total heat loss of main pot and pre-melt pot during the production as well as downtime (for the main pot). 


\section{CHAPTER 5: RESULTS AND DISCUSSION}

\subsection{Run model}

The model was applied using a set of data for input parameters. The model was run and results were obtained. Below are the input parameters which were applied to model the heat balance of the pot.

Table 19: Input parameters

\begin{tabular}{|l|c|c|}
\hline \multicolumn{1}{|c|}{ Pot parameters } & \multicolumn{2}{c|}{ US units } \\
\hline Length & 13 & $\mathrm{ft}$ \\
\hline Width & 11 & $\mathrm{ft}$ \\
\hline Height & 7 & $\mathrm{ft}$ \\
\hline Pot temperature & 870 & ${ }^{0} \mathrm{~F}$ \\
\hline Pot surface temperature & 820 & ${ }^{0} \mathrm{~F}$ \\
\hline Ambient temperature & 75 & ${ }^{0} \mathrm{~F}$ \\
\hline Emissivity & 0.3 & \\
\hline Stephen Boltzmann constant & $1.714 \times 10^{-9}$ & $\mathrm{Btu} / \mathrm{hr} . \mathrm{ft}^{2} . \mathrm{R}^{4}$ \\
\hline Area of bottom & 143 & $\mathrm{ft}$ \\
\hline Temperature of bottom of the pot & 100 & ${ }^{0} \mathrm{~F}$ \\
\hline Insulation 1 thickness & 0.40 & $\mathrm{ft}$ \\
\hline Thermal conductivity of insulation 1 & 0.15 & $\mathrm{Btu} / \mathrm{hr} . \mathrm{ft} .{ }^{0} \mathrm{~F}$ \\
\hline Insulation 2 thickness & 0.60 & $\mathrm{ft}$ \\
\hline Thermal conductivity of insulation 2 & 0.40 & $\mathrm{Btu} / \mathrm{hr} . \mathrm{ft} .{ }^{0} \mathrm{~F}$ \\
\hline Thickness of pot material & 0.15 & $\mathrm{ft}$ \\
\hline Thermal conductivity of pot material & 20 & $\mathrm{Btu} / \mathrm{hr} . \mathrm{ft} .{ }^{0} \mathrm{~F}$ \\
\hline Total wall area & 336 & $\mathrm{ft}$ \\
\hline Temperature of walls & 235 & ${ }^{0} \mathrm{~F}$ \\
\hline Heat convection coefficient & 1 & $\mathrm{Btu} / \mathrm{hr} . \mathrm{ft}^{2} .{ }^{0} \mathrm{~F}$ \\
\hline Thickness of strip & 0.00208 & $\mathrm{ft}$ \\
\hline Width of strip & 4.3 & $\mathrm{ft}^{2}$ \\
\hline Density of strip & 490 & ${ }^{1 b} / \mathrm{ft}^{3}$ \\
\hline Line speed & 423 & $\mathrm{ft} / \mathrm{min}$ \\
\hline Specific heat capacity of strip & 0.115 & $\mathrm{Btu} / \mathrm{lb} .{ }^{0} \mathrm{~F}$ \\
\hline Strip temperature at entry & 863 & ${ }^{0} \mathrm{~F}$ \\
\hline & & ${ }^{0} \mathrm{~F}$ \\
\hline Strip temperature at exit & & \\
\hline
\end{tabular}




\begin{tabular}{|l|c|c|}
\hline Estimated amount of Zinc added & 4,000 & $1 \mathrm{bs} / \mathrm{hr}$ \\
\hline Initial temperature of added Zinc & 90 & ${ }^{0} \mathrm{~F}$ \\
\hline Estimated amount of 10\% Al-Zn alloy added & 350 & $1 \mathrm{bs} / \mathrm{hr}$ \\
\hline Initial temperature of added Al-Zn alloy & 90 & ${ }^{0} \mathrm{~F}$ \\
\hline Heat convection coefficient & 9.6855 & ${ }^{0} \mathrm{~F}$ \\
\hline Air knife height & 2.5 & $\mathrm{ft}$ \\
\hline Cooling length & 1.6 & $\mathrm{ft}$ \\
\hline Strip width & 4.3 & $\mathrm{ft}$ \\
\hline Wiping gas temperature & 157 & ${ }^{0} \mathrm{~F}$ \\
\hline Pot surface temperature & 820 & ${ }^{0} \mathrm{~F}$ \\
\hline
\end{tabular}

After the running the model, the results are shown below.

Table 20: Results after running the model

\begin{tabular}{|c|l|c|c|}
\hline 1 & Heat loss from the surface & 363,372 & $\mathrm{Btu} / \mathrm{hr}$ \\
\hline 2 & Heat loss through the bottom & 26,349 & $\mathrm{Btu} / \mathrm{hr}$ \\
\hline 3 & Heat loss through the walls & 105,988 & $\mathrm{Btu} / \mathrm{hr}$ \\
\hline 4 & Heat conduction (absorption) from the steel strip & 120,149 & $\mathrm{Btu} / \mathrm{hr}$ \\
\hline 5 & Heat required to melt added ingots and & & $\mathrm{Btu} / \mathrm{hr}$ \\
\hline & maintain the zinc bath temperature & 440,657 & $\mathrm{Btu} / \mathrm{hr}$ \\
\hline 6 & Heat loss due to air knife cooling effect & 226,422 & $\mathrm{Btu} / \mathrm{hr}$ \\
\hline 7 & Heat loss from zinc coating & 529,536 & $\mathrm{Btu} / \mathrm{hr}$ \\
\hline 8 & Heat loss from dross removal & 45,831 & $\mathrm{Btu} / \mathrm{hr}$ \\
\hline 9 & Heat loss due to excessive zinc & 19,541 & $\mathrm{Btu} / \mathrm{hr}$ \\
\hline & & & \\
\hline & Total heat loss & 1.44 & $\mathrm{MMBtu} / \mathrm{hr}$ \\
\hline & Main pot & 0.44 & $\mathrm{MMBtu} / \mathrm{hr}$ \\
\hline & Pre - melt pot & 0.50 & $\mathrm{MMBtu} / \mathrm{hr}$ \\
\hline & Downtime (Main pot) & & \\
\hline
\end{tabular}


Below are the snapshots of the program. Input parameters are required to input at the beginning of the worksheet to provide a general details about the product and process parameters. Followed by the Input parameters section is the Computation section. All heat losses are listed. After all the input cells are filled in, output cells will automatically display the calculated amounts of corresponding heat losses. There are some cells that are not required to fill because they will automatically display values accordingly after some input cells filled in. These cells are indicated in red font.

\begin{tabular}{|c|c|c|c|c|c|}
\hline B & c & D & E & $\mathrm{F}$ & G \\
\hline \multicolumn{6}{|l|}{ A. Input parameters } \\
\hline Product and Process parameters & \multicolumn{2}{|c|}{ US units } & $\begin{array}{c}\text { Multiplicative } \\
\text { conversion factor }\end{array}$ & \multicolumn{2}{|c|}{ Metric units } \\
\hline Pot length & 13 & $\mathrm{ft}$ & 0.3048 & 3.96 & $\mathrm{~m}$ \\
\hline Pot width & 11 & $\mathrm{ft}$ & 0.3048 & 3.35 & $\mathrm{~m}$ \\
\hline Pot height & 7 & $\mathrm{ft}$ & 0.3048 & 2.13 & $\mathrm{~m}$ \\
\hline Pot temperature & 870 & degree $\mathrm{F}$ & $\left({ }^{\circ} \mathrm{F}-32\right) \times 5 / 9$ & 465.56 & degree $\mathrm{C}$ \\
\hline \begin{tabular}{|l|} 
Pot surface temperature \\
\end{tabular} & 820 & degree $\mathrm{F}$ & $\left({ }^{\circ} \mathrm{F}-32\right) \times 5 / 9$ & 437.78 & degree $\mathrm{C}$ \\
\hline Ambient temperature & 75 & degree $\mathrm{F}$ & $\left({ }^{\circ} \mathrm{F}-32\right) \times 5 / 9$ & 23.89 & degree $\mathrm{C}$ \\
\hline Line speed & 423 & $\mathrm{ft} / \mathrm{min}$ & 0.3048 & 128.93 & $\mathrm{~m} / \mathrm{min}$ \\
\hline Coating weight & 0.6 & $\mathrm{oz} / \mathrm{ft} 2$ & 305.15 & 183.09 & $\mathrm{~g} / \mathrm{m} 2$ \\
\hline Strip width & 4.3 & $\mathrm{ft}$ & 0.3048 & 1.31 & $\mathrm{~m}$ \\
\hline Strip thickness & 0.00208 & $\mathrm{ft}$ & 0.3048 & 0.00 & $\mathrm{~m}$ \\
\hline \multicolumn{6}{|l|}{ B. Computation } \\
\hline \multirow{2}{*}{\multicolumn{6}{|c|}{ 1. Heat loss from surface of the Pot }} \\
\hline & & & & & \\
\hline Emissivity & 0.3 & & & & \\
\hline Stephen Boltzmann & $1.714 \mathrm{E}-09$ & Btu/h. $\cdot \mathrm{ft}^{2} \cdot{ }^{\circ} \mathrm{R}^{4}$ & & $5.67 \mathrm{E}-08$ & $\mathrm{~W} / \mathrm{m} 2 .{ }^{\circ} \mathrm{K} 4$ \\
\hline Radiation heat loss (surface) & $191,169.6$ & Btu/hr & .29 & 56,032 & w \\
\hline Convection heat loss (surface) & 175,971 & Btu/hr & .29 & 51,032 & w \\
\hline Heat loss from surface of the Pot & 367,141 & Btu/hr & .29 & 106,471 & w \\
\hline
\end{tabular}

Figure 28: Pot model worksheet screenshot

The heat loss from surface of the pot shows rather high value ( $\sim 0.4 \mathrm{MMBtu} / \mathrm{hr})$.

\begin{tabular}{|c|c|c|c|c|c|}
\hline \multicolumn{6}{|l|}{ 2. Heat loss through the bottom of the Pot } \\
\hline Area of bottom & 143 & $\mathrm{ft} 2$ & 0.093 & 13.29 & $\mathrm{~m} 2$ \\
\hline Temperature of pot & 870 & degree $\mathrm{F}$ & $\left({ }^{\circ} \mathrm{F}-32\right) \times 5 / 9$ & 465.56 & degree $\mathrm{C}$ \\
\hline Temperature of bottom of the pot & 100 & degree $\mathrm{F}$ & $\left({ }^{\circ} \mathrm{F}-32\right) \times 5 / 9$ & 37.78 & degree C \\
\hline Insulation 1 thickness & 0.40 & $\mathrm{ft}$ & 0.3048 & 0.12 & \\
\hline Thermal conductivity of insulation 1 & 0.15 & Btu/hr.ft.F & 1.7307 & 0.26 & $\mathrm{~W} / \mathrm{mc}$ \\
\hline Insulation 2 thickness & 0.60 & $\mathrm{ft}$ & 0.3048 & 0.18 & $\mathrm{~m}$ \\
\hline Thermal conductivity of insulation 2 & 0.40 & Btu/hr.ft.F & 1.7307 & 0.69 & $\mathrm{~W} / \mathrm{mc}$ \\
\hline Thickness of pot material & 0.15 & $\mathrm{ft}$ & 0.3048 & 0.05 & $\mathrm{~m}$ \\
\hline Thermal conductivity of pot material & 20 & Btu/hr.ft.F & 1.7307 & 34.61 & $\mathrm{~W} / \mathrm{mC}$ \\
\hline Heat loss through the bottom of the Pot & 26,349 & Btu/hr & 0.29 & 7,723 & w \\
\hline \multicolumn{6}{|l|}{ 3. Heat loss through walls of the Pot } \\
\hline Total wall area & 336 & $\mathrm{ft} 2$ & 0.093 & 31.22 & $\mathrm{~m} 2$ \\
\hline Temperature of walls & 235 & degree $\mathrm{F}$ & $\left({ }^{\circ} \mathrm{F}-32\right) \times 5 / 9$ & 112.78 & degree C \\
\hline Heat convection coefficient & 1 & Btu/hr.ft2.F & 5.6786 & 5.68 & $\mathrm{~W} / \mathrm{m} 2 \mathrm{C}$ \\
\hline Convection heat loss & 53,760 & Btu/hr & .29 & 15,590 & w \\
\hline Emissivity & 0.6 & & & & \\
\hline Radiation heat loss & 52,228 & Btu/hr & .29 & 15,146 & W \\
\hline Heat loss through the walls of the Pot & 105,988 & Btu/hr & .29 & 30,736 & w \\
\hline
\end{tabular}

Figure 29: Pot Model worksheet screenshot (cont)

The heat loss through the bottom of the pot seems to be not significant $(\sim 0.03$ $\mathrm{MMbtu} / \mathrm{hr})$. But the heat loss through the walls has a significant value ( $\sim 0.1 \mathrm{MMBtu} / \mathrm{hr})$. 


\begin{tabular}{|c|c|c|c|c|c|}
\hline \multicolumn{6}{|l|}{ 4. Heat transferred from (to) the strip } \\
\hline Thickness of strip & 0.00208 & $\mathrm{ft}$ & 0.3048 & 0.00 & $\mathrm{~m}$ \\
\hline Width of strip & 4.3 & $\mathrm{ft}$ & 0.3048 & 1.31 & $\mathrm{~m}$ \\
\hline Density of strip & 490 & $\mathrm{Ib} / \mathrm{ft} 3$ & 16.02 & $7,849.80$ & $\mathrm{~kg} / \mathrm{m} 3$ \\
\hline Line speed & 423 & $\mathrm{ft} / \mathrm{min}$ & 0.3048 & 128.93 & $\mathrm{~m} / \mathrm{min}$ \\
\hline Strip temperature at entry & 863 & degree $F$ & $\left({ }^{0} \mathrm{~F}-32\right) \times 5 / 9$ & 461.67 & degree $\mathrm{C}$ \\
\hline Strip temperature at exit & 870 & degree $\mathrm{F}$ & $\left({ }^{\circ} \mathrm{F}-32\right) \times 5 / 9$ & 465.56 & degree $C$ \\
\hline Heat transferred from (to) the strip & 120,149 & Btu/hr & .29 & 34,843 & w \\
\hline \multicolumn{6}{|l|}{ 5. Heat required to melt ingots and } \\
\hline \multicolumn{6}{|l|}{ maintain pot temperature } \\
\hline Amount of pure $\mathrm{Zn}$ ingot added & 3294 & $\mathrm{lbs} / \mathrm{hr}$ & 0.4535 & 1493.83 & $\mathrm{~kg} / \mathrm{hr}$ \\
\hline Amount of $\mathrm{Al}$ in $\mathrm{Al}-\mathrm{Zn}$ alloy ingot added & 9 & $\mathrm{lbs} / \mathrm{hr}$ & 0.4535 & 4.08 & $\mathrm{~kg} / \mathrm{hr}$ \\
\hline Amount of $\mathrm{Zn}$ in Al- $\mathrm{Zn}$ alloy ingot added & 81 & $\mathrm{lbs} / \mathrm{hr}$ & 0.4535 & 36.73 & $\mathrm{~kg} / \mathrm{hr}$ \\
\hline Heat required to melt ingots & 440,657 & Btu/hr & .29 & 127,790 & w \\
\hline \multicolumn{6}{|l|}{ 6. Heat loss due to air knife cooling effect } \\
\hline Heat convection coefficient & 9.7 & Btu/hr.ft2.F & 5.6786 & 55.00 & $\mathrm{~W} / \mathrm{m}$.degree $\mathrm{C}$ \\
\hline Air knife height & 2.5 & $\mathrm{ft}$ & 0.3048 & 0.91 & $\mathrm{~m}$ \\
\hline Cooling length & 1.6 & $\mathrm{ft}$ & 0.3048 & 0.49 & $\mathrm{~m}$ \\
\hline Strip width & 4.3 & $\mathrm{ft}$ & 0.3048 & 1.31 & $\mathrm{~m}$ \\
\hline \begin{tabular}{|l|} 
Wiping gas temperature \\
\end{tabular} & 157 & degree $\mathrm{F}$ & $\left({ }^{\circ} \mathrm{F}-32\right) \times 5 / 9$ & 69.44 & degree $\mathrm{C}$ \\
\hline Pot surface temperature & 820 & degree $\mathrm{F}$ & $\left({ }^{\circ} \mathrm{F}-32\right) \times 5 / 9$ & 437.78 & degree $\mathrm{C}$ \\
\hline a. Heat loss from the steel strip & 138,062 & Btu/hr & & & \\
\hline b. Heat loss from the pot & 88,360 & Btu/hr & & & \\
\hline Total air knife heat loss & 226,422 & Btu/hr & 0.29 & 65,662 & w \\
\hline
\end{tabular}

Figure 30: Pot Model worksheet screenshot (cont)

Heat absorption from the steel strip after coming through the pot is also significant ( $0.12 \mathrm{MMBtu} / \mathrm{hr}$ ). Air knife shows to have a significant impact on the total heat loss by its cooling effect $(\sim 0.2 \mathrm{MMBtu} / \mathrm{hr})$. Heat required to melt ingots and maintain pot temperature seems to be the biggest heat loss so far $(\sim 0.6 \mathrm{MMBtu} / \mathrm{hr})$.

\begin{tabular}{|c|c|c|c|c|c|}
\hline 7. Zinc coating heat loss & & & & & \\
\hline Coating weight & 0.6 & $\mathrm{oz} / \mathrm{ft} 2$ & 305.15 & 183.09 & $\mathrm{~g} / \mathrm{m} 2$ \\
\hline Line speed & 423 & $\mathrm{ft} / \mathrm{min}$ & 0.3048 & 128.93 & $\mathrm{~m} / \mathrm{min}$ \\
\hline Strip width & 4.3 & $\mathrm{ft}$ & 0.3048 & 1.31 & $\mathrm{~m}$ \\
\hline Heat loss from zinc coating & 529,536 & Btu/hr & 0.29 & 153,565 & w \\
\hline \multicolumn{6}{|l|}{ 8. Dross removal heat loss } \\
\hline Total amount of dross & 300 & $\mathrm{lbs} / \mathrm{hr}$ & 0.4535 & 136.05 & $\mathrm{~kg} / \mathrm{hr}$ \\
\hline Average temperature of the dross & 860 & degree $\mathrm{F}$ & $\left({ }^{\circ} \mathrm{F}-32\right) \times 5 / 9$ & 460.00 & degree C \\
\hline Percentage of $\mathrm{Al}$ in dross & 3 & $\%$ & & 3 & $\%$ \\
\hline Percentage of $\mathrm{Fe}$ in dross & 2 & $\%$ & & 2 & $\%$ \\
\hline Percentage of $\mathrm{Zn}$ in dross & 94 & $\%$ & & 94 & $\%$ \\
\hline Percentage of $\mathrm{Al} 2 \mathrm{O} 3$ in dross & 1 & $\%$ & & 1 & $\%$ \\
\hline Heat loss from dross removal & 45,831 & Btu/hr & 0.29 & 13,291 & w \\
\hline \multicolumn{6}{|l|}{ 9. Heat loss due to excessive zinc } \\
\hline Amount of excessive zinc & 1,000 & $\mathrm{lbs} / \mathrm{hr}$ & 0.4535 & 453.5 & $\mathrm{~kg} / \mathrm{hr}$ \\
\hline Temperature of excessive zinc & 700 & degree $\mathrm{F}$ & $\left({ }^{\circ} \mathrm{F}-32\right) \times 5 / 9$ & 371.11 & degree C \\
\hline Heat loss due to excessive zinc & 19,541 & Btu/hr & 0.29 & 5,667 & W \\
\hline \multicolumn{6}{|l|}{ C. Summary } \\
\hline \multicolumn{6}{|l|}{ Total heat loss during production } \\
\hline Main Pot & 1.44 & MMBtu/hr & 290 & 416.78 & kW \\
\hline Premelt-pot & 0.44 & MMBtu/hr & 290 & 127.79 & kW \\
\hline Downtime (Main Pot) & 0.50 & MMBtu/hr & 290 & 143.76 & kW \\
\hline
\end{tabular}

Figure 31: Pot Model worksheet screenshot (cont)

Heat loss from zinc coating is the second largest heat loss (0.5 MMBtu/hr). Heat loss from dross removal seems to be not significant. 
After all heat losses have been calculated. A summary of total heat losses will present the total values in U.S and English units. A screenshot for the Summary worksheet is shown below.

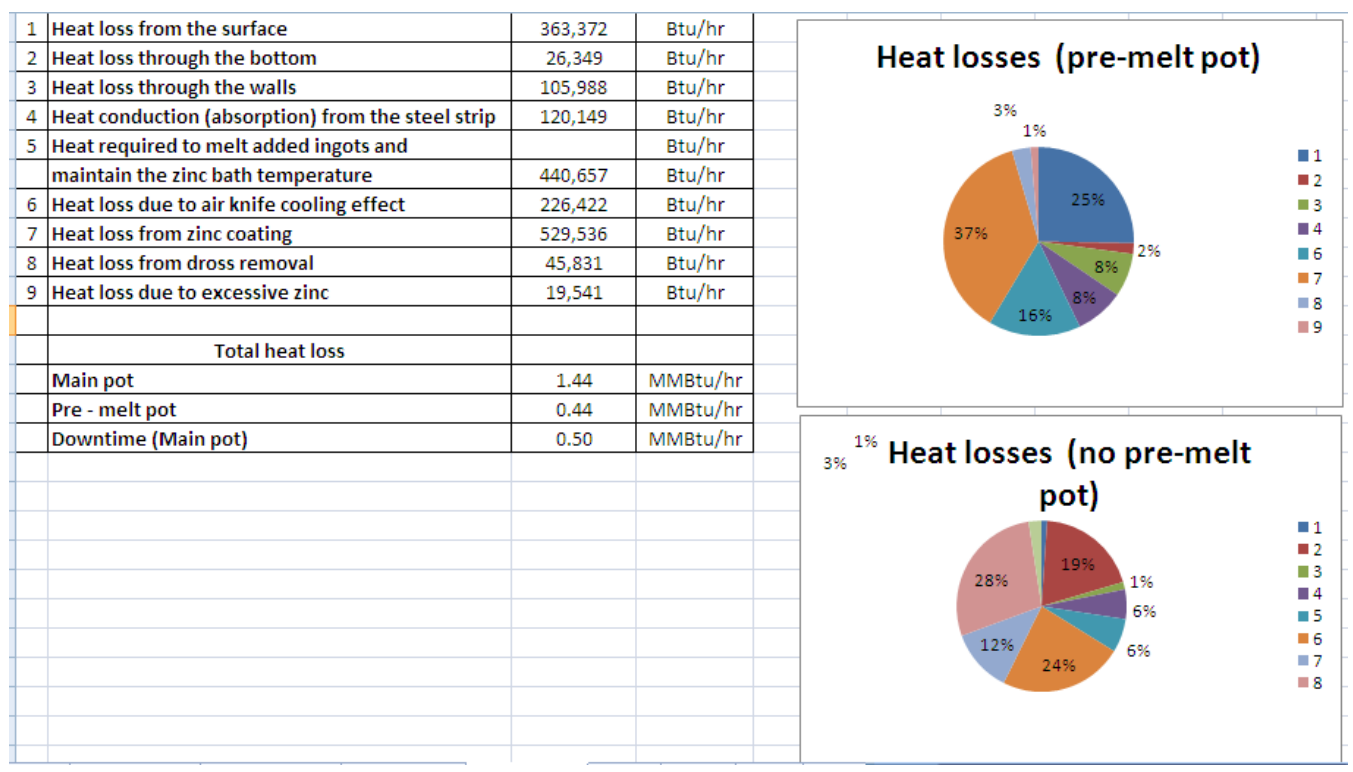

Figure 32: Summary worksheet screenshot

Screen shots for Ingot, Dross, Background, Zinc coating, Strip and Reference are shown in Appendix D.

Below is the screenshot for the Heat balance worksheet. From the energy conservation law, energy coming out of the system should be equal to energy coming into the system in the state of equilibrium. Therefore, heat input should be equal to heat output for the main pot. Unaccounted heat is the heat loss that is unable to recognize or estimate correctly.

\begin{tabular}{|l|r|l|r|}
\hline \multicolumn{3}{|c|}{ Main pot (with a pre-melt pot) } \\
\hline \multicolumn{2}{|c|}{ IN (MMBTu/hr) } & \multicolumn{2}{c|}{ OUT (MMBtu/hr) } \\
\hline Strip & 11.56 & Strip & 11.68 \\
\hline Electrical & 1.00 & Coating heat loss & 0.53 \\
\hline Ingots & 0.57 & Dross & 0.05 \\
\hline & & Air knife & 0.23 \\
\hline & & Surface & 0.36 \\
\hline & & Walls & 0.11 \\
\hline & & Bottom & 0.03 \\
\hline & & Excessive zinc & 0.02 \\
\hline & & Unaccounted heat & 0.13 \\
\hline & $\mathbf{1 3 . 1 3}$ & & $\mathbf{1 3 . 1 3}$ \\
\hline & & & \\
\hline Load factor & $\mathbf{0 . 7 3}$ & & \\
\hline
\end{tabular}

\begin{tabular}{|l|r|l|r|}
\hline \multicolumn{3}{|c|}{ Main pot (with no pre-melt pot) } \\
\hline \multicolumn{1}{|c|}{ IN (MMBTu/hr) } & \multicolumn{2}{c|}{ OUT (MMBtu/hr) } \\
\hline Strip & 11.56 & Strip & 11.68 \\
\hline Electrical & 1.37 & Coating heat loss & 0.53 \\
\hline Ingots & 0.00 & Dross & 0.05 \\
\hline & & Air knife & 0.23 \\
\hline & & Surface & 0.36 \\
\hline & & Walls & 0.11 \\
\hline & & Bottom & 0.03 \\
\hline & & Excessive zinc & 0.02 \\
\hline & & Unaccounted heat & -0.07 \\
\hline & 12.93 & & 12.93 \\
\hline & & & \\
\hline Load factor & 1.00 & & \\
\hline
\end{tabular}

Figure 33: Heat balance worksheet screenshot 


\begin{tabular}{|c|c|c|c|c|c|}
\hline \multicolumn{3}{|c|}{ IN (lbs/hr) } & \multicolumn{3}{c|}{ OUT (lbs/hr) } \\
\hline Strip & $\mathrm{Fe}$ & 111,229 & Strip & $\mathrm{Fe}$ & 111,223 \\
\hline & & & & & \\
\hline Ingots & & & Dross & & \\
\hline & Pure Zn & 3,294 & & $\mathrm{Al}$ & 9 \\
\hline & Al in Al-Zn & 9 & & $\mathrm{Fe}$ & 6 \\
\hline & Zn in Al-Zn & 81 & & $\mathrm{Zn}$ & 282 \\
\hline & & & & & \\
\hline Excessive zinc & $\mathrm{Zn}$ & 1,000 & Coating & $\mathrm{Zn}$ & 4,093 \\
\hline Total & & $\mathbf{1 1 5 , 6 1 3}$ & & & $\mathbf{1 1 5 , 6 1 3}$ \\
\hline
\end{tabular}

Figure 34: Mass balance

In the case of having a pre-melt pot, heat supply from the electrical source shows a lower value (1 MMBtu/hr compared to $1.37 \mathrm{MMBtu} / \mathrm{hr}$ ). In the case of not having a pre-melt pot, electrical source needs to operate at $100 \%$ load to compensate for the heat loss to melt the ingots and maintain the pot temperature.

Below is the graph showing the percentage of total heat losses for every heat loss in the main pot when there is a pre-melt pot.

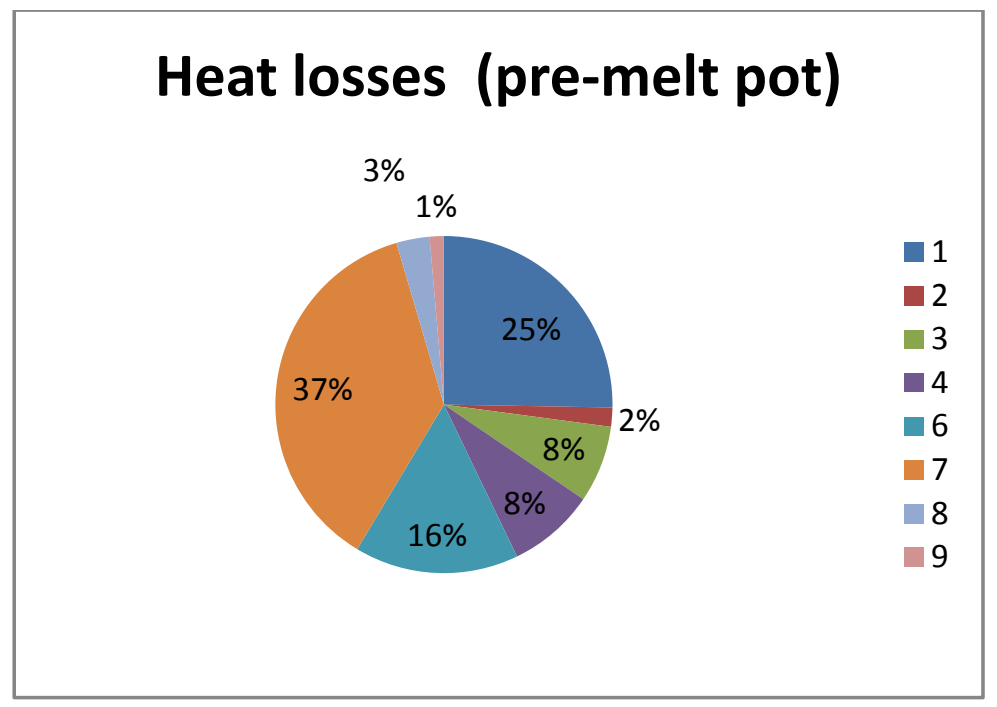

Figure 35: Heat losses’ percentages when there is a pre-melt pot

Because the largest heat loss which is the heat required to melt ingots was incurred in the pre-melt pot. Largest heat loss in the main pot now is the heat loss from the zinc coating. A large portion of hot zinc is coming along with the strip out of the pot. This portion of hot zinc carries heat away from the pot, therefore it is considered as a heat loss to the system. The second largest heat loss is the heat loss from the surface of the pot. This heat loss includes heat convection and radiation from the hot metals on the surface. This heat loss mainly depends on the emissivity and temperature of the materials floating on the 
surface. The fourth largest heat loss is the heat loss due to the air knife cooling effect. The air flow from the air knives cools down the hot liquid zinc in the process of solidification of the zinc coating as well as the surface of the pot as the air flow comes along the steel strip back to the pot surface. Heat losses to steel strip and from the walls seem to be significant (both are higher than 0.1 MMBtu/hr). Heat losses from the bottom and from dross removal are least significant (both are less than $0.1 \mathrm{MMBtu} / \mathrm{hr}$ ).

Below is the graph showing the percentage of total heat losses for every heat loss in the main pot when there is no pre-melt pot.

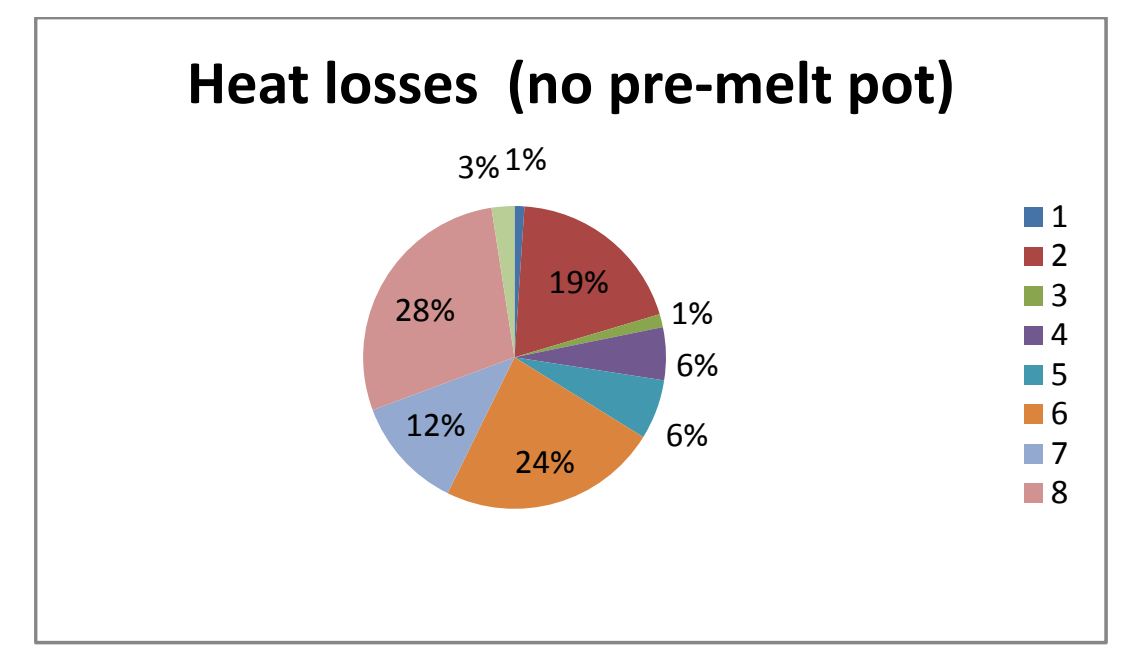

Figure 36: Heat losses' percentages when there is no pre-melt pot

As we can see from the graph, the largest heat loss is the heat required to melt ingots and maintain pot temperature. In the case of no pre-melt pot existing in the process, ingots are put into the main pot every period of time. The order from the second largest to the smallest heat loss is still the same as in the case of having a pre-melt pot.

\subsection{Sensitivity analysis}

Sensitivity analysis has been performed in chapter 4. From the sensitivity analysis, sensitivity factor can be calculated to see how sensitive total heat loss can be to one product or process parameter.

+ Length of the pot: changes from 13 to $10 \mathrm{ft}$, total heat loss changes from 1.44MMBtu/hr to $1.33 \mathrm{MMBtu} / \mathrm{hr}$. 
Sensitivity factor $=\frac{1.33-1.44}{10-13}=0.03$

When the length of the pot increases by $1 \mathrm{ft}$, total heat loss will increase by 0.03 $\mathrm{MMBtu} / \mathrm{hr}$.

+ Width of the pot: changes from 11 to $9 \mathrm{ft}$, total heat loss changes from $1.44 \mathrm{MMBtu} / \mathrm{hr}$ to $1.36 \mathrm{MMBtu} / \mathrm{hr}$.

Sensitivity factor $=\frac{1.36-1.44}{9-11}=0.04$

When the width of the pot increases by $1 \mathrm{ft}$, total heat loss will increase by 0.04 $\mathrm{MMBtu} / \mathrm{hr}$.

+ Pot temperature: changes from 870 to $850^{\circ} \mathrm{F}$, total heat loss changes from 1.44MMBtu/hr to $1.08 \mathrm{MMBtu} / \mathrm{hr}$.

Sensitivity factor $=\frac{1.08-1.44}{850-870}=0.02$

When the pot temperature increases by $1^{0} \mathrm{~F}$, total heat loss will increase by 0.02 MMBtu/hr.

+ Ambient temperature: changes from 75 to $90^{\circ} \mathrm{F}$, total heat loss changes from 1.39MMBtu/hr to $1.38 \mathrm{MMBtu} / \mathrm{hr}$.

Sensitivity factor $=\frac{1.38-1.39}{90-75}=-0.0067$

When the ambient temperature increases by $1^{0} \mathrm{~F}$, total heat loss will decrease by 0.0067 $\mathrm{MMBtu} / \mathrm{hr}$.

+ Emissivity: changes from 0.3 to 0.4 , total heat loss changes from $1.44 \mathrm{MMBtu} / \mathrm{hr}$ to 1.50 MMBtu/hr.

Sensitivity factor $=\frac{1.50-1.44}{0.4-0.3}=0.6$

When the emissivity of the materials on the pot surface increases by 0.1 , total heat loss will decrease by $0.06 \mathrm{MMBtu} / \mathrm{hr}$

+ Thermal conductivity:

Sensitivity factor $\approx 0$ 
Total heat loss change very little with the change of thermal conductivity of the materials of the pot and insulations

+ Strip entry temperature: changes from 863 to $860^{\circ} \mathrm{F}$, total heat loss changes from 1.44MMBtu/hr to $1.49 \mathrm{MMBtu} / \mathrm{hr}$.

Sensitivity factor $=\frac{1.49-1.44}{860-863}=0.02$

When the strip entry temperature increases by $1^{0} \mathrm{~F}$, total heat loss will decrease by 0.02 MMBtu/hr.

+ Cooling length: changes from 1.6 to $2 \mathrm{ft}$, total heat loss changes from 1.44MMBtu/hr to $1.46 \mathrm{MMBtu} / \mathrm{hr}$.

Sensitivity factor $=\frac{1.46-1.44}{2-1.6}=0.05$

When the cooling length increases by $1 \mathrm{ft}$, total heat loss will increase by 0.05 MMBtu/hr.

+ Wiping gas temperature: changes from 157 to $140^{\circ} \mathrm{F}$, total heat loss changes from 1.44 MMBtu/hr to $1.44 \mathrm{MMBtu} / \mathrm{hr}$.

Sensitivity factor $=\frac{1.44-1.44}{140-157}=0$

When the wiping gas temperature increases by $1^{0} \mathrm{~F}$, total heat loss will decrease by 0 MMBtu/hr.

\subsection{Conclusion}

The model was applied using a set of data for input parameters from the host company. The model was run and results were obtained and discussed. In the case of having a premelt pot, heat supply from the electrical source shows a lower value (1 MMBtu/hr compared to $1.37 \mathrm{MMBtu} / \mathrm{hr}$ ). In the case of not having a pre-melt pot, electrical source needs to operate at $100 \%$ load to compensate for the heat loss to melt the ingots and maintain the pot temperature. When there is no pre-melt pot, the largest heat loss is the heat required to melt ingots and maintain pot temperature. When there is a pre-melt pot in the process, the largest heat loss in the main pot is the heat loss from zinc coating. Heat 
losses from the surface, walls, air knife cooling effect, and steel strip are significant. Heat losses from the bottom and dross removal seem not to be significant.

Emissivity, dimensions of the pot, temperature of the pot, and strip entry temperature have significant impact on the total heat loss. Total heat loss is most sensitive to changes of one of these parameters.

Ambient temperature, thermal conductivity and wiping gas temperature do not have very much significant impact on the total heat loss. Total heat loss is not really sensitive to changes of one of these parameters.

\subsection{SSAB}

Input parameters were obtained during the plant visit to SSAB plant in Sweden. These data were input into the program and the results are shown below.

\begin{tabular}{|l|c|c|c|c|c|}
\hline Product and Process parameters & \multicolumn{2}{|c|}{ US units } & $\begin{array}{c}\text { Multiplicative } \\
\text { conversion } \\
\text { factor }\end{array}$ & \multicolumn{2}{c|}{ Metric units } \\
\hline Pot length & 14.56 & $\mathrm{ft}$ & 0.3048 & 4.44 & $\mathrm{~m}$ \\
\hline Pot width & 7 & $\mathrm{ft}$ & 0.3048 & 2.13 & $\mathrm{~m}$ \\
\hline Pot height & 10 & $\mathrm{ft}$ & 0.3048 & 3.05 & $\mathrm{~m}$ \\
\hline Pot temperature & 874 & degree $\mathrm{F}$ & $\left({ }^{\circ} \mathrm{F}-32\right) \times 5 / 9$ & 467.78 & degree C \\
\hline Pot surface temperature & 800.6 & degree $\mathrm{F}$ & $\left({ }^{\circ} \mathrm{F}-32\right) \times 5 / 9$ & 427.00 & degree C \\
\hline Ambient temperature & 95 & degree $\mathrm{F}$ & $\left({ }^{\circ} \mathrm{F}-32\right) \times 5 / 9$ & 35.00 & degree C \\
\hline Line speed & 410.1 & $\mathrm{ft} / \mathrm{min}$ & 0.3048 & 125.00 & $\mathrm{~m} / \mathrm{min}$ \\
\hline Coating weight & 0.90 & $0 z / \mathrm{ft} 2$ & 305.15 & 275. & $\mathrm{~g} / \mathrm{m} 2$ \\
\hline Strip width & 4.01 & $\mathrm{ft}$ & 0.3048 & 1.22 & $\mathrm{~m}$ \\
\hline Strip thickness & 0.0015 & $\mathrm{ft}$ & 0.3048 & 0.00 & $\mathrm{~m}$ \\
\hline
\end{tabular}

Figure 37: Product and process parameters

Figure 37 shows the product and process parameters which include the pot dimensions, temperatures, line speed, strip thickness and width, etc. 


\begin{tabular}{|c|c|c|c|c|c|}
\hline 1. Heat loss from surface of the Pot & & & & & \\
\hline Emissivity & 0.3 & & & & \\
\hline Stephen Boltzmann & $1.71 \mathrm{E}-09$ & Btu/h. ft $^{2} .{ }^{\circ} \mathrm{R}^{4}$ & & 5.67E-08 & $\mathrm{W} / \mathrm{m} 2 .^{\circ} \mathrm{K} 4$ \\
\hline Radiation heat loss (surface) & 127,244 & Btu/hr & .29 & 37,295 & w \\
\hline Convection heat loss (surface) & 114,148 & Btu/hr & .29 & 33,103 & w \\
\hline Heat loss from surface of the Pot & 241,392 & Btu/hr & .29 & 70,004 & w \\
\hline \multicolumn{6}{|l|}{ 2. Heat loss through the bottom of the Pot } \\
\hline Area of bottom & 101.92 & $\mathrm{ft} 2$ & 0.093 & 9.47 & $\mathrm{~m} 2$ \\
\hline Temperature of pot & 874 & degree $\mathrm{F}$ & $\left({ }^{\circ} \mathrm{F}-32\right) \times 5 / 9$ & 467.78 & degree $\mathrm{C}$ \\
\hline Temperature of bottom of the pot & 149 & degree $\mathrm{F}$ & $\left({ }^{\circ} \mathrm{F}-32\right) \times 5 / 9$ & 65.00 & degree $\mathrm{C}$ \\
\hline \begin{tabular}{|l|} 
Insulation 1 thickness \\
\end{tabular} & 1.04 & $\mathrm{ft}$ & \begin{tabular}{|l|l}
0.3048 \\
\end{tabular} & 0.32 & \\
\hline Thermal conductivity of insulation 1 & 9.00 & Btu/hr.ft.F & 1.7307 & 15.58 & $\mathrm{~W} / \mathrm{m}^{\circ} \mathrm{C}$ \\
\hline Insulation 2 thickness & 2.00 & $\mathrm{ft}$ & 0.3048 & 0.61 & $\mathrm{~m}$ \\
\hline Thermal conductivity of insulation 2 & 10.00 & Btu/hr.ft.F & 1.7307 & 17.31 & $\mathrm{~W} / \mathrm{m}^{\circ} \mathrm{C}$ \\
\hline Thickness of pot material & 0.15 & $\mathrm{ft}$ & 0.3048 & 0.05 & $\mathrm{~m}$ \\
\hline Thermal conductivity of pot material & 20 & Btu/hr.ft.F & 1.7307 & 34.61 & $\mathrm{~W} / \mathrm{m}^{\circ} \mathrm{C}$ \\
\hline Heat loss through the bottom of the Pot & 228,728 & Btu/hr & 0.29 & 67,040 & W \\
\hline \multicolumn{6}{|l|}{ 3. Heat loss through walls of the Pot } \\
\hline Total wall area & 431.2 & $\mathrm{ft} 2$ & 0.093 & 40.06 & $\mathrm{~m} 2$ \\
\hline Temperature of walls & 149 & degree $F$ & $\left({ }^{\circ} \mathrm{F}-32\right) \times 5 / 9$ & 65.00 & degree $\mathrm{C}$ \\
\hline Heat convection coefficient & 1 & Btu/hr.ft2.F & 5.6786 & 5.68 & $\mathrm{~W} / \mathrm{m} 2 \mathrm{C}$ \\
\hline Convection heat loss & 23,285 & Btu/hr & .29 & 6,753 & W \\
\hline Emissivity & 0.6 & & & & \\
\hline Radiation heat loss & 18,891 & Btu/hr & .29 & 5,478 & W \\
\hline Heat loss through the walls of the Pot & 42,176 & Btu/hr & .29 & 12,231 & w \\
\hline
\end{tabular}

Figure 38: Computation of the heat losses

The program automatically computes the heat losses based on the input given and the output is shown in shaded cells. For SSAB, heat loss through the bottom is relatively high compared to other companies. This may be due to high conductivities of the insulating materials installed at the bottom of the pot.

\begin{tabular}{|c|c|c|c|c|c|}
\hline \multicolumn{6}{|l|}{ 4. Heat transferred from (to) the strip } \\
\hline Thickness of strip & 0.0015 & $\mathrm{ft}$ & 0.3048 & 0.00 & $\mathrm{~m}$ \\
\hline Width of strip & 4.01 & $\mathrm{ft}$ & 0.3048 & 1.22 & $m$ \\
\hline Density of strip & 490 & $\mathrm{lb} / \mathrm{ft} 3$ & 16.02 & $7,849.80$ & $\mathrm{~kg} / \mathrm{m} 3$ \\
\hline Line speed & 410.1 & $\mathrm{ft} / \mathrm{min}$ & 0.3048 & 125.00 & $\mathrm{~m} / \mathrm{min}$ \\
\hline Strip temperature at entry & 856.4 & degree $\mathrm{F}$ & $\left({ }^{\circ} \mathrm{F}-32\right) \times 5 / 9$ & 458.00 & degree $\mathrm{C}$ \\
\hline Strip temperature at exit & 865.4 & degree $\mathrm{F}$ & $\left({ }^{\circ} \mathrm{F}-32\right) \times 5 / 9$ & 463.00 & degree $\mathrm{C}$ \\
\hline Heat transferred from (to) the strip & 100,462 & $\mathrm{Btu} / \mathrm{hr}$ & .29 & 29,134 & w \\
\hline \multicolumn{6}{|l|}{ 5. Heat required to melt ingots and } \\
\hline \multicolumn{6}{|l|}{ maintain pot temperature } \\
\hline Amount of pure $\mathrm{Zn}$ ingot added & 3411 & $\mathrm{lbs} / \mathrm{hr}$ & 0.4535 & 1546.89 & $\mathrm{~kg} / \mathrm{hr}$ \\
\hline Amount of $\mathrm{Al}$ in $\mathrm{Al}-\mathrm{Zn}$ alloy ingot added & 52 & $\mathrm{lbs} / \mathrm{hr}$ & 0.4535 & 23.58 & $\mathrm{~kg} / \mathrm{hr}$ \\
\hline Amount of $\mathrm{Zn}$ in Al-Zn alloy ingot added & 468 & $\mathrm{lbs} / \mathrm{hr}$ & 0.4535 & 212.24 & $\mathrm{~kg} / \mathrm{hr}$ \\
\hline Heat required to melt ingots & 516,187 & Btu/hr & .29 & 149,694 & w \\
\hline \multicolumn{6}{|l|}{ 6. Heat loss due to air knife cooling effect } \\
\hline Heat convection coefficient & 9.7 & Btu/hr.ft2.F & 5.6786 & 55.00 & $\mathrm{w} / \mathrm{m}^{\circ} \mathrm{C}$ \\
\hline Air knife height & 0.755 & $\mathrm{ft}$ & 0.3048 & 0.91 & $m$ \\
\hline Cooling length & 2.5 & $\mathrm{ft}$ & 0.3048 & 0.76 & $m$ \\
\hline Strip width & 4.01 & $\mathrm{ft}$ & 0.3048 & 1.22 & $\mathrm{~m}$ \\
\hline Wiping gas temperature & 157 & degree $\mathrm{F}$ & $\left({ }^{\circ} \mathrm{F}-32\right) \times 5 / 9$ & 69.44 & degree $\mathrm{C}$ \\
\hline Pot surface temperature & 800.6 & degree $\mathrm{F}$ & $\left({ }^{\circ} \mathrm{F}-32\right) \times 5 / 9$ & 427.00 & degree $\mathrm{C}$ \\
\hline a. Heat loss from the steel strip & 37,745 & Btu/hr & & & \\
\hline b. Heat loss from the pot & 124,983 & Btu/hr & & & \\
\hline Total air knife heat loss & 162,728 & Btu/hr & 0.29 & 47,191 & $w$ \\
\hline
\end{tabular}

Figure 39: Computation of the heat losses (cont)

It can be seen that the heat required to melt ingots and maintain pot temperature is the largest heat loss among all heat losses. 


\begin{tabular}{|c|c|c|c|c|c|}
\hline 7. Zinc coating heat loss & & & & & \\
\hline Coating weight & 0.6 & $\mathrm{oz} / \mathrm{ft} 2$ & 305.15 & 183.09 & $\mathrm{~g} / \mathrm{m} 2$ \\
\hline Line speed & 410.1 & $\mathrm{ft} / \mathrm{min}$ & 0.3048 & 125. & $\mathrm{~m} / \mathrm{min}$ \\
\hline Strip width & 4.01 & $\mathrm{ft}$ & 0.3048 & 1.22 & $\mathrm{~m}$ \\
\hline Heat loss from zinc coating & 480,464 & Btu/hr & 0.29 & 139,335 & w \\
\hline \multicolumn{6}{|l|}{ 8. Dross removal heat loss } \\
\hline Total amount of dross & 300 & $\mathrm{lbs} / \mathrm{hr}$ & 0.4535 & 136.05 & $\mathrm{~kg} / \mathrm{hr}$ \\
\hline Average temperature of the dross & 860 & degree $\mathrm{F}$ & $\left({ }^{\circ} \mathrm{F}-32\right) \times 5 / 9$ & 460.00 & degree $\mathrm{C}$ \\
\hline Percentage of $\mathrm{Al}$ in dross & 3 & $\%$ & & 3 & $\%$ \\
\hline Percentage of Fe in dross & 2 & $\%$ & & 2 & $\%$ \\
\hline Percentage of $\mathrm{Zn}$ in dross & 94 & $\%$ & & 94 & $\%$ \\
\hline Percentage of $\mathrm{Al} 2 \mathrm{O} 3$ in dross & 1 & $\%$ & & 1 & $\%$ \\
\hline Heat loss from dross removal & 45,831 & Btu/hr & 0.29 & 13,291 & w \\
\hline \multicolumn{6}{|l|}{ 9. Heat loss due to excessive zinc } \\
\hline Amount of excessive zinc & 1,000 & $\mathrm{lbs} / \mathrm{hr}$ & 0.4535 & 453.5 & $\mathrm{~kg} / \mathrm{hr}$ \\
\hline Temperature of excessive zinc & 700 & degree $\mathrm{F}$ & $\left({ }^{\circ} \mathrm{F}-32\right) \times 5 / 9$ & 371.11 & degree $\mathrm{C}$ \\
\hline Heat loss due to excessive zinc & 20,001 & Btu/hr & 0.29 & 5,800 & W \\
\hline \multicolumn{6}{|l|}{ C. Summary } \\
\hline \multicolumn{6}{|l|}{ Total heat loss during production } \\
\hline Main Pot & 1.32 & MMBtu/hr & 290 & 383.32 & kW \\
\hline Premelt-pot & 0.52 & MMBtu/hr & 290 & 149.69 & $\mathrm{~kW}$ \\
\hline Downtime (Main Pot) & 0.51 & MMBtu/hr & 290 & 148.57 & kW \\
\hline
\end{tabular}

\section{Figure 40: Computation of the heat losses and Summary}

Heat loss from zinc coating is the second largest heat loss which contributes nearly one third of total heat loss in the main pot. Heat is being carried away with the liquid zinc coated on the steel strip surface.

\begin{tabular}{|c|c|c|c|c|c|}
\hline 1 & Heat loss from the surface & 241,392 & Btu/hr & \multirow{2}{*}{\multicolumn{2}{|c|}{ Heat losses (pre-melt pot) }} \\
\hline 2 & Heat loss through the bottom & 228,728 & Btu/hr & & \\
\hline 3 & Heat loss through the walls & 42,176 & Btu/hr & \multirow{12}{*}{$36 \%$} & \\
\hline 4 & Heat conduction (absorption) from the steel strip & 100,462 & $\mathrm{Btu} / \mathrm{hr}$ & & \\
\hline \multirow[t]{2}{*}{5} & Heat required to melt added ingots and & & Btu/hr & & $\mathbf{m}$ \\
\hline & maintain the zinc bath temperature & 516,187 & Btu/hr & & 2 \\
\hline 6 & Heat loss due to air knife cooling effect & 162,728 & Btu/hr & & $=3$ \\
\hline 7 & Heat loss from zinc coating & 480,464 & Btu/hr & & $=4$ \\
\hline 8 & Heat loss from dross removal & 45,831 & Btu/hr & & $=6$ \\
\hline \multirow[t]{15}{*}{9} & Heat loss due to excessive zinc & 20,001 & Btu/hr & & $=7$ \\
\hline & & & & & 9 \\
\hline & Total heat loss & & & & \\
\hline & Main pot & 1.32 & MMBtu/hr & & \\
\hline & Pre-melt pot & 0.52 & MMBtu/hr & & \\
\hline & Downtime (Main pot) & 0.51 & $\mathrm{MMBtu} / \mathrm{hr}$ & \multirow{3}{*}{\multicolumn{2}{|c|}{ Heat losses (no pre-melt pot) }} \\
\hline & & & & & \\
\hline & & & & & \\
\hline & & & & \multirow{7}{*}{$26 \%$} & $=1$ \\
\hline & & & & & $\begin{array}{l}\mathbf{m} \\
\mathbf{n}\end{array}$ \\
\hline & & & & & $\square 4$ \\
\hline & & & & & \pm 5 \\
\hline & & & & & 16 \\
\hline & & & & & 8 \\
\hline & & & & & 9 \\
\hline
\end{tabular}

Figure 41: Summary of heat losses and total heat loss

Figure 41 shows the summary of all heat losses taking place in the system. The pie charts show the percentage of contribution of each and every heat loss to the total heat loss. 


\begin{tabular}{|l|r|l|r|}
\hline \multicolumn{3}{|c|}{ Main pot (with a pre-melt pot) } \\
\hline \multicolumn{1}{|c|}{ IN (MMBTu/hr) } & \multicolumn{2}{c|}{ OUT (MMBtu/hr) } \\
\hline Strip & 7.46 & Strip & 7.56 \\
\hline Electrical & 1.00 & Coating heat loss & 0.48 \\
\hline Ingots & 0.52 & Dross & 0.05 \\
\hline & & Air knife & 0.16 \\
\hline & & Surface & 0.24 \\
\hline & & Walls & 0.04 \\
\hline & & Bottom & 0.23 \\
\hline & & Excessive zinc & 0.02 \\
\hline & & Unaccounted heat & 0.20 \\
\hline & 8.98 & & 8.98 \\
\hline & & & \\
\hline Load factor & $\mathbf{0 . 7 3}$ & & \\
\hline
\end{tabular}

\begin{tabular}{|l|r|l|r|}
\hline \multicolumn{3}{|c|}{ Main pot (with no pre-melt pot) } \\
\hline \multicolumn{2}{|c|}{ IN (MMBTu/hr) } & \multicolumn{2}{c|}{ OUT (MMBtu/hr) } \\
\hline Strip & 7.46 & Strip & 7.56 \\
\hline Electrical & 1.37 & Coating heat loss & 0.48 \\
\hline Ingots & 0.01 & Dross & 0.05 \\
\hline & & Air knife & 0.16 \\
\hline & & Surface & 0.24 \\
\hline & & Walls & 0.04 \\
\hline & & Bottom & 0.23 \\
\hline & & Excessive zinc & 0.02 \\
\hline & & Unaccounted heat & 0.05 \\
\hline & 8.84 & & 8.84 \\
\hline & & & \\
\hline Load factor & $\mathbf{1 . 0 0}$ & & \\
\hline
\end{tabular}

Figure 42: Heat balance for main pot

Figure 42 shows the heat balance in the main pot with two cases, one is with a pre-melt pot and one is without pre-melt pot. The heat balance shows amount of heat coming into the system and amount of heat coming out of the system in every aspect. 


\section{CHAPTER 6: CONCLUSION AND FUTURE WORK}

\subsection{Conclusion}

The model was applied using a set of data for input process and product parameters. These data are given for the production of an example product type. The model computed amount of heat losses that incurred in the pot.

From the results, it can be seen that the largest heat loss was the heat required to melt ingots, followed by the heat loss from zinc loss in the form of zinc coating. Heat losses from the surface and air knife cooling effect are also significant. The least significant heat losses were heat loss through the bottom and from the dross removal.

A heat balance was also generated in the model to balance the heat input and output of the system. Heat input is equal to the summation of heat supplied to the pot from steel strip and an electrical heat source. Heat output is equal to the summation of all the heat losses including the unaccounted heat loss that is unable to be measured.

From the results, sensitivity analyses were done to study the impact of changing parameters on the total heat losses. From the sensitivity analyses, it showed that total heat loss are most sensitive to the change of emissivities of the materials on the surface of the pot, pot temperature, dimensions of the pot, and strip entry temperature. Total heat losses are not really sensitive to the change of ambient temperature, thermal conductivity, and wiping gas temperature.

The model performed really well. It was able to produce reasonable results quickly. The quality of the results depends on the reliability of the input data as well as the understanding of galvanizing process and the program. Users should be trained on what data should be collected and how to run the program correctly before using it.

\subsection{Future work}

In the future, more plant visits will be made and more data will be collected. The model will be applied extensively to more galvanizing lines in order to help the galvanizers to have a more understanding about the energy consumption when producing their products. 
Training on how to use the program will be provided during the visits and also when it is requested by interested users.

The model can be improved by having better methods to calculate for some of the heat losses. For example, heat loss from the surface was calculated with the assumption that only one emissivity is applied to the materials on the surface and the temperature distribution is uniform. In reality, pot surface has a combination of metals, metal oxide, and metallic compounds floating on the surface. Their amount and composition are difficult to measure. Moreover, the temperature distribution of the pot surface is not uniform. An improved approach to determine the amount of this heat loss will be studied in the future. Other heat losses will also be examined to improve the accuracy of the model.

E-GEPDSS can be integrated with the GEPDSS to provide more thorough information about the energy consumption in a galvanizing line. Product and process parameters can be incorporated with system parameters to come up with a more rounded model which includes all the aspects of energy consumption. The integrated model will help the galvanizers to understand more about the costs in terms of energy and identify the potential for energy savings.

A more user-friendly program for the heat balance model can be introduced to help the users to use the model more easily and correctly. The program should also have a more user friendly interface and a better automatic computation built in. Visual Basic.Net is a good candidate of a programming language to build such a program. The program can also be a web-based program so that users can access it online and use it without having a need to install the program in their computers. 


\section{REFERENCES}

1. Kato, H., "Electrical Equipment for Continuous Strip Galvanizing Line", FUJI ELECTRIC REVIEW, 1969, Vol.15, No.5, pp. 159 - 163.

2. Ajersch, F., Ilinca, F., Hétu , and J.F., Goodwin , F.E., "Numerical Simulation of the Rate of Dross Formation In Continuous Galvanizing Baths", Canadian Metallurgical Quarterly, 2005, Vol.44, No.3, pp. 369-378.

3. Ajersch, F., Ilinca, F., and Hétu , J.F., "Simulation of Flow in a Continuous Galvanizing Bath: Part I. Thermal Effects of ingot Addition”, Met. and Mat. Trans. B, 2004, Vol. 35B, pp. 161-170.

4. Ajersch, F., Ilinca, F., and Hétu , J.F., "Simulation of Flow in a Continuous Galvanizing Bath: Part II. Transient Aluminum Distribution Resulting from Ingot Addition”, Met. and Mat. Trans. B, 2004, Vol. 35B, pp. 171-178.

5. Lee, S. J., Kim, S., Koh, M. S., and Choi, J. H., "Flow Field Analysis inside a Molten Zn Pot of the Continuous Hot-dip Galvanizing Process", ISIJ International, 2002, Vol. 42 , No. 4, pp. 407-413.

6. Bloch, G., Sirou, F., Eustache, V., and Fatrez, P., "Neural Intelligent Control for a Steel Plant”, Neural Networks, IEEE Transactions, 1997, Vol. 8, Issue 4, pp. 910 - 918.

7. Kim, Y. H., Cho, Y. W., Chung, S. H., Shim, J.D. and Ra, H. Y., "Numerical Analysis of Fluid Flow and Heat Transfer in Molten Zinc Pot of Continuous Hot-dip Galvanizing Line”, ISIJ International, 2000, Vol. 40, No. 7, pp. 706-712.

8. Ajersch, F., Ilinca, F., and Hétu, "Three-Dimensional Numerical Simulation of Turbulent Flow and Heat Transfer in a Continuous Galvanizing Bath", Num. Heat Transfer, Part A: Applications, 2003, Vol. 44, pp. 463-482.

9. Elsaadawy, E.A., Hanumanth, G.S., Balthazaar, A.K.S., Mcdermid, J.R., Hrymak , A.N., and Forbes, J.F., "Coating Weight Model for the Continuous Hot-Dip Galvanizing Process", Minerals, Metals \& Materials Society and ASM International, 2007.

10. Zhang, K., Tang, N.Y., Goodwin, F. E., Sexton, S., "Reaction of 316L Stainless Steel with a Galvanizing Bath", Journal of Material Science, 2007, Vol. 42, pp.9736-9745 
11. Shitov, A. V., Klimushkin, A. N., Stolyarskii, Agapeev, O. A., E. N., and Lobachev, P. V., "Recycling of the Dross Formed in Hot Galvanizing", Metallurgist, 2005, Vol. 49, Nos. 7-8.

12. Tang, N.Y., "Characteristics of Continuous Galvanizing Baths", Metallurgical and materials transactions B, 1999, Vol.30b, pp. 144-148.

13. Liu, X., Sikka, V. K., Bright, M., Sexton S., Barbero, E., and Hales, J. W. , "Development of a New Weld Overlay for Pot Hardware in Continuous Galvanizing lines", Galvatech, 2007.

14. Masui, T., Kaseda, Y., Isaka, K., "Basic Examination on Strip Wandering in Processing Plants”, ISIJ International, 2000, Vol. 40, No. 10, pp. 1019 -1023.

15. Corrosion Doctors, http://www.corrosion-doctors.org/MetalCoatings/Zinccoatings.htm, 1/12/2010.

16. GalvinfoNote 1.2, http://galvinfo.com/ginotes/GalvInfoNote_1_2.pdf, 1/12/2010.

17. http://www.ckit.co.za/secure/conveyor/troughed/corrosion-protection/steelprotection/steel-protection---06-galvanizing-of-sheet-metal.htm, 1/12/2010.

18. Bejan, A., "Heat Transfer", John Wiley \& Sons Inc, Canada, 1993.

19. GalvinfoNote 2.4.1, http://galvinfo.com/ginotes/GalvInfoNote_2_4_1.pdf, 1/14/2010.

20. Holman, J.P., "Heat Transfer", $9^{\text {th }}$ edition, McGraw-Hill, New York, 2002.

21. Laider, K.J., "The World of Physical Chemistry", Oxford University Press, 1993.

22. Perrot, P. , "A to Z of Thermodynamics", Oxford University Press, 1998.

23. Schuhmann, Jr. R., "Metallurgical Engineering”, Vol 1, Addison - Wesley Publishing Company, Inc., Massachusetts, 1952.

24. American Foundrymen's Society, “Cupola Handbook”, $5^{\text {th }}$ edition, Illinois, 1984. 


\section{APPENDIX}

\section{A. Air Properties:}

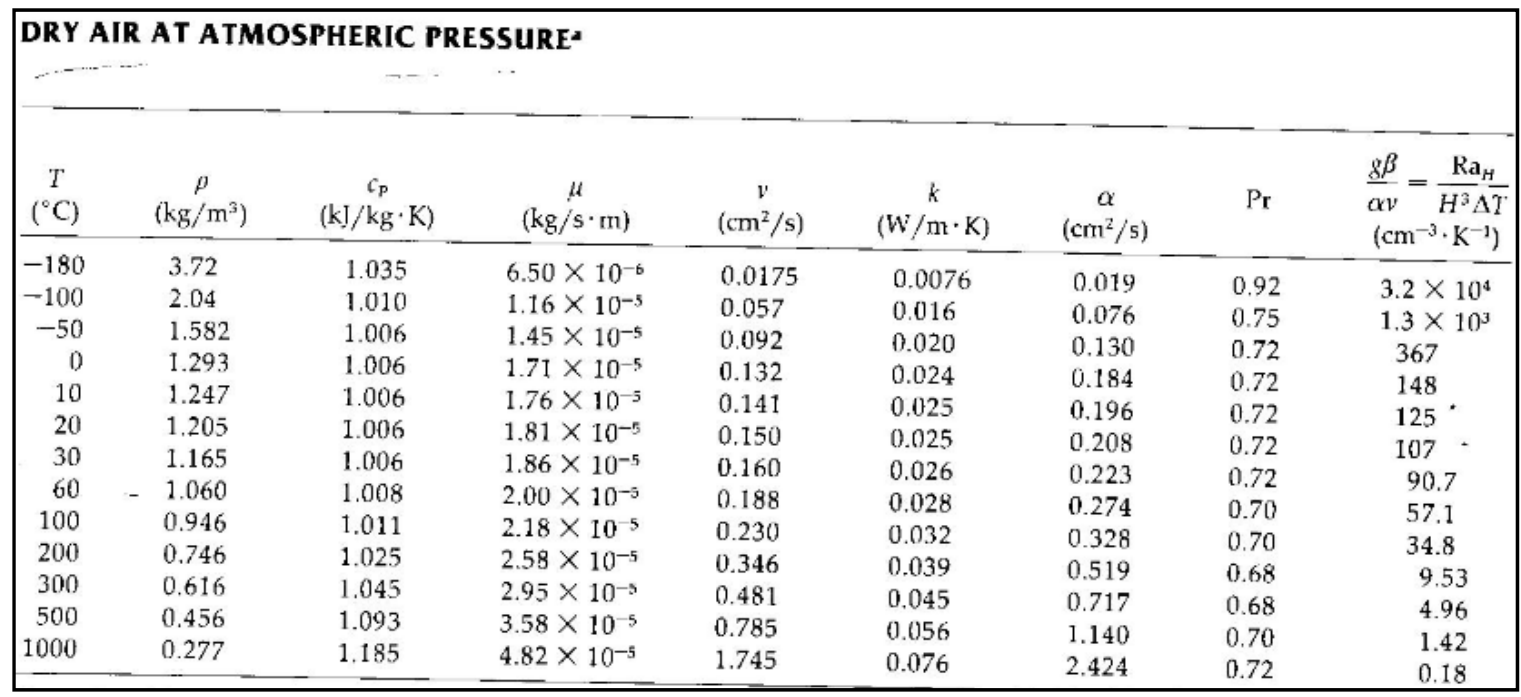

Figure 43: Dry air properties at atmospheric pressure [18]

\section{B. Air Knife Cooling Effect:}

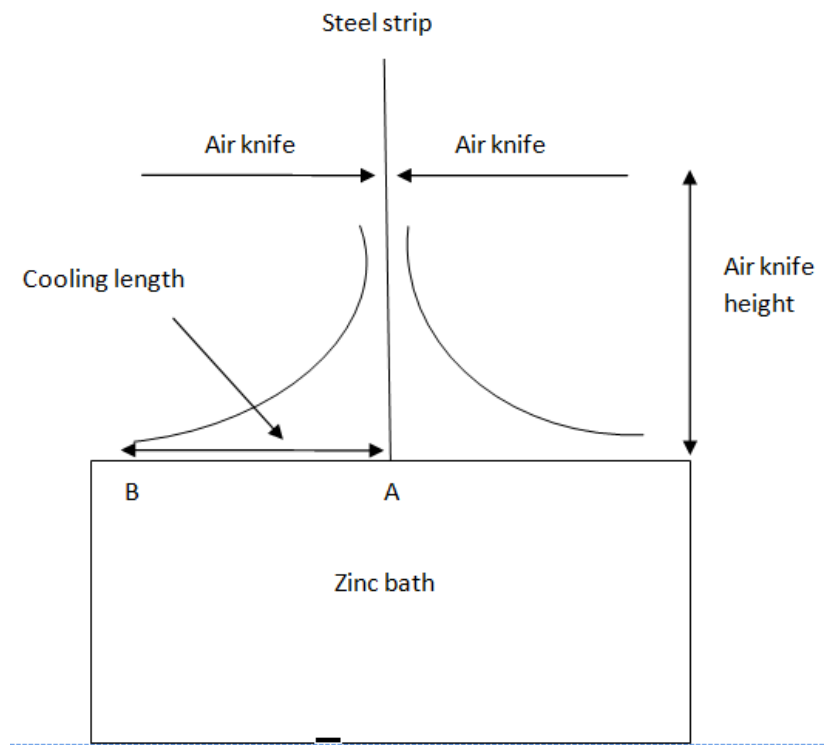

Figure 44: Air knife cooling effect 
As being described above, cooling length is the distance from point A where the steel strip is coming out of the pot to the extend (point B) where the air flow can reach over to the side wall of the pot surface.

\section{Heat Content for Metals}

Table 21: Coefficients for calculating heat contents of metals

\begin{tabular}{|c|c|c|c|c|c|}
\hline \multirow{2}{*}{} & \multicolumn{5}{|c|}{ Metals } \\
\cline { 2 - 6 } & $\mathrm{Fe}$ & \multicolumn{2}{|c|}{$\mathrm{Al}$} & \multicolumn{2}{c|}{ Zn } \\
\cline { 2 - 6 } & & \multicolumn{1}{|c}{$0-$} & & \multicolumn{2}{c|}{$0-$} \\
& $0-1033 \mathrm{~K}$ & $931.7 \mathrm{~K}$ & $>931.7 \mathrm{~K}$ & $692.7 \mathrm{~K}$ & $>692.7 \mathrm{~K}$ \\
\cline { 2 - 6 } & $\alpha$ & cryst & liq & cryst & liq \\
\hline $\mathrm{a}$ & 3.37 & 4.94 & 7 & 5.35 & 7.5 \\
\hline $\mathrm{b}$ & 0.00355 & 0.00148 & 0 & 0.0012 & 0 \\
\hline & - & & & & 0 \\
\hline $\mathrm{c}$ & 0.0000043 & 0 & 0 & 0 & -850 \\
\hline $\mathrm{d}$ & -1176 & -1605 & 330 & -1702 & \\
\hline
\end{tabular}

\section{Screenshots of the program}

A. Input parameters
\begin{tabular}{|l|c|c|c|c|c|}
\hline Product and Process parameters & \multicolumn{2}{|c|}{ US units } & \multicolumn{2}{|c|}{$\begin{array}{c}\text { Multiplicative } \\
\text { conversion factor }\end{array}$} & \multicolumn{2}{c|}{ Metric units } \\
\hline Pot length & & $\mathrm{ft}$ & 0.3048 & & $\mathrm{~m}$ \\
\hline Pot width & & $\mathrm{ft}$ & 0.3048 & & $\mathrm{~m}$ \\
\hline Pot height & & $\mathrm{ft}$ & 0.3048 & & $\mathrm{~m}$ \\
\hline Pot temperature & & degree $\mathrm{F}$ & $\left.{ }^{\circ} \mathrm{F}-32\right) \times 5 / 9$ & & degree C \\
\hline Pot surface temperature & & degree $\mathrm{F}$ & $\left({ }^{\circ} \mathrm{F}-32\right) \times 5 / 9$ & & degree C \\
\hline Ambient temperature & & degree $\mathrm{F}$ & $\left.{ }^{\circ} \mathrm{F}-32\right) \times 5 / 9$ & & $\mathrm{~m} / \mathrm{min}$ \\
\hline Line speed & & $\mathrm{ft} / \mathrm{min}$ & 0.3048 & & $\mathrm{~g} / \mathrm{m} 2$ \\
\hline Coating weight & & $\mathrm{oz} / \mathrm{ft} 2$ & 305.15 & & $\mathrm{~m}$ \\
\hline Strip width & & $\mathrm{ft}$ & 0.3048 & & $\mathrm{~m}$ \\
\hline Strip thickness & & $\mathrm{ft}$ & 0.3048 & & $\mathrm{~m}$ \\
\hline
\end{tabular}

Figure 45: Input parameters 


\begin{tabular}{|c|c|c|c|}
\hline 1. Heat loss from surface of the Pot & & & \\
\hline \multicolumn{4}{|l|}{ Emissivity } \\
\hline Stephen Boltzmann & $\mathrm{Btu} / \mathrm{h} \cdot \mathrm{ft}^{2} \cdot{ }^{\circ} \mathrm{R}^{4}$ & & $\mathrm{~W} / \mathrm{m} 2 .{ }^{\circ} \mathrm{K} 4$ \\
\hline Radiation heat loss (surface) & Btu/hr & .29 & w \\
\hline Convection heat loss (surface) & Btu/hr & .29 & w \\
\hline Heat loss from surface of the Pot & Btu/hr & .29 & w \\
\hline \multicolumn{4}{|l|}{ 2. Heat loss through the bottom of the Pot } \\
\hline Area of bottom & $\mathrm{ft} 2$ & 0.093 & $\mathrm{~m} 2$ \\
\hline Temperature of pot & degree $\mathrm{F}$ & $\left({ }^{\circ} \mathrm{F}-32\right) \times 5 / 9$ & degree $\mathrm{C}$ \\
\hline Temperature of bottom of the pot & degree $\mathrm{F}$ & $\left({ }^{\circ} \mathrm{F}-32\right) \times 5 / 9$ & degree C \\
\hline Insulation 1 thickness & $\mathrm{ft}$ & 0.3048 & \\
\hline Thermal conductivity of insulation 1 & Btu/hr.ft.F & 1.7307 & $\mathrm{~W} / \mathrm{mC}$ \\
\hline Insulation 2 thickness & $\mathrm{ft}$ & 0.3048 & $\mathrm{~m}$ \\
\hline Thermal conductivity of insulation 2 & Btu/hr.ft.F & 1.7307 & $\mathrm{~W} / \mathrm{mC}$ \\
\hline Thickness of pot material & $\mathrm{ft}$ & 0.3048 & $\mathrm{~m}$ \\
\hline Thermal conductivity of pot material & Btu/hr.ft.F & 1.7307 & $\mathrm{~W} / \mathrm{mC}$ \\
\hline Heat loss through the bottom of the Pot & Btu/hr & 0.29 & w \\
\hline \multicolumn{4}{|l|}{ 3. Heat loss through walls of the Pot } \\
\hline Total wall area & $\mathrm{ft} 2$ & 0.093 & $\mathrm{~m} 2$ \\
\hline Temperature of walls & degree $\mathrm{F}$ & $\left({ }^{\circ} \mathrm{F}-32\right) \times 5 / 9$ & degree $\mathrm{C}$ \\
\hline Heat convection coefficient & Btu/hr.ft2.F & 5.6786 & $\mathrm{~W} / \mathrm{m} 2 \mathrm{C}$ \\
\hline Convection heat loss & Btu/hr & .29 & W \\
\hline \multicolumn{4}{|l|}{ Emissivity } \\
\hline Radiation heat loss & $\mathrm{Btu} / \mathrm{hr}$ & .29 & W \\
\hline Heat loss through the walls of the Pot & Btu/hr & .29 & w \\
\hline
\end{tabular}

Figure 46: Computation model

\begin{tabular}{|c|c|c|c|}
\hline \multicolumn{4}{|l|}{ 4. Heat conduction (absorption) from strip } \\
\hline Thickness of strip & $\mathrm{ft}$ & 0.3048 & $\mathrm{~m}$ \\
\hline Width of strip & $\mathrm{ft}$ & 0.3048 & $m$ \\
\hline Density of strip & $\mathrm{lb} / \mathrm{ft} 3$ & 16.02 & $\mathrm{~kg} / \mathrm{m} 3$ \\
\hline Line speed & $\mathrm{ft} / \mathrm{min}$ & 0.3048 & $\mathrm{~m} / \mathrm{min}$ \\
\hline Strip temperature at entry & degree $\mathrm{F}$ & $\left({ }^{\circ} \mathrm{F}-32\right) \times 5 / 9$ & degree $\mathrm{C}$ \\
\hline Strip temperature at exit & degree $\mathrm{F}$ & $\left({ }^{\circ} \mathrm{F}-32\right) \times 5 / 9$ & degree $\mathrm{C}$ \\
\hline Heat conduction (absorption) from the strip & Btu/hr & .29 & w \\
\hline \multicolumn{4}{|l|}{ 5. Heat required to melt ingots and } \\
\hline \multicolumn{4}{|l|}{ maintain pot temperature } \\
\hline Amount of pure $\mathrm{Zn}$ ingot added & $\mathrm{lbs} / \mathrm{hr}$ & 0.4535 & $\mathrm{~kg} / \mathrm{hr}$ \\
\hline Amount of $\mathrm{Al}$ in $\mathrm{Al}-\mathrm{Zn}$ alloy ingot added & $\mathrm{lbs} / \mathrm{hr}$ & 0.4535 & $\mathrm{~kg} / \mathrm{hr}$ \\
\hline Amount of $\mathrm{Zn}$ in $\mathrm{Al}-\mathrm{Zn}$ alloy ingot added & $\mathrm{lbs} / \mathrm{hr}$ & 0.4535 & $\mathrm{~kg} / \mathrm{hr}$ \\
\hline Heat required to melt ingots & Btu/hr & .29 & w \\
\hline \multicolumn{4}{|l|}{ 6. Heat loss due to air knife cooling effect } \\
\hline Heat convection coefficient & Btu/hr.ft2.F & 5.6786 & $\mathrm{~W} / \mathrm{m}$.degree $\mathrm{C}$ \\
\hline Air knife height & $\mathrm{ft}$ & 0.3048 & $\mathrm{~m}$ \\
\hline Cooling length & $\mathrm{ft}$ & 0.3048 & $\mathrm{~m}$ \\
\hline Strip width & $\mathrm{ft}$ & 0.3048 & $\mathrm{~m}$ \\
\hline Wiping gas temperature & degree $\mathrm{F}$ & $\left({ }^{\circ} \mathrm{F}-32\right) \times 5 / 9$ & degree $\mathrm{C}$ \\
\hline Pot surface temperature & degree $\mathrm{F}$ & $\left({ }^{\circ} \mathrm{F}-32\right) \times 5 / 9$ & degree $\mathrm{C}$ \\
\hline Air knife heat loss & Btu/hr & 0.29 & w \\
\hline
\end{tabular}

Figure 47: Computation model (cont) 


\begin{tabular}{|l|c|c|c|c|c|}
\hline 7. Zinc coating heat loss & & & & \\
\hline Coating weight & & $\mathrm{oz} / \mathrm{ft} 2$ & 305.15 & $\mathrm{~g} / \mathrm{m} 2$ \\
\hline Line speed & & $\mathrm{ft} / \mathrm{min}$ & 0.3048 & $\mathrm{~m} / \mathrm{min}$ \\
\hline Strip width & & $\mathrm{ft}$ & 0.3048 & $\mathrm{~m}$ \\
\hline \multicolumn{1}{|c|}{ Heat loss from zinc coating } & & $\mathrm{Btu} / \mathrm{hr}$ & 0.29 & & $\mathrm{~W}$ \\
\hline
\end{tabular}

\begin{tabular}{|c|c|c|c|}
\hline \multicolumn{4}{|l|}{ 8. Dross removal heat loss } \\
\hline Total amount of dross & $\mathrm{Ibs} / \mathrm{hr}$ & 0.4535 & $\mathrm{~kg} / \mathrm{hr}$ \\
\hline Average temperature of the dross & degree $\mathrm{F}$ & $\left({ }^{\circ} \mathrm{F}-32\right) \times 5 / 9$ & degree C \\
\hline Percentage of Fe in dross & $\%$ & & $\%$ \\
\hline Percentage of $\mathrm{Zn}$ in dross & $\%$ & & $\%$ \\
\hline Heat loss from dross removal & Btu/hr & 0.29 & w \\
\hline
\end{tabular}

C. Summary

Total heat loss during production

\begin{tabular}{|c|l|c|c|c|}
\hline Total heat loss during production & \multicolumn{1}{l|}{} \\
\hline Main Pot & & MMBtu/hr & 290 & \\
\hline Premelt-pot & & MMBtu/hr & 290 & \\
\hline Downtime (Main Pot) & & MMBtu/hr & 290 & \\
\hline & & & & \\
\hline Heating capacity & & kW & & \\
\hline Main Pot & & kW & & MMBtu/hr \\
\hline Premelt & & & MMBtu/hr \\
\hline
\end{tabular}

\section{Figure 48: Computation model (cont)}

\begin{tabular}{|l|l|l|l|}
\hline \multicolumn{2}{|l|}{} & & \\
\hline 1 & Heat loss from the surface & & Btu/hr \\
\hline 2 & Heat loss through the bottom & & $\mathrm{Btu} / \mathrm{hr}$ \\
\hline 3 & Heat loss through the walls & $\mathrm{hr}$ \\
\hline 4 & Heat conduction (absorption) from the steel strip & & $\mathrm{Btu}$ \\
\hline 5 & Heat required to melt added ingots and & & $\mathrm{Btu} / \mathrm{hr}$ \\
\hline & maintain the zinc bath temperature & & $\mathrm{Btu} / \mathrm{hr}$ \\
\hline 6 & Heat loss due to air knife cooling effect & & $\mathrm{Btu} / \mathrm{hr}$ \\
\hline 7 & Heat loss from zinc coating & & $\mathrm{Btu} / \mathrm{hr}$ \\
\hline 8 & Heat loss from dross removal & & $\mathrm{Btu} / \mathrm{hr}$ \\
\hline & \multicolumn{1}{|c|}{ Total loss } & \\
\hline & \multicolumn{1}{|l}{} & \\
\hline & Main pot & & $\mathrm{MMBtu} / \mathrm{hr}$ \\
\hline & Pre meltpot & & $\mathrm{MMBtu} / \mathrm{hr}$ \\
\hline & Downtime (Main pot) & $\mathrm{MMBtu} / \mathrm{hr}$ \\
\hline
\end{tabular}

Figure 49: Summary worksheet screenshot

\begin{tabular}{|l|l|l|l|}
\hline \multicolumn{3}{|c|}{ Main pot (with a pre-melt pot) } \\
\hline \multicolumn{2}{|c|}{ IN (MMBTu/hr) } & \multicolumn{2}{c|}{ OUT (MMBtu/hr) } \\
\hline Strip & & Strip & \\
\hline Electrical & & Coating heat loss & \\
\hline Ingots & & Dross & \\
\hline & & Air knife & \\
\hline & & Surface & \\
\hline & & Walls & \\
\hline & & Bottom & \\
\hline & & Unaccounted heat & \\
\hline & & & \\
\hline & & & \\
\hline Load factor & & & \\
\hline
\end{tabular}

\begin{tabular}{|l|l|l|l|}
\hline \multicolumn{4}{|c|}{ Main pot (with no pre-melt pot) } \\
\hline \multicolumn{1}{|c|}{ IN (MMBT/hr) } & \multicolumn{2}{c|}{ OUT (MMBtu/hr) } \\
\hline Strip & & Strip & \\
\hline Electrical & & Coating heat loss & \\
\hline Ingots & & Dross & \\
\hline & & Air knife & \\
\hline & & Surface & \\
\hline & & Walls & \\
\hline & & Bottom & \\
\hline & & Unaccounted heat & \\
\hline & & & \\
\hline & & & \\
\hline Load factor & & & \\
\hline
\end{tabular}

Figure 50: Heat balance worksheet screenshot 


\begin{tabular}{|c|c|l|l|c|l|}
\hline \multicolumn{3}{|c|}{ IN (Ibs/hr) } & \multicolumn{3}{c|}{ OUT (Ibs/hr) } \\
\hline Strip & Fe & & Strip & Fe & \\
\hline & & & & & \\
\hline Ingots & & & Dross & & \\
\hline & Pure Zn & & & Al & \\
\hline & Al in Al-Zn & & & Fe & \\
\hline & Zn in Al-Zn & & & Zn & \\
\hline & & & & & \\
\hline & & & Coating & Zn & \\
\hline Total & & & & & \\
\hline
\end{tabular}

Figure 51: Mass balance

\begin{tabular}{|c|c|c|c|c|c|c|c|c|c|}
\hline & & & & & & & & & \\
\hline & Temperature & & degree $\mathrm{F}$ & & degree $\mathrm{K}$ & & & & \\
\hline & & & & & & & & & \\
\hline & & Atomic & $\%$ & $\mathrm{lbs} / \mathrm{hr}$ & kg.mole/hr & Mcal $/ \mathrm{kg} \cdot \mathrm{mol}$ & $\mathrm{Mcal} / \mathrm{hr}$ & Convert to & MMBtu/hr \\
\hline & $\mathrm{Fe}$ & 55.85 & & & & & & & \\
\hline & $\mathrm{Al}$ & 26.98 & & & & & & & \\
\hline & $\mathrm{Zn}$ & 65.38 & & & & & & & \\
\hline Sensible heat of & Dross & & & & & & & & \\
\hline
\end{tabular}

Figure 52: Dross worksheet screenshot

\begin{tabular}{|c|c|c|c|c|c|c|c|c|c|c|}
\hline & & & & & & \multicolumn{2}{|c|}{ Atomic mass } & & & \\
\hline Ingot initial temperature & & degree $\mathrm{F}$ & & degree $\mathrm{K}$ & & $\mathrm{Zn}$ & 65.38 & & & \\
\hline \multirow[t]{4}{*}{ Ingot final temperature } & & degree $\mathrm{F}$ & & degree $\mathrm{K}$ & & Al & 26.98 & & & \\
\hline & & & & & & & & & & \\
\hline & & & & & & & & & & \\
\hline & Ibs/hr & $\mathrm{kg} \cdot \mathrm{mol} / \mathrm{hr}$ & $\begin{array}{c}\Delta \mathrm{H} \text { before } \\
\text { melting } \\
\text { ( } \mathrm{Mcal} / \mathrm{kg} \cdot \mathrm{mol} \text { ) }\end{array}$ & $\mathrm{Mcal} / \mathrm{hr}$ & $\begin{array}{c}\Delta \mathrm{H} \text { after } \\
\text { melting } \\
(\mathrm{Mcal} / \mathrm{kg} \cdot \mathrm{mol})\end{array}$ & Mcal/hr & $\begin{array}{c}\text { Difference } \\
\text { in delta } \mathrm{H}\end{array}$ & $\begin{array}{l}\text { Difference } \\
\text { in } \mathrm{Mcal} / \mathrm{hr}\end{array}$ & $\begin{array}{c}\text { Convert } \\
\text { to }\end{array}$ & $\begin{array}{c}\text { MmBtu/ } \\
\mathrm{hr}\end{array}$ \\
\hline \multicolumn{11}{|l|}{ Pure Zn } \\
\hline \multicolumn{11}{|l|}{$\mathrm{Al}$ in $\mathrm{Al}-\mathrm{Zn}$ alloy } \\
\hline \multicolumn{11}{|l|}{$\mathrm{Zn}$ in $\mathrm{Al}-\mathrm{Zn}$ alloy } \\
\hline & & & & & & & & & & \\
\hline Tota amount of heat required & & & & & & & & & & \\
\hline
\end{tabular}

Figure 53: Ingot worksheet screenshot

\begin{tabular}{|c|c|c|c|c|}
\hline & & & & \\
\hline Line speed & & $\mathrm{ft} / \mathrm{min}$ & & \\
\hline Density & & $\mathrm{lbs} / \mathrm{ft} 3$ & & \\
\hline Width & & $\mathrm{ft}$ & & \\
\hline Gauge & & $\mathrm{ft}$ & & \\
\hline Strip entry temperature & & degree $\mathrm{F}$ & & degree $\mathrm{K}$ \\
\hline Strip exit temperature & & degree $\mathrm{F}$ & & degree $\mathrm{K}$ \\
\hline Mass flow rate & & $\mathrm{lbs} / \mathrm{hr}$ & & \\
\hline Moles & & $\mathrm{kg}-\mathrm{mol} / \mathrm{hr}$ & & \\
\hline$\Delta \mathrm{H}$ at entry & & $\mathrm{Mcal} / \mathrm{kg} \cdot \mathrm{mol}$ & & \\
\hline Potential energy & & $\mathrm{Mcal} / \mathrm{hr}$ & & $\mathrm{MMBtu} / \mathrm{hr}$ \\
\hline$\Delta \mathrm{H}$ at exit & & $\mathrm{Mcal} / \mathrm{kg} \cdot \mathrm{mol}$ & & \\
\hline Potential energy & & $\mathrm{Mcal} / \mathrm{hr}$ & & $\mathrm{MMBtu} / \mathrm{hr}$ \\
\hline Difference in potential energy & & $\mathrm{Mcal} / \mathrm{hr}$ & & \\
\hline Heat absorbed/conducted & & $\mathrm{MMBtu} / \mathrm{hr}$ & & \\
\hline
\end{tabular}

Figure 54: Strip worksheet screenshot 


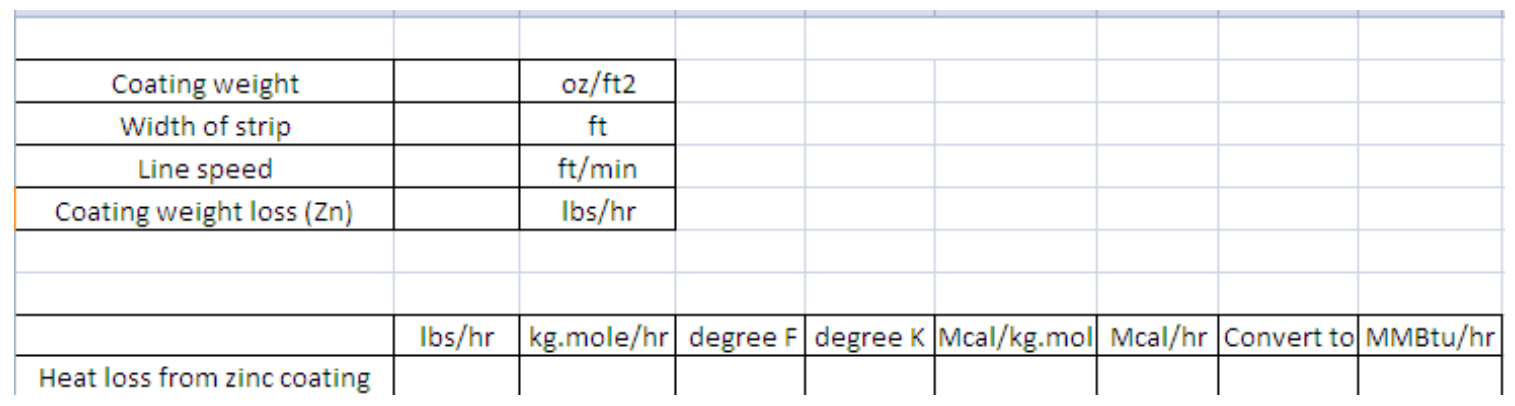

Figure 55: Zinc coating worksheet screenshot

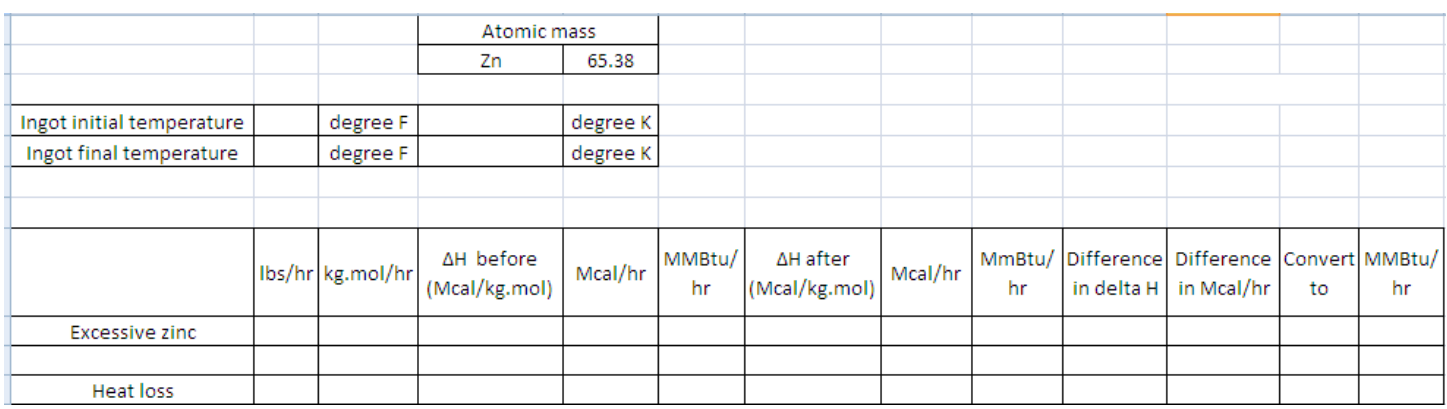

Figure 56: Excessive zinc

\begin{tabular}{|c|c|c|c|c|c|}
\hline \multicolumn{5}{|c|}{ Heat Content for Metals } \\
\cline { 2 - 7 } & \multicolumn{5}{|c|}{ Metals } \\
\hline \multirow{4}{*}{} & Fe & \multicolumn{2}{|c|}{$\mathrm{Al}$} & \multicolumn{2}{c|}{$\mathrm{Zn}$} \\
\hline & $0-1033 \mathrm{~K}$ & $0-931.7 \mathrm{~K}>931.7 \mathrm{~K}$ & $0-692.7 \mathrm{~K}>692.7 \mathrm{~K}$ \\
\hline & $\alpha$ & cryst & liq & cryst & liq \\
\hline & 3.37 & 4.94 & 7 & 5.35 & 7.5 \\
\hline $\mathrm{a}$ & 0.00355 & 0.00148 & 0 & 0.0012 & 0 \\
\hline $\mathrm{b}$ & -0.0000043 & 0 & 0 & 0 & 0 \\
\hline $\mathrm{c}$ & -1176 & -1605 & 330 & -1702 & -850 \\
\hline $\mathrm{d}$ & & & & & \\
\hline & & & & & \\
\hline
\end{tabular}

Figure 57: Reference worksheet screenshot 


\begin{tabular}{|l|l|}
\hline Heat convection coefficient calculation & \\
\hline tempfilm & \\
\hline $\mathrm{k}$ & \\
\hline $\mathrm{g}$ & \\
\hline $\mathrm{L}$ & \\
\hline RaL & \\
\hline Nusselt & \\
\hline HeatCoef & \\
\hline
\end{tabular}

Figure 58: Background worksheet screenshot

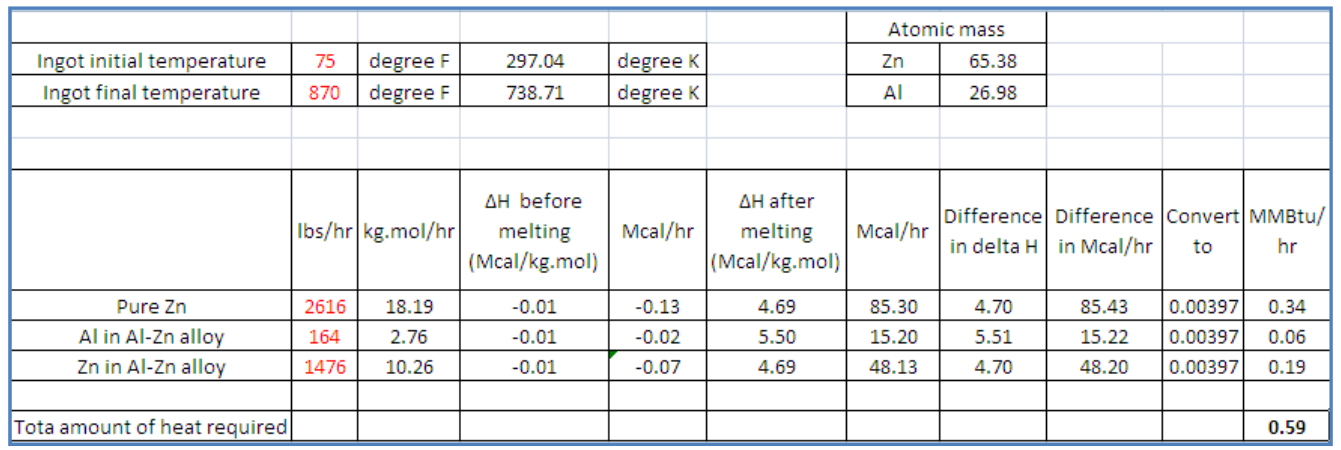

Figure 59: Ingot worksheet result screenshot

\begin{tabular}{|c|c|c|c|c|c|c|c|c|c|}
\hline & & & degree F & & & & & & \\
\hline & Temperature| & $5 / 2$ & degree + & $5 / 3.15$ & degree K & & & & \\
\hline & & & & & & & & & \\
\hline & & Atomic & $\%$ & $\mathrm{lbs} / \mathrm{hr}$ & kg.mole/hr & Mcal $/ \mathrm{kg} . \mathrm{mol}$ & $\mathrm{Mcal} / \mathrm{hr}$ & \begin{tabular}{|l|} 
Convert to \\
\end{tabular} & MMBtu/hr \\
\hline & $\mathrm{Fe}$ & 55.85 & 2 & 6 & 0.05 & 1.92 & 0.09 & 0.00397 & \\
\hline & $\mathrm{Al}$ & 26.98 & 3 & 9 & 0.15 & 1.71 & 0.26 & 0.00397 & \\
\hline & $\mathrm{Zn}$ & 65.38 & 95 & 285 & 1.98 & 1.76 & 3.48 & 0.00397 & \\
\hline Sensible heat of & Dross & & 1 & 300 & & & 3.84 & 0.00397 & 0.02 \\
\hline
\end{tabular}

Figure 60: Dross worksheet result screenshot

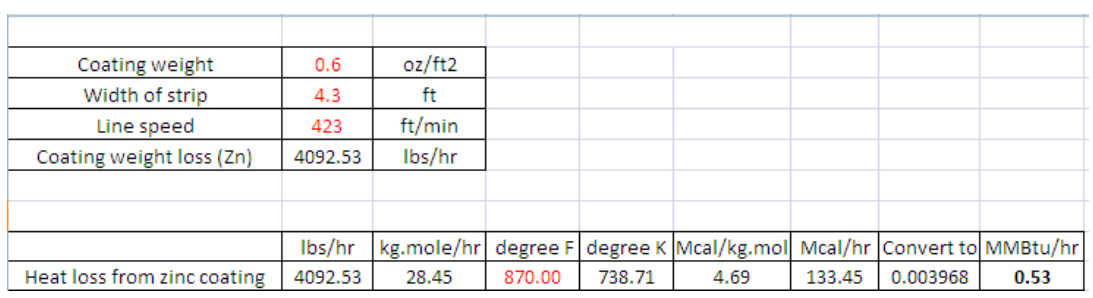

Figure 61: Zinc coating worksheet result screenshot 


\begin{tabular}{|c|c|c|c|c|c|c|c|c|c|c|c|c|}
\hline & & & \multicolumn{2}{|c|}{ Atomic mass } & & & & & & & & \\
\hline & & & $\mathrm{Zn}$ & 65.38 & & & & & & & & \\
\hline & & & & & & & & & & & & \\
\hline Ingot initial temperature & 870 & degree $\mathrm{F}$ & 738.71 & degree $\mathrm{K}$ & & & & & & & & \\
\hline \multirow[t]{4}{*}{ Ingot final temperature } & 700 & degree $\mathrm{F}$ & 644.26 & degree $\mathrm{K}$ & & & & & & & & \\
\hline & & & & & & & & & & & & \\
\hline & & & & & & & & & & & & \\
\hline & Ibs/hr & $\mathrm{kg} \cdot \mathrm{mol} / \mathrm{hr}$ & $\begin{array}{c}\Delta \mathrm{H} \text { before } \\
\text { (Mcal } / \mathrm{kg} \cdot \mathrm{mol})\end{array}$ & $\mathrm{Mcal} / \mathrm{hr}$ & $\begin{array}{c}\text { MMBtu/ } \\
\mathrm{hr}\end{array}$ & $\begin{array}{c}\Delta \mathrm{H} \text { after } \\
\text { (Mcal } / \mathrm{kg} \cdot \mathrm{mol})\end{array}$ & $\mathrm{Mcal} / \mathrm{hr}$ & $\begin{array}{c}\text { MmBtu/ } \\
\mathrm{hr}\end{array}$ & \begin{tabular}{|c|} 
Difference \\
in delta $\mathrm{H}$
\end{tabular} & $\begin{array}{l}\text { Difference } \\
\text { in } \mathrm{Mcal} / \mathrm{hr}\end{array}$ & $\begin{array}{c}\text { Convert } \\
\text { to }\end{array}$ & $\begin{array}{c}\text { MMBtı } \\
\mathrm{hr}\end{array}$ \\
\hline Excessive zinc & 1,000 & 6.95 & 4.69 & 32.61 & 0.1294 & 3.98 & 27.68 & 0.11 & -0.71 & -4.92 & 0.00397 & -0.02 \\
\hline & & & & & & & & & & & & \\
\hline Heat loss & & & & & 0.129 & & & 0.11 & & & & 0.02 \\
\hline
\end{tabular}

Figure 62: Excessive zinc result screenshot

\begin{tabular}{|c|c|c|c|c|}
\hline & & & & \\
\hline Line speed & 423 & $\mathrm{ft} / \mathrm{min}$ & & \\
\hline Density & 490 & $\mathrm{lbs} / \mathrm{ft} 3$ & & \\
\hline Width & 4.3 & $\mathrm{ft}$ & & \\
\hline Gauge & 0.00208 & $\mathrm{ft}$ & & \\
\hline Strip entry temperature & 863 & degree $\mathrm{F}$ & 735 & degree $\mathrm{K}$ \\
\hline Strip exit temperature & 870 & degree $\mathrm{F}$ & 739 & degree $\mathrm{K}$ \\
\hline Mass flow rate & 111,229 & $\mathrm{lbs} / \mathrm{hr}$ & & \\
\hline Moles & 905 & $\mathrm{~kg}-\mathrm{mol} / \mathrm{hr}$ & & \\
\hline$\Delta \mathrm{H}$ at entry & 3.22 & $\mathrm{Mcal} / \mathrm{kg} \cdot \mathrm{mol}$ & & \\
\hline Potential energy & 2912.38 & $\mathrm{Mcal} / \mathrm{hr}$ & 11.56 & $\mathrm{MMBtu} / \mathrm{hr}$ \\
\hline$\Delta \mathrm{H}$ at exit & 3.25 & $\mathrm{Mcal} / \mathrm{kg} \cdot \mathrm{mol}$ & & \\
\hline Potential energy & 2942.66 & $\mathrm{Mcal} / \mathrm{hr}$ & 11.68 & $\mathrm{MMBtu} / \mathrm{hr}$ \\
\hline Difference in potential energy & 30.28 & $\mathrm{Mcal} / \mathrm{hr}$ & & \\
\hline Heat absorbed/conducted & $\mathbf{0 . 1 2}$ & $\mathbf{M M B t u} / \mathrm{hr}$ & & \\
\hline
\end{tabular}

\section{Figure 63: Strip worksheet result screenshot}

\begin{tabular}{|l|r|}
\hline Heat convection coefficient calculation & \\
\hline tempfilm & 230.83 \\
\hline $\mathrm{k}$ & 0.04 \\
\hline $\mathrm{g}$ & 8.12 \\
\hline $\mathrm{L}$ & 2.98 \\
\hline RaL & 268552355 \\
\hline Nusselt & 208.50 \\
\hline HeatCoef & 9.38 \\
\hline
\end{tabular}

Figure 64: Background worksheet result screenshot

\begin{tabular}{|c|c|c|c|c|c|}
\hline \multicolumn{5}{|c|}{} & \multicolumn{5}{|c|}{ Heat Content for Metals } \\
\cline { 2 - 6 } & \multicolumn{5}{|c|}{ Metals } \\
\cline { 2 - 6 } & $\mathrm{Fe}$ & \multicolumn{2}{|c|}{$\mathrm{Al}$} & \multicolumn{2}{c|}{$\mathrm{Zn}$} \\
\hline & $0-1033 \mathrm{~K}$ & $0-931.7 \mathrm{~K}>931.7 \mathrm{~K}$ & $0-692.7 \mathrm{~K}>692.7 \mathrm{~K}$ \\
\cline { 2 - 6 } & $\alpha$ & cryst & liq & cryst & liq \\
\hline $\mathrm{n}$ & 3.37 & 4.94 & 7 & 5.35 & 7.5 \\
\hline $\mathrm{a}$ & 0.00355 & 0.00148 & 0 & 0.0012 & 0 \\
\hline $\mathrm{c}$ & -0.0000043 & 0 & 0 & 0 & 0 \\
\hline $\mathrm{d}$ & -1176 & -1605 & 330 & -1702 & -850 \\
\hline
\end{tabular}

Figure 65: Reference worksheet result screenshot 